SERI/TR-231-1947

UC Category: 61a

DE83011976

\title{
Algae from the Arid Southwestern United States: An Annotated Bibliography
}

\section{A Subcontract Report}

W. H. Thomas

S. R. Gaines

Institute of Marine Resources

Scripps Institute of Oceanography University of California, San Diego

La Jolla, California 92092

June 1983

Prepared under Subcontract No. XK-09111-1

SERI Technical Monitor: M. Lowenstein

Solar Energy Research Institute A Division of Midwest Research Institute

1617 Cole Boulevard

Golden, Colorado 80401

Prepared for the

U.S. Department of Energy

Contract No. EG-77-C-01-4042 
Printed in the United States of America Available from:

National Technical Information Service

U.S. Department of Commerce

5285 Port Royal Road

Springfield, VA 22161

Price:

Microfiche $\$ 4.50$

Printed Copy $\$ 14.50$

\section{NOTICE}

This report was prepared as an account of work sponsored by the United States Government. Neither the United States nor the United States Department of Energy, nor any of their employees, nor any of their contractors, subcontractors, or their employees, makes any warranty, express or implied, or assumes any legal liability or responsibility for the accuracy, completeness or usefulness of any information, apparatus, product or process disclosed, or represents that its use would not infringe privately owned rights. 


\section{FOREWORD}

This report is an annotated bibliography compiled by Scripps Institute of Oceanography for the Solar Energy Research Institute (SERI) under Subcontract XK-09111-1, using funds provided by the Biomass Energy Technology Divison of the Department of Energy. This report is provided to the research community in the hope that it will be an invaluable tool for future research in field collection and identification of microalgae in desert environments.
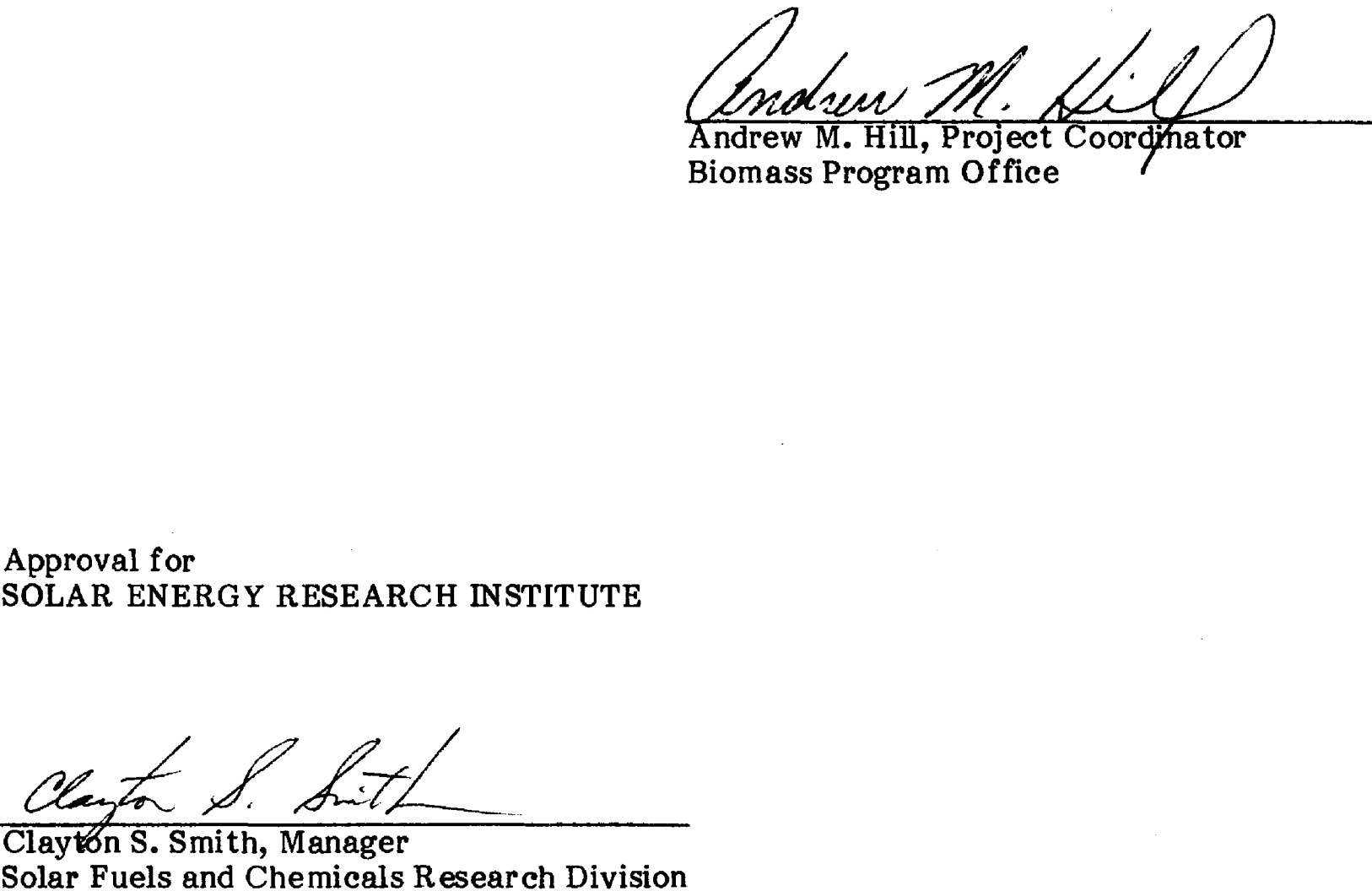


\section{PREFACE AND ACKNOWLEDGEMENTS}

As supplies of non-renewable fuels coil, coal, gas, uranium, thorium, etc.) become depleted, it will be desirable to utilize renewable energy sources. Such sources include biomass fiom microalgae. These plants capture solar energy through photosynthesis and are generally much more efficient in using sunlight than higher plants. For growing microalgae on a large scale, abundant land areas, sunlight, and water resources are required.

The southwestern desert areas of the United 5 tates meet these requirements, especially if saline waters are used. It is logical to isolate and utilize algae from this region for application to outdoor pond culture, since such algae will probably be able to withstand extremes of light intensity, 5alinity and temperature better than algae isolated from other enviroments.

This report is an annotated bibliography of algaefrom the southwestern United states. It was prepared in anticipation of increased efforts to isolate desert algae and study their yields and photosynthetic efficiencies in the laboratory prior to setting up outdoor pond cultures in the desert.

We are grateful to numerous individuals who helped us track down pertinent published literature and/or supplied unpublished reports. Personnel from the U.S. Bureau of Land Management, National Park Service, Bureau of Reclamation, and Environmental Protection Agency, as weIl as several investigators from colleges and universities, were particularly helptul. We also appreciate the aid of Ms. Susan Star, of the scripps Institution of Oceanography Library, and Mr. Dan Gittings, of the U.S.

National Marine Eisheries Service Southwest Fisheries Center Library, who aided in computer searching of the literature and obtained many papers by interlibrary loans. Mr. Don L.R. Seibert and Mr. John Brown helped with computer programming. Acquisition of microcomputer equipment was made possible by Grant No. OCE-8117399 from the National Science Foundation and by a grant from the Bio-Energy Council. 


\section{SUMMARY}

Desert algae are attractive biomass producers for capturing solar energy through photosynthesis of organic matter. They are probably capable of higher yields and efficiencies of light utilization than higher plants, and are already adapted to extremes of sunlight intensity, salinity and temperature such as are found in the desert.

This report consists of an annotated bibliography of the literature on algae from the arid southwestern United states. It was prepared in anticipation of efforts to isolatedesert algae and study their yields in the laboratory. These steps are necessary prior to setting up outdoor algal culture ponds Desert areas are attractive for such applications because land, sunlight, and, to some extent, water resources are abundant there.

The bibliography was prepared by computer and citation searches of the published literature plus contact by letter and telephone with various agencies and individuals who could supply additional reports and references. The references are listed by the pertinent state (Arizona, California, Nevada, etc.). Listings for each state or area include papers that are directly about algae plus separate references to the aquatic or soil habitats in which the algae occur. The listings on algae are reasonably complete. The listings or habitats (i.e. water resource and water chemistry papers) are less complete but provide leads into the pertinant geological, hydrological, and chemical literature which may be useful to the non-biologist. Often a given reference may be listed more than once since it describes algae or habitats occurcing in more than one state or area.

Generally, for each reference the author's abstract is included as an annotation. In some cases, however, we have written an abstract. A few papers concerning algal habitats are not abstracted. These papers were not seen. but are included for the possible interest of the reader. Keywords are provided for each reference. The first author of the paper is always the ficst keyword, followed by the state and then the water type (saline or freshwater). "Saline" refers to waters having>looo mg/liter total dissolved solids. A dictionary of keywords is provided and al of these teferences plus their abstracts have been entered onto microcomputer disk. We have a computer program for searching this bibliography by keywords or combinations thereof. Computer searches can be performed for any interested reader.

In preparing this bibliography and reading al of these papers, we have reached the following conclusions about desert algae and the literature concerning them: 
- Most papers just list the occurrences of various species.

- Less has been published on the physiology and ecology of these algae and the ecological remarks are often speculative.

- There is a wealth of data on the chemistry of waters in which these algae occur.

- The number of species found (diversity) decreases as the total dissolved solids ( 5 alinity) increases. Thus the Colorado River may contain >100 taxa while Mono Lake or the Great salt lake contain<10 taxa.

- Representatives of all ciasses of microalgae occur in the arid Southwest. Blue-green algae, followed by green a $1 \mathrm{gae}$ and diatoms, are most of ten reported.

- Habitats include soil (and algal crusts), seaps, snowfields, pools, ponds, lakes, streams, and rivers. 


\section{TABLE OF CONTENTS}

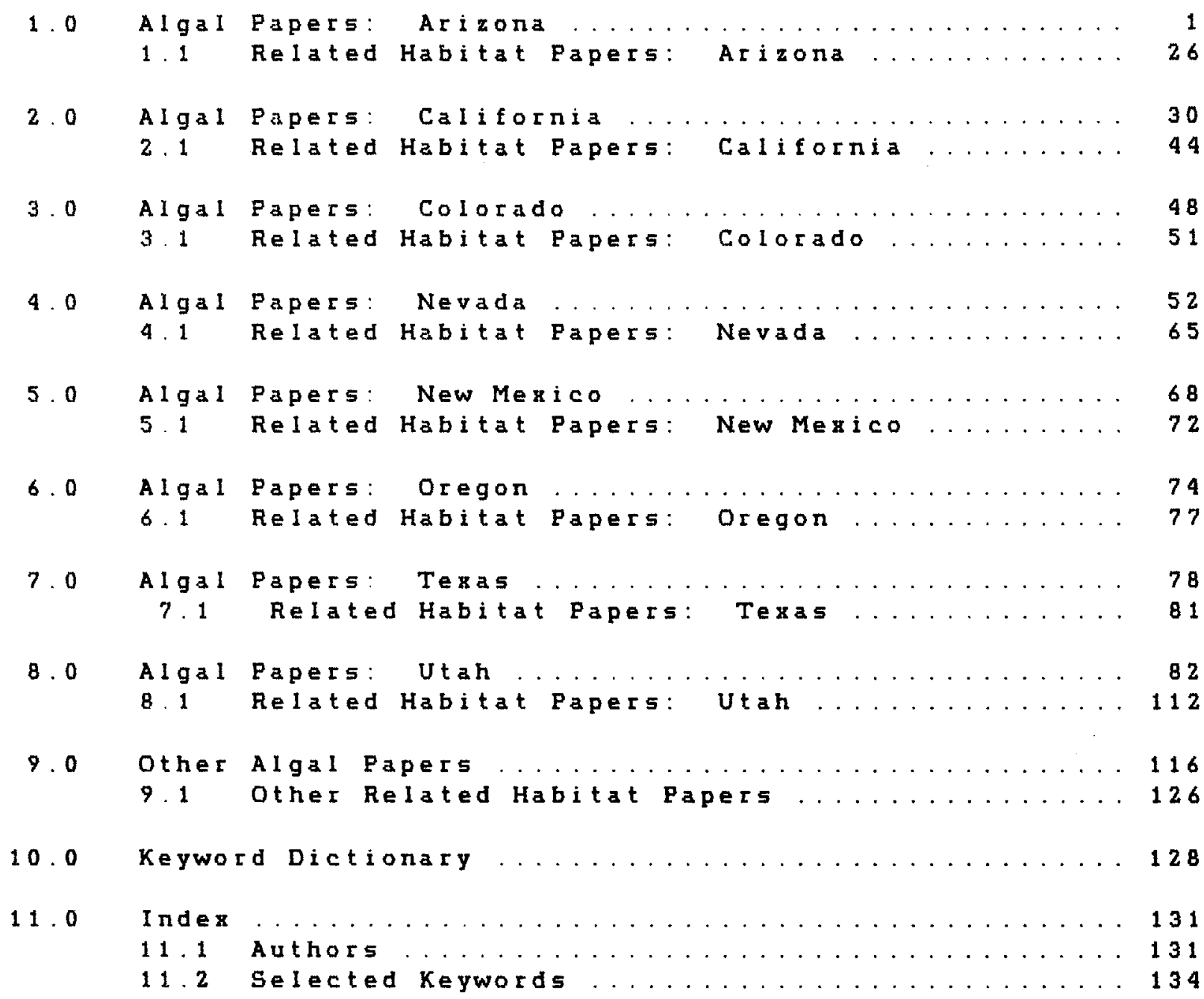


SECTION 1 . O

ALGAL PAPERS: ARIZONA

BIinn, D.W. and Button, K.S. 1973. The effect of temperature on parasitism of Panorina sp. by Dangeardia mammilata $B$. Schroeder in an Arizona mountain lake. J. Phycol.9: $323-326$.

A chytridiaceous fungus, Dangeardia mammillata, was found to be selectively parasitizing the volvocalean pandorina sp. in a shallow eutrophic mountain lake northern Arizona. Population estimates of infected algal colonies reached $68 \%$ during epidemic periods (Feb.-Mar.). Selected physico-chemical parameters were measured during the infection period, with temperature found to be the most important factor in regulating chytrid parasitism. Infection only occurred at temperatures below 17 c in the tield, and infection only at low temperatures was confirmed by laboratory investigations. Other parameters showed no apparent relationship with the chytrid-algal association. The roles of photosynthetic enudates are also discussed in regulation of chytrid parasitism.

BIingl Arizonal freshwater/ lakel green algael

BIinn, D.W. and Penton, M. 1981. The diatom flora of the lower Chevelon Creek area of Arizona: An inland brackish water system. Southwest. Nat. 26:311-324.

Diatom species found in this area are listed and some are illustrated. Some analytical data on ionic composition of these waters are presented. Some of these species are typically "marine" or "estuarine."

Bling/ Arizona/ saline/ stream/ pond/ salt marsh/springl diatom/ chemistry/ species list/ illustrations/

BIinn, D.W. and Stein, J.R. 1970. Distribution and tanonomic reappraisal of Ctenocladus (Chlorophyceae: Chaetophorales). J. Phycol. 6: 101-105.

The distribution of the rare filamentous green alga Ctenocladus Borzi was examined on a world-wide basis. All the collection sites are restricted to specific inland habitats. Most of these locations are in arid regions of North America with a tew scattered sites in Peru, Sicily, and siberia. This alga has been referred to 2 genera, either ctenocladus or Lochmiopsis Woronochin \& Popova, for the past 45 years. Based on tield observations, laboratory cultures, and herbarium material, 
Lochmiopsis is considered synonymous with ctenocladus. The response of vegetative celi dimensions to seasonal changes (i.e., osmotic potential and temperature) in 3 saline habitats in British Columbia was also investigated. Results from the study, along with laboratory dilutions of natural saline waters, showed that cell dimensions are not valid criteria for separating species of ctenocladus as proposed by some authors. Consequently Ctenocladus is considered a morotypic genus with physiological variants responding to seasonal environmental conditions. (In North America this alga has been collected at Mono Lake and Borax Lake, California; Green Fond and Red Fond, Arizona; Abert Lake, Oregon and at several locations in British Columbia. Isolates from the latter locations are illustrated).

Blinn/ British Columbia/ Californial Oregon/ Arizona/ Nevadal salinel lake/ pond/ green algael taxonomy/ illustrations/

Busch, D.E. 1979. The patchiness of diatom distribution in a desert stream. J. Ariz. - Nev. Acad. Sci. 14:43-46.

The correspondence between the visual patchiness and the distribution of diatoms in a desert stream is evaluated with multivariate analyses and an index of diversity. The analyses indicate that the diatom composition differs in the relative abundances of taxa among seven macroscopically identified patch types in a short reach of sycamore Creek, Arizona. These differences are partly associated with the type of substrate and partly with the development of Iarge masses of diatoms, principally Nitzschia fonticola, on the Cladophora and sand substrates. The diversity index indicates this dominance of N. fonticola in some patch types and the between-habitat component of diversity is due to the patchiness of diatom distribution.

Busch/Arizona/ freshwater/ stream/diatom/diversity/ species Iistl

Busch, D.E. and Eisher, S.G. 1981. Metabolism of a desert stream. Ereshwater Biol. 11:301-307.

Rates of photosynthesis and community respiration were determined for benthic assemblages in sycamore Creek, a sonoran Desert stream in Arizona. Benthos in this stream can be separated into ( 1 ) mats of Cladophora glomerata and associated epiphytes and ( 2 ) assemblages of epipelic diatoms and blue-green algae. Community respiration and net photosynthesis were measured for these assemblages using submerged light-dark chambers in situ. Multiple regression analysis was used to predict (1) gross photosynthesis as a function of photosynthetically active radiation, temperature and chlorophyll-a concentration; and ( 2 ) community respiration as a function of 
temperature and biomass. Calculations suggest that sycamore Creek is autrophic during the summer ( gross photosynthesis $\left(P=8.5 . g O_{2} m^{-2} d_{a y}^{-1}\right)$ and community respiration ( $R=5.1 \mathrm{~g} \mathrm{O}_{2} \mathrm{~m}^{-2}$ day-1) are high for a smali stream. Considerable difference exists between the cladophora mat assemblages, in which mean $\mathrm{p}$ is $12.5 \mathrm{~g} \mathrm{O}_{2} \mathrm{~m}^{-2}$ day-1 and the $\mathrm{p} / \mathrm{R}$ ratio is 2.3, and epipelic assemblages in which mean $P$ is 4.4902 $m^{-2} d a y^{-1}$ and $p / R$ is 0.96 . The high rate of gross

photosynthesis, low litter inputs, high biomass of algae and the interinitent but severefloods that characterize sycamore Creek indicate that this stream and other similar desert streams are ret exporters of organic matter and are, thereby, truly autotrophic stream ecosystems.

Busch/ Arizonal freshwater/ stream/ blue-green algael diatom/ green algael ecology/ production/ cultures'

Button, K.S. and BIinn, D.W. 1973. Preliminary seasonal studies on algae from upper Lake Mary, Arizona. J. Arizonz Acad. Sci. $8: 80-83$.

This describes a high elevation lake in northern Ariana. Over $100 \mathrm{taxa} a r e$ I isted. Aphanizomenon blooms in the summer; diatoms bloom in the spring; Pandorina bloom in winter. The lake is slightiy eutrophic or mesotrophic.

Button/ Arizona/ freshwater/ lake/ Chrysophyta/diatom/ blue-green algae/ Euglenophyta/ dinoflagellatel species list/

Button, K. S. and BIinn, D.W. 1975. Planktonic diatom fluctuations in a northern Arizona mountain lake. Southwestern Nat. 20:397-408.

Upper Lake Mary is a long, shallow, eutrophic lake. Nutrient levels are relatively high during most of the year, particularly nitrate-nitrogen and total silica. The shallow nature of the lake and long fetch al low prevailing winds to continualiy redistribute nutrients throughout the water column. Sixteer physico-chemical parameters were measured at regular intervals throughout the year and correlated with the seasonal dynamics of 18 diatom species. Seasonal silica averaged 5.2 mg/i and showed an inverse correlation to seasonal diatom populations. Total diatom populations maintained a complex successional sequence with Melosira granulata var. angustissima the dominant species in the lake.

Button/ Arizona/ freshwater/ lake/ diatom/ chemistryl nutrients/ succession! 
Cameron, R.E. 1969. Abundance of microflora in soils of desert regions. Tech. Rept. 32-1378, Jet Propul. Lab., Pasadena, California. $16 \mathrm{p}$.

Surface soils were collected by aseptic techniques from cold, polar, hot volcanic, and high mountain deserts, and were analyzed for physical, chemical, and microbiological properties. Soils showed a wide range of properties but were generally greyish, yellowish, or brownish sands, low in organic matter and cation exchange capacity. There were detectable concentrations of water-soluble ions, and $\mathrm{pH}$ values above 7 . 0, except in volcanic areas. Total microbial abundances ranged from zero (urdetectable) to $>10^{9} \mathrm{gm}^{-1}$ of soil. Aerobic and microaerophilic bacteria were most abundant, followed by algae and molds. The anaerobic bacteria were generally least abundant or undetectable. Predominant microflora included Bacilius spp., soil diptheroids, Schizothrix spp. and other osciliatrioid blue-green algae, Streptomyces spp., Penicilitum 5pp., and Aspergilius spp.

Cameron/ Californial Oregon/ Arizona/ New Mexicol soill Blue-green algael green algael

Cameron, R.E. 1964 . Terrestrial a lgae of southern Arizona. Trans. Am. Microsc. Soc. 83:212-218.

Terrestrial algae are represented by blue-green algae, green algae, yellow-green algae, euglenoids, and diatoms of at least 14 families containing 59 species, many of which are frequently parasitized by tungi. Blue-green algae are the most prominent in abundance and number of species. The oscillatoroid forms reproduce more rapidly than other forms, although slower-growing algae become established as climax members of desert algal communities. Distribution and abundance of species is determined primarily by available moisture and light and secondarily by the hydrogen-ion concentration.

Cameron! Arizonal soil/ blue-green algael green algael Chrysophyta/ diatom/ Euglenophytal species list/ illustrations/

Cameron, R.E. 1960. Communities of soil algae occurring in the Sonoran Desert in Arizona. J. Ariz. Acad. Sci. 1: 85-88.

One hundred and sixty-five soil samples were moistened and incubated. From these, 72 species of algae were identified. Mostly blue-greens, but some green algae as well as other forms. Generally samples were algal or lichen crusts.

Cameron' Arizonal soill blue-green algael green a species i istl 
Cameron, R.E. 1962 . Species of Nostoc Vaucher occuring in the Sonoran Desert of Arizona. Trans. Am. Microsc. Soc. B1: $379-384$.

Seven species of Nostoc vauch. Were found in the area of the Sonoran Desert in Arizona. These included Nostoc commune Vauch., N. IIipsospporum rabenh., N. microscopicum carm., N. muscorum Ag. N. parmeliodes Kuetz, $N$, pruniforme (L.) Ag., and $N$. verrucosum (L.) Vauch. The species were found in aquatic or terrestriai habitats as influenced by environmental factors of available moisture, dicect sunlight, and soil conditions, especially moisture retention. Nostoc muscorum was predominant anong the species collected and frequently found to be parasitized or lichenized on dry soil. Plants of some species were found to survive, grow and reproduce after stored in the dried condition for some years.

Cameron/ Arizonal freshwater/ soil/ spring/pool/stream/ blue-green algael environmental factorsl

Cameron, R.E. 1963. AIgae of southern Arizona. Part 1. Introduction - blue-green algae. Rev. Algologique (N.S.) 6: $282-318$.

Of one thousand two hundred algal specimens collected in southern Arizona, it was found that most of the species were blue-green algae. These were collected primarily from the soil and in the Sonoran Desert. Representatives of seven families, thirty-two genia and eighty-six species were found. The commonest species included Microcoleus vaginatus (Vauch.) Gom.) M. chthonoplastes (Mert.) zanard., Scytonema homanni Ag., Schixothrix macbridei Dr., Nostoc muscorum Ag., and Plectonema nostocorum Born. These algae commonly occurred in soil algal communities and were frequently parasitized. The oscillatorioid forms were most abundant.

Cameronl Arizonal soil/spring/ streaml lake/pool/ blue-green algae/ species list/

Cameron, R.E. 1964. Algae of southern Arizona. Part II. Algal flora (exclusive of blue-green algae). Rev. Algologique (N.S.) 7: 151-177.

Among one thousand two hundred random specimens of algae collected in Arizona wre found fifty-four species of green algae and twelve other species of nongreen algae (exclusive of blue-green algae). At least sig species were found to occur in a lgal soil crusts. Others were found in aquatic and semi-aquatic habitats. The commonest algae occurring in soil crusts included protococcus greviliei Ag. Crouan and stichococeus subtilis 
Kuetz. KIerck. These were in many cases found in association with bIue-green algae in a parasitized or lichenized condition. The algal flora of southern Arizona and its desert confines has been found comparable with that found elsewhere in southwestern United 5 tates and northwestern Mexico.

Cameronl Arizonal treshwater/ springl stream/ pooll soill green algael Chrysophytal diatom/ Euglenophytal dinoflagellatel species i istl

Cameron, R.E. and BIank, G.B. 1966. Desert algae: Soil crusts and diaphanous substrata as algal habitats. Jet Fropul. Lab. Tech. Rept. No.32-971, p1-41.

The most favorable habitats in desert soils occur in algal and lichen soil crusts, and on the undersurface of translucent or transparent material partially imbedded in the soil surface. Algal abundance is increased and ecological factors are much less restrictive in these ecological niches than in the sur rounding desert soil. Insolation is modified, more moisture is retained, dessication is reduced, and organic matter accumulations are noticeable. Characteristics of translucent materials, such as white or milky quartzand chalcedony, which are partially imbedded in the surface of desert soils, permit the existence of mesophilic algal inhabitants, such as species of coccoid and blue-green algae, that do not normaliy occur as components of xeric soil populations. Other species are cosmopolitan forms occurring in a wide range of environments, including habitats at low or high elevations in hot or cold deserts. The probable occurrence of a number of translucent and transparent minerals in extraterrestrial soils and other geological materials may also provide a favorable ecological niche or microenvironment for organisms and associated organic matter in an otherwise harsh macroenvironment.

Cameron/ Arizona/ California/ Nevada/freshwater/ saline/ soill diaphanous substrata/ blue-green algael green algael review/ i l lustrations/

Cameron, R.E. and Fuller, W.H. 1960. Nitrogen fixation by some algae in Arizona soils. Soil Sci. Soc. Am. Proc. 24: $353-356$.

Algal and lichen crusts and subsurface soil samples were collected from virgin and cultivated areas and analyzed for nitrogen and carbon. These crusts were incubated in the laboratory to determine if nitrogen could be fixed with time under the conditions stated. Algae isolated from the crusts also were tested for nitrogen-fixing ability and quantitative information was obtained for some species in pure and mixed culture experiments. Species of algae belonging to the genera 
Nostoc Vauch., Scytonema Ag., and Arabaena were shown to fix atmospheric nitrogen. Certain coccoid forms may fix nitrogen. In the absence of Aztobacter, soil a Igae were shown to grow autotrophicaliy and to contribute appreciably to the combined carbon and nitrogen status of Arizona soils.

Cameron/ Arizona/ freshwater/ soil/ blue-green algae/ lichens/ nitrogen fixationl culturesl

CarIson, J.S., Everett, L.G. and Qashu, H.K. 1971. Chemical and biological patterns in the lower colorado River system. Unpub. Rept., Univ. of Arizona. Unpaged.

Results presented in this paper are intended: 1) to stimulate interests for discussions of abiotic-biotic interactions in the Colorado River System, 2) to identify some hydro-biological patterns to guide our current research program, and 3 ) to identity appropriate analytic procedures and sampling. Spatial and temporal variabilities in system properties are real and considered in the current research program on Lake Mead. These changes are caused by the nature of changes in inputs--water, sediments, solutes, sewage effluent, and other recreational products. Degradation of the phytoplankton and zoolankton were observed and changes in species dominance was illustrated across Lake Mead and in other parts of the Lower Colorado River system. causes of these changes are speculative at this time and may be associated with changes in concentrations of essential nutrient species. Limiting arounts of some essential micro-nutrients were documented in areas showing undesicable changes in plankton species. The increase in many ions may in fact cause the absence of chariges in the biota or serve to enhance the limiting effects of low concentrations of micronutrients.

Carlson/ Utah/ Arizona/ Nevada/ Californial freshwaterl blue-green algael diatom/ green algaeldinoflagellatel zoologyl chemistryl

Chantanachat, S. and Bold, H.C. 1963. Phycological studies II. some algae from arid soils. University of Texas, Austin. $75 \mathrm{p}$.

Species from soil samples were cultured. Crowth on various media is discussed. This paper also describes some new species and their cytology and taxonomy.

Chantanachat/Arizona/Utah/freshwater/ soil/grean algae/ biue-green algael diatom/ species list/ cultures/ taxonomyl il Iustrationsl

Cole, G.A. 1963. The American Southwest and Middle America. In 
Erey, D.G., (ed). Limnology in North American, Chpt.14, p. 393-434. Univ. of Wisc. Press, Madison, Wisconsin.

This is a good general review of al 1 aquatic habitats in the American Southwest and Middle America (Mexico and Central America). Descriptions by area and habitat are provided. The author includes some comparative chemical data. There are various algae mentioned in the text.

Colel Californial Nevada/ Arizonal Utah/ New Mexicol Coloradol Texas/ saline/freshwater/ lake/ stream/ spring/ pond/ blue-green algae/ green algae/diatom/ chemistry/general/ reviewl

Cole, G.A. and Whiteside, M.C. 1965. Kiatuthlanna - A limnological appraisal. II. Chemical factors and biota. PIateau $38: 36-48$.

The author mentions the occurrence of Oscillatoria and diatoms. Chemical analyses of the ponds is also given. The two salt ponds at Kiatuthlanna exhibit $11 \%$ and $22 \%$ salinity when isothermal and concentrated in mid-August. Red Pond is more saline and represents the chloro-carbonate category. Green Pond contains relatively more carbonate. Biota include: Scirpus validus and Ctenocladus at Green Pond; $S$. olneyi and S americanusat Red; Artemia, Ephydra and Culicoides in both.

Cole/ Arizona/ saline/ pond/blue-green algae/ diatom/ green algael chemistryl

Cole, G.A. and Whiteside, M.C. 1965. An ecological reconnaisance of Quitobaquito Spring, Arizona. J. Ariz. Acad. Sci. 3: $159-163$.

This paper discusses the chemistry of several springs and a pond. Algal species arementioned in the text. Measurements of productivity by light and dark bottle oxygen technique are given.

Cole/ Arizona/ freshwater/ spring/ pond/ chemistry/diatom/ green algae/ blue-green algae/ production/ zoology/

Cole, G.A., Whiteside, M.C. and Brown, R.J. 1967. Unusual monomixis in two saline Arizona ponds. Limol. Oceanogr. 12: $584-591$.

Red Pond and Green Pond are shallow, saline pools in Apache County, Arizona, that stratify chemically during winter and circlate in midsummer. Stability is brought about by addition of 
dilute runoti and seep water to the surfaces; circulation occurs because evaporation increases the salinity of the upper waters and lowers the pond surfaces. Isothermy, dichothemy, mesothermy, and poikilothermy occur during the year. Winter stabilities are in excess of $200 \mathrm{~g}-\mathrm{cm} \mathrm{cm}^{-2}$ in spite of anomalous temperature profiles an the shallow nature of the ponds. The waters are chlorocarbonates derived by concentration from dilute waters relatively high in sulfate and carbonate. At the overturn, Red Pond and Green Pond have 5 alinities of $22 \%$ and $11 \%$. Phosphate concentrations are remarkably high--up to $500 \mathrm{mg}$ i iter in Red Pond. Ctenocladus circinnatus is present in both ponds; this may be the fourth North American record for this green algae.

Cole/ Arizona/ saline/ pond/ green algae/ chemistry/

Crane, N.L. and Sommerfeld, M.R. 1977. Phytoplankton ecology of Lynx Lake, Arizona. Southwest. Nat. 22:305-320.

Species composition and population size of the phytoplankton of Lynx Lake, Az, were investigated from February to september, 1974. Only 23 species of phytoplankton were recorded. The mean phytoplankton standing crop was found to be low (1230 organisms mil), with a single peak occuring in July. The mean extractable chlorophyl a value was $2.95 \mathrm{mg} \mathrm{m}^{-3}$. During the winter, the lake was isothermal; thermal stratification developed in May. Surface water temperatures ranged from 4.5 C in February to 22 C in July. Summer dissolved oxygen concentrations were less than $10 \mathrm{mg} \mathrm{I}^{-1} \mathrm{bel}$ low the thermoci ine, a lthough surface waters remained we 11 -oxygenated. The lake is a calcium bicarbonate water with stable concentrations of major cations and anions. The trace elements cadmium, chromium, cobalt, copper, lead and molybdenum were all found to be below $20 \mu g 1$ during the study period. Iron, manganese, and zinc, were a 1 so present in low concentrations, but showed considerable fluctuation. Levels of the nutrients nitrogen and phosphorus were consistently low except during the late summer months. This study suggests that the low standing crop and Iimited diversity of the phytoplankton of Lynx lake is a result of the low nitrogen and phosphorus concentrations and is not due to the toxicity of certain heary metals.

Crane/ Arizona/ freshwater/ green algael diatom/ Chrysophytal Euglenophyta/ dinoflageliate/ chemistry/ nutrients/ trace metals/ successionl

Crayton, W.M. and Sommerfeld, M.R. 1979. Composition and abundance of phytoplankton of the lower Colorado River, Grand Canyon Region. Hydrobiologia 66: 81-93.

Phytoplankton distribution and abundance in eleven tributaries of the Colorado River within the Grand Canyon were investigated 
from April 1975 to June 1976. During this period a total of 56 genera and 156 species of phytoplankton was identified. Phytoplankton species of the individual tributaries were quite distinct, with only four diatom species, Diatoma vulgare, Navicula tripunctata, Nitzschia linearis and Synedra ulna, common to ali tributaries. Bright Angel Creek, Shinumo Creek, and Elves Chasm were the tributaries with the most diverse algal flora, whereas Vaseys Paradise, Tapeats Creek, Deer Creek and Havasu Creek showed the lowest species richness. Elves Chasm and Diamond Creek had the highest phytoplankton numbers. Phytoplankton abundance and species richness appeared to be influenced by high turbidity, current velocity, fluctuating water levels and age of the water. Some of the dominant algal species, Biddulphia Iaevis, Cocconeis pediculus, Cymbella ventricosa, Epithemia sorex, Gomphonema parvulum and synedra ulna, showed significant corcelations with specific physico-chemical characteristics of the tributaries.

Crayton/Arizonal freshwater/ river/ streamldiatom/ blue-green algael Green Algael species Iist/

Crayton, W.M. and SommerfeId, M.R. 1977. Distribution and abundance of phytoplankton in the Colorado River from Lee's Ferry to Diamond Creek. J. Ariz. Acad. Sci. 12(suppl): 20.

Phytoplankton distribution and abundance in the Colorado River was investigated from April 1975 to June 1976 . During this period a total of 64 genera and 131 species of phytoplankton were identified in the River. Of the 131 species, 77 were diatoms, 27 were green algae, 22 wereblue-green algae, 2 were dinoflageliates, 2 were euglenoids, and 1 was a cryptophyte. Diatoma vulgare, Cocconeis pediculus and Rhoicophenia curvata were the dominant algal species in the Colorado River. Phytoplankton numbers were low throughout the sampling period (Iess than 5,000 literl). Phytoplanktor abundance and diversity appeared to be influenced by turbidity, turbulence, low temperature, rapid current, fluctuating river levels, and age of the water. A number of algal species occurring in the Colorado River showed significant correlations with specific physico-chemical parameters.

Crayton/ Arizonal freshwater/ riverl diatom/ green algael bIue-green algae/ dinoflagellatel Euglenophyta/ Cryptophytal diversityl

Crayton, W.M. and SommerfeId, M.R. 1978. Phytoplankton of the lower Colorado River, Grand Canyon region. J. Ariz. - Nev. Acad. Sci. $13: 19-24$.

The Colorado River is characterized by a small evenly distributed phytoplankton population which is dominated by 
tychoplankters. Of the 127 species found suspended in the river, 73 were diatoms. The dominant species were Diatoma vulgare Bory, Rhoicosphenia curvata (Kutz.) Grun. and Cocconeis pediculus Ehr. OnIy a few euplanktonic species in low numbers were found in the river and they were common to the upstream reservoir, Lake Powel1. Although the Colorado River appeared to be chemically satisfactory for development of a euplanktonic population, the low temperature, high turbidity and limited age of the water appear to preclude its development. The presence of primarily tychoplanktonic forms in the colorado River probably results from the widely fluctuating river levels, high current velocity and $t$ urbuI $\cos c$.

Crayton/Arizona/freshwater/ river/Chrysophyta/ Xanthophyta/ diatom/ green algae/ blue-green algae/ Cryptophytal dinoflageliate/ Euglenophyta/ species Iist/

Czarnecki, D.B. and BIinn, D.W. 1977. Diatoms of lower Lake Powell and vicinity. Biblio. Phycol. 28: 1-119.

Describes diatoms from Lake Powell with species lists, keys, and i l l ustrations.

Caarneckil Arizona/ Utah/ freshwater/lakeldiatom/ taxonomyl species list/ illustrations/

Czarnecki, D.B. and BIinn, D.W. 1978. Observations on southwestern diatoms. I. Plagiotropis arizonican. sp. (Bacillariophyta, Entomoneidaceae), a Iarge mesohalobous diatom. Trans. Am. Microsc. Soc. 97: 393-396.

A new diatom species, Plagiotropis arizonican. sp., is described on the basis of characteristics visible with the light microscope. The occurrence of this organism in inland waters is particularly interesting, since most members of the genus are considered marime or brackish water forms. The type-locality of this taxon indicates a preference for water of high conductivity and chloride content.

Czarnecki/ Arizona/ saline/lake/ stream/diatom/ illustrations/ taxonomyl

Czarnecki, D.B. and Blinn, D.W. 1979 . Observations on southwestern diatoms. II. Caloneis latinscula var. reimeri n.var., Cyclotelia pseudostelígera f. parva n. . and Gomphonema Montezumense n.sp., new taxa from Montezuma Well National Monument. Trans. Am. Microsc. Soc. 98: 110-114.

Morphological features are presented which describe three new diatom taxa, Caloneis latiuscula var. reimeri, Cyclotella 
pseudostelligera f. parva, and Gomphonema montezumense from Monteruma WelI National Monument, a unique solution-collapse basin in north-central Arizona. Their occurrence, thus far, appears to be restricted to this environment.

Caarnecki/ Arizona/ saline/ spring/ diatom/ taxonomy/ il I ustrations'

Czarnecki, D.B. and BIinn, D.W. 1978. Diatoms of the Colorado River in Grand Canyon National Bark and vicinity.

Bibliotheca Fhycologia $38: 1-181$.

Two hundred and thirty-five diatom taxa were encountered. These are Iisted with the specific location where they were found. The taxa are illustrated and identification keys are provided.

Caarnecki/ Arizona/freshwater/ river/ stream/ spring/diatom/ illustrations! taxonomyl

Everett, L.G. 1972. A mathematical model of primary productivity and $l$ imnological patterns in Lake Mead. Repts. Nat.

Resource Systems No.13. $151 \mathrm{p}$.

Dominant algae were Asterionella and Ceratium. The temporal and spatial changes in chemical and biological properties of Lake Mead have been investigated, thereby indicating the sources of water pollution and the time of highest pollution potential. PIanktonic organisms have been shown to indicate the presence of water problems. Macro- and micro-nutrient analyses have shown that primary productivity is not inhibited by limiting concentrations. A mathematical model has been developed, tested with one set of independent data, and shown worthy of management utility. Although the model works very well for the Lake Mead area, the physical reality of the Multiple Linear Regression equation should be tested on independent data.

Everett/ Arizona/ Nevada/ freshwater/ Iake/ diatom/ dinoflagellatel production' ecology' chemistry/ zoology/ nutrientsl

Everett, L.G., Carlson, J.S. and Qashu, H.K. 1971. Chemical and biological patterns in the lower Colorado River system. J. Ariz. Acad. Sci. 8: 91-94.

The abundance of diatoms and green algae decreased in a downstream directon from Lake Fowell to Lake Mead to Lake Havasu. These algae were replaced by filamentous blue-green a lgat and dinoflagellates. There is only speculation as to why these changes occur - possibly because of water chemistry 
changes or changes in grazing pressure.

Everett/ Arizona/ Nevada/ California/ Utahl freshwater/ river/ diatom/ green algael dinoflagellatel blue-green algael zoologyl chemistry/ nutrients/

Farnsworth, R.B. and Martin, T.L. 1948. The presence and some activities of algae in some western soils. Proc. Utah Acad. Sci. Arts and Lett. $26: 148$.

This is an abstract reviewing the importance of soil algae and giving some numbers per gram of soil.

Farnsworth/Utah/ Arizonal freshwater/ soil/ biue-green algael green algael culturesl

Faust, W.E. 1971. Blue-green algal effects on some hydrologic processes at the soil surface. In Hydrology and Water Resources in Arizona and the Southwest, Proc. 1971 Meeting of the Ariz. Section of the AWRA and the Hydrology Section of the Arizona Acad. Sci., Tempe, Arizona. p.99-105.

Algal growths (blue-green species listed in text) prevent surface erosion of fine sediments in test plots.

Faust/ Arizona/ freshwater/ saline/ soil/ blue-greenalgael hydrology

Eisher, S.G., Gray, L.J., Grimm, N.B. and Busch, D.E. 1982 . Temporal succession in a desert stream ecosystem following flash flooding. Ecol. Mono. 52:93-110.

Recovery of a desert stream after an intense flash flooding event is described as a model of temportal succession in lotic ecosystems. A late summer flood in sycamore Creek, Arizona, virtualiy eliminated algae and reduced invertebrate standing crop by $98 \%$. Physical and morphometric conditions typical of the preflood period were restored in 2 d and the biota recovered in 2-3 wk. Algal communities responded rapidly and achieved a standing crop of nearly $100 \mathrm{~g} \mathrm{~m}^{-2}$ in 2 wk. Community composition was dominated by diatoms early in succession and by filamentous greens and blue-greens later. Macroinvertebrates a 150 recolonized denuded substrates rapidiy, Iargely by immigration of aerial adults and subsequent oviposition. Growth and development were rapid. Invertebrate dry biomass reached 7.3 $g \mathrm{~m}^{-2}$ in one mo. Gross primary production measured as orygen increased in a similar asymptotic fashion and reached $6.6 \mathrm{~g} \mathrm{~m}^{-3}$ $d^{-1}$ in 30 d. Gross primary production exceeded communty respiration after day 5 and gross primary productionlrespiration 
averaged 1.46 for the remainder of the 2-mo sequence. This ecosystem is thus autotrophic and exports organic matter downstream and by drying, laterally. Uptake of nitrate and phosphorus were proportional to net primary production and exhibited a marked downstream decline in concentration during both light and dark periods.

Fisher/Arizona/freshwater/ stream/ blue-green algael green algael diatom/ successionl

Eletcher, J.E. and Martin, W.P. 1948. Some effects of algae and molds in the rain-crust of desert soils. Ecology 29: $95-100$.

The algae present were all Cyanophyceae of the genera: Osciliatoria, Nodularia, Microcoleus, Nostoc, and several members of the family Chroococcaceae. Molds identified by hyphal transfers to Czapek's agar were Rhizopus, Mucor, and probably Botrytis. Increases of as high as $300 \%$ in organic carbon content and $400 \%$ in nitrogen content occurred in the crusts where microbial growth had been extensive. The largest increases in $N$ were in the crusts containing the nitrogen-fixing algae, Nostoc. The free-living, aerobic, nitrogen-fixing Azotobacter were not present in any of the soils tested.

Fletcher/ Arizonal freshwater/ soil/blue-green algael green algael nitrogen finationl

Flowers, 5. 1959. Algae collected in Glen Canyon. Appendia D. In Woodbury, A.M., (ed). Ecological studies of the flora and fana in GIen Canyon. Anthropological Bapers, Gien Canyon Ser. No.7, Dept. of Anthropology, Univ. of Utah. p.203-205.

This paper lists species and locations within Glen canyon where they were found.

FIowers/ Utahl Arizonal freshwater' riverl green algael blue-green algael diatom/ species list/

Eulier, W.H., Cameron, R.E. and Raica, Jr., N. 1960. Eixation of nitrogen in desert soils by algae. Trans. Seventh Int.

Congr. Soil Sci., Madison, Wisconsin. p.617-627.

Many genera of algae obtained from desert crusts were identified as belonging to the orders of Cyanophyta, Chlorophyta, Chrysophyta, Pyrophyta, Englenophyta and Diatoms. Over halfof the genera identified were blue-green algae. Many of the blue-green a Igae were shown to be autotrophic both with respect to nitrogen as well as carbon. Algal and lichen crusts were 
found to be four to five times as high in nitrogen as the soil below. Both algal crusts and algae in pure and mixed cultures were found to fix nitrogen. This nitrogen was shown to be available to plants.

Fuller/Arizona/ soil/blue-greenalgae/green algaeldiatoml dinoflageliate/ Chrysophyta/ Euglenophyta/ nitrogen fiation/

Getz, M.R., Sommerfeld, M.R., and Wujek, D.E. 1979. Scaled chrysophyceae of Arizona, a preliminary survey. J. Ariz. Acad. Sci. $14: 75-80$.

This study represents the first attempt to critically identify scaled Chrysophyceae from Arizona lakes and ponds. In all, ten species (five genera) are reported including: Mallomonas acaroides, M. akrokomos, M. annulata, M. papiliosa, M. striata, Synura petersenii, Chrysosphaerelia brevispina, paraphysomonas

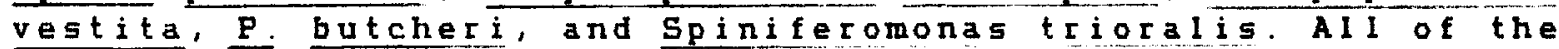
taxa reported are new published records for Arizona. Two species

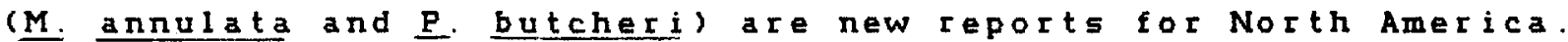

Getz/ Arizona/ freshwater/ Iake/ pond/spring/ Chrysophyta/ i 1 lustrationsl

Heviy, R.H. 1961. Notes on aquatic non-flowering plants of northern Arizona and adjoining regions. Flateau 33:88-92.

This paper describes a few algae collected at various sites in northern Arizona, southern Utah, and southern Nevada.

Hevly/ Arizonal Utahl Nevada/ freshwaterl streaml lakel pond/ green algael blue-green algael

Hoham, R.W. and BIinn, D.W. 1979. Distribution of cryophilic algae in an arid region, the American Southwest. Phycologia $18: 133-145$.

In the American southwest, species distribution was related mostiy to exposure. ChIoromonas nivalis was the dominant species found in thirty-one of thirty-four collecting areas containing snow algae. It caused green to orange colouration of snow in mostly shaded regions of the forests. Cryocystis granulosa cell type was most prevalent in the southwestern portion of the study area. It caused orange to orange-red colouration of snow near tree canopies and usually received more irradiation than populations of Chloromonas nivalis. Carteria nivale - Scotielia polyptera cell types dominatedin each of the six collecting areas where they were found in shaded regions in the eastern portion of the study. These cell types caused green colouration, 
usually in horizontal bands up to 25 cm below the 5 urface in residual snowbanks. Chlamydomonas nivalis prevailed above timberline at the northern region of the study. This species caused red snow and dominated in the open exposures. Chromulina chionophilia and a colourless euglenoid flagellate were found at scattered localities in the southwest. Chromulina was found in open exposures and near tree canopies. The colourless euglenoid was found only in the shaded snowbanks near trees, and this is the first report of a colourless alga from snow. In the American Southwest, orange and green snow were the dominant types.

Hoham/ Arizona/ New MexicolUtah/freshwater/ snowfields/ green algae/ Chrysophyta/ Euglenophyta/ species Iist/ i I I ustations!

Hostetter, H.P. 1968. Planktonic diatoms in three southern Arizona Lakes. J. Ariz. Acad. Sci. 5: 135-139.

Diatom flora of three lakes near Tucson, Arizona were analyzed from net collections. One hundred fifteen taxa are listed.

Hostetter/Arizona/ freshwater/ lake/ diatoml species listl

Inch, D. and Blinn, D.W. 1981. Limnology of Little Park Lake and diatom distribution on the Kaibab Plateau, Arizona.

Journal Ariz. - Nev. Acad. Sci. 16: 14-21.

Physico-chemical and algal dynamics of Little Park Lake were investigated on a weekly basis throughout the ice-free season. This small, shallow lake, which is formed by a limestonesink, is characteristic of the densely vegetated lakes of the Kaibab Plateau. Decomposition of plant materials is primarily resonsible for poor water transparency and low pH and oxygen concentrations. Evaporation, precipitation, and ambient temperature were important influences on ion concentrations and maxi umum depth. Sixty-two species of algae were identified. The major dominants were al members of the chlorophyta, particularly Microspora tumidula and species in the zygnematales and Chlorococales. Stauroneis phoenicenteron was the only important dominant not in the Chlorophyta. Major algal blooms occurred throughout the summer and into the fall, with a maximum of 7.95 8 $10^{4}$ celis $\mathrm{mi}^{-1}$ counted on August 26 . A truly planktonic a Igal flora appears to be lacking in Little Park Lake, and the majority of algal species sampled in the plankton appear to have originated from Iittoral and metaphytic populations.

Inch/ Arizonal freshwater/ lake/ springl diatom/ green algael Chrysophyta/ blue-green algae/ Cryptophyta/ Euglenophyta/ dinoflagellate/ species Iist/ nutrients/ chemistry/ 
Johnson, R., Richards, T. and Blinn, D.W. 1975. Investigations of diatom populations in rhithron and potamon communities in Oak Creek, Arizona. Southwest. Nat. 20:197-204.

A study of diatom populations using artificial glass substrates was made in Oak Creek, Arizona. A total of 41 diatom species were recorded with quantitative and qualitative changes in diatom populations measured between thithron and potamon zones. Notably, there was a distinct change from an epilithic cold water flora (e.g. Meridion circulare) in the rhithron zone to an epiphytic warm water flora (Cocconeis spp, Epithemia spp) in the potamon zone. A decrease in diatom diversity was also noted between the rhithron and the potamon zone. Colonization rates in the rhithron zone were greatest at slower current velocities (e.g. $4.5-35.0 \mathrm{~cm} \mathrm{sec-1)} \mathrm{for} \mathrm{short} \mathrm{incubation} \mathrm{periods} \mathrm{(} 3$ weeks). Nitzschia palea and Gomphonema parulum were very common in various regions of the stream bed suggesting nutrient-rich conditions.

Johnson/ Arizona/ freshwater/stream/ diatom/ chemistry/ species $\mid$ istl

Kidd, D.E. 1965. The taxonomy and ecology of polluted ranch ponds in northern Arizona. Yearb. Am. Fhilos. Soc. 1965. p325-327.

This is a short description of alge in various parts of Arizona, including Quitobaquito in Organ Pipe Cactus National Monument. Not much specific information is presented.

Kidd/ Arizonal freshwater/ pond/ blue-green algael green algael ecology' taxonomy

Kidd, D.E. 1966. Algae taxonomy and ecology in northern Arizona. Yearb. Am. Philos. Soc. 1966, p358-359.

This paper contains a short description of algal studies at one ranch pond near flagstaff, Arizona. Not much specific information is given.

Kidd/ Arizona/ freshwater/ pond/ green algae/ blue-green algae/ ecologyl taxonomyl

Kidd, D.E. and Wade, W.E. 1965. Algae of Quitobaquito: A spring-fed impoundment in Organ Pipe Cactus National Monument. Southwest Nat. 10:227-233.

Algae collected from Quilobaquito in Organ Pipe Cactus National 
Monument in southwestern Arizona are listed along with a description of Cosmarium garrolense var. minor var.nov.

Kidd/Arizona/freshwater/ pond/ green algae/ Chrysophytal blue-green algael dinoflagellatel chemistry/ species listl

Kidd, D.E. and Wade, W.E. 1963. Algae of Montezuma Well, Arizona and vicinity. PIateau 36: 63-70.

This paper records species of algae found in Montezuma Well and in nearby Beaver Creek.

Kidd/ Arizona/ freshwater/ wells/ stream/ green algael Chrysophyta/ Euglenophyta/ bIue-green algael dinoflageliatel species list/ illusteations/

La Rivers, I. 1978. Algae of the Western Great Basin. Bioresources Center, Desert Research Institute, University of Nevada system, Reno, Nevada. $390 \mathrm{p}$.

This book is a reasonably complete description of al algae occurring in Nevada (particularly the western part of the state) and in eastern California; some algae are recorded from Arizona. The book contains keys and illustrations and discusses the history of algal research in these areas. The book has a glossary and index. Locations are given for each species. Chlorophyta, Euglenophyta, Chrysophyta (with diatoms), Cyanophyta, and Rhodophyta are included. This is a definitive work on desert algae.

La Rivers/ Nevada/ CaIifornia/ Arizona/ salinel freshwater/ Iake/ soil/ pond/ stream/ springl blue-green algael green algael Euglenophyta/diatom/ Chrysophyta/ general/ taxonomy/ i I I ustiationsl

Lampkin III, A.J. and Sommerfeld, M.R. 1982. Algal distribution in a small intermittant stream receiving acid minedrainage. J. Phycol. 18: 196-199.

Lynx Creek, a smal1 intermittent creek in the Bradshaw Mountains of Arizona, is subjected to drainage from an abandoned copper mine. The mine-drainage decteases the pH of the Creek about three units and greatly increases sulfate and heavy metal concentrations. Chemical recovery of the creek occurs downstream through precipitation of metal hydroxides and dilution by tributaries. Changes in Creek chemistry are accompanied by changes in algal flora. Above the mine and downstream after substantial recovery, the flora is dominated by Tribonema aftine, Achnanthes spp., and Synedra ulna and several 
zygnematacean species. In the mine seep entering the creek and in the Creek just below the seep the flora is reduced in species and dominated in abundance by Microthamnion kuetzingianum and Eunotia tenella.

Lampkin/ Arizona/freshwater/ stream/ blue-green algae/ green algaeldiatom/ chemistry/ species Iistl

Luty, E.T. and Hoshaw, R.W. 1967. Airborne algae of the Tucson and Santa Catalina mountain areas. J. Ariz. Acad. Sci. 4: $179-182$

Membrane filters through which air had been pumped were placed on a lgal nutrient agar plates or the plates themselves were exposed to the air. Plates incubated at constant temperature and light resulted in colonies of algae on the agar surface. The 104 isolates consisted of 16 genera. Most were soil algae. It was not possible to correlate abundance of species with weather or other environmental factors.

Luty/Arizona/ soilf aic/green algael blue-greenalgaeldiatoml species list/cultures!

MacGregor, A.N. and Johnson, D.E. 1977. Capacity of desert algal crusts to fix atmospheric nitrogen. Soil Sci. Soc. Am. Proc. 35: 843-844.

Approximately $4 \%$ of the soil surface of an area of desert grassland in the Sonoran Desert of southern Arizona possessed a lgal-crust formations. Samples of dry intact algal crusts were examined for nitrogen fixation by the acetylene-ethylene method. Three hours after being moistened, algal crusts produced detectable levels of ethylene. Premoistened algal crusts were capable of producing ethylene equivalent to 0.7 microgram of $N \mathrm{~cm}^{-2}$ of algal crust per hour. On the basis of these findings, 1 ha of desert grassiand may receive a nitrogen input of 3 to 4 $g$ of $N$ hour $\left(0.3 \mathrm{mg}\right.$ to $0.4 \mathrm{mg} N \mathrm{~m}^{-2}$ per hour) following a ra inf a 11 .

Macgregor/Arizona/ soil/blue-green algae/ nitrogen fixationl

Markey, D.R. 1972. Red snow in Arizona. Southwest. Nat.17:312.

Red snow was found in the San Erancisco Mountains.

Markey/ Arizona/ freshwater' snowfields/ green algael 
Markey, D.R. and Hevly, R.H. 1973. The algae of Lockett Meadow. J. Ariz. Acad. Sci. 8: 119-123.

This paper 1 ists species of algae found in ponds and soils at Lockett Meadow in San Erancisco Mts. near Flagstaff, Az. Taxa include blue-green algae, green algae, Euglenophyta, and diatoms. There is no discussion of why species might occur here.

Markey/Arizona/freshwater/ pond/lake/ soil/diatom/ blue-green algae/green algae/ Euglenophyta/ species Iist/

Mayland, H.F., MeIntosh, T.H., and Fuller,W.H. 1966. Fixation of isotopic nitrogen on a semiarid soil by algal crust organisms. Soil Sei. Soc. Am. Proc. 30:56-60.

Semiarid desert algal crust organisms were found to fix $N$ when exposed to an atmosphere which contained isotopically enriched N. Significant quantities of the $N$ isotope were detected in the total crust $N$ after 3 days of incubation under field-simulated conditions. Net $N$ fixation rates by the algal crust organisms were 0.16 and 0.10 lb of $N$ acre-1 of crust surface per day under continuous wet and cycling wet-dry conditions, respectively. The rate of $N$ tixation under field-simulated conditions increased I inearly for at least 520 days. The amount of $N$ in the algal crust was doubled during this time. No net $N$ change was observed in dry crusts. Growing algal crusts contained $1 \%$ to $2 \%$ of the total $N$ as extraceliular ammonia. Excretion of some fixed nitrogen was suggested by the isotopic encichment of the extraceliular $N$ fraction and uptake of labeled $N$ by grass seedings (Artemesia sp.) growing on incubated crusts.

Mayland/Arizona/soil/ blue-green algae/ nitrogen fixation/

OIsen, R.D. and sommerfeld, M.R. 1970. A preliminary study of planktonic diatoms of central Arizona. J. Ariz. Acad. Sci. 6: $135-138$.

This paper lists species of diatoms occurring in the spring. Differences in chloride content of lakes are noted and the authors speculate that these may affect species distribution differences, but even the latter are not clarified. This is a very preliminary paper.

OIsen/ Arizonal freshwater/ lakel diatom/ chemistryl species $\mid$ ist $/$

Rickert, E.B. and Hoshaw, R.W. 1968. The application of algal culture methods to studies on the distribution of Spirogyra in southern and eastern Arizona. J. Ariz. Acad. Sci.5: 


$$
63-76
$$

The authors describe where various species of spirogyra were tound in Arizona. Species are illustrated with photomicrographs and morphological and cytological differences among species are discussed. There are only speculations as to why species occur where they do. Algal cultures permit better identification than from natural material because spores and reproductive structures can be seen as well as vegetative tilaments.

Rickert/ Arizona/ficeshater/ pool/ lake/ pond/ green algae/ illustrations/ taxonomy/ culturesl

Rickert, F.B. and Hoshaw, R.W. 1970. New records of Spirogyra from southern Arizona. J. Ariz. Acad. Sci. 6: 66-70.

New records of Spirogyra are described; three are new species.

Rickert/ Arizona/ freshwater/ pond/ lake/ green algae/ il Iustrationsl taxonomyl

Schmitz, E.M. 1978. Classified Bibliography on Native Plants of Arizona. University of Arizona Press, Tucson. $160 \mathrm{p}$.

This review mostly covers higher plants, but also a listing of papers on lichens, fungi, and algae is given. Other useful sections include aquatic and riparian vegetation, floras, and general ecology.

Schmitz/Arizona/ ecology/ bibliography/general/ review/

Sommerteld, M.R., Cismeros, R.M. and Olsen, R.D. 1975. The phytoplankton of Canyon Lake, Arizona. Southwest. Nat. 20: $45-53$.

The phytoplankton of a central Arizona reservoir, Canyon Lake, were enumerated from March, 1971 through February, 1972. Over 100 species were identified as belonging to the following classes: Chlorophyceae 42 species, Bacillariophyceae 46 species, Cyanophyceae 8 species, Euglenophyceae 4 species, and Dinophyceae 2 species. More than 50 species are new additions to the algal flora of Arizona. The largest phytoplankton populations were recorded in February-March and August-september.

Sommerfeld/ Arizona/ freshwater' lake/ green algae/ blue-green algael diatom/ Chrysophyta/ Euglenophyta/ dinoflagellatel ecologyl species list/ 
Sommerfeld, M.R., Crayton, W.M. and Crane, N.L. 1976. Survey of bacteria, phytoplankton, and trace chemistry of the lower Colorado River and tributaries in the Grand Canyon National Park. Grand Canyon National Park, Colorado River Research Series Contr. No.40.136p.

This baseline research program has established aquatic monitoring sites on the colorado River and its major tributaries in the Grand Canyon National Park and vicinity that can be used tor future reference. The phytoplankton population in the Colorado River was diverse, but sparse and decreased with distance downstream from Lee's Ferry. Numbers were never found to exceed 3,0001 iter $^{-1}$. A total of 122 species were identified with the common organisms being Asterionella formosa, Sunedra ulna, Diatoma vulgare, Eragilaria crotonensis, and Rhoicoshenia curvata. Phytoplankton were also sparse in the tributaries and never exceeded 12,000 oraganisms mil A total of 137 spies were identified in the tributaries with 71 being confined to Pediculus, Diatoma vulgare and symedra ulna. On the basis of phytoplankton numbers the colorado River and its tributaries must be considered relatively unproductive. (species are listed along with the locations where they were found). The concentrations of 15 chemical elements, including several heavy metals were monitored. Boron, iron and zinc showed large temporal and spatial variations in the colorado River and sodium levels increased 7-13\% with distance downstream from Lee's Ferry. The tributaries differed chemically and showed large variations in boron, calcium, iron, magnesium, and manganese relative to flow. The Little colorado River exceeded water quality standards for iron and manganese during flooding. Otherwise, the dissolved chemical quality of the River and tributaries was generally acceptable based on current water quality standards.

Sommerfeld/ Arizonal freshwater/ river/ streaml green algael bI ue-green algae/ diatom/ dinoflageliate/ Chrysophytal Cryptophyta/ Euglenophyta/ species Iist/ chemistry/

Staker, R.D., Hoshaw, R.W., and Everett, L.C. 1974. Phytoplankton distribution and water quality indices for Lake Mead (Colorado River). J. Phycol. 10:323-331.

Phytoplankton samples were collected in Lake Mead 6 times from September 1970 to June 1971 for 85 tations at depths of $0,3,5$, 10,20 , and $30 \mathrm{~m}$. These samples were processed through a Milipore filter apparatus and 79 planktonic algae were identified. Algal divisions represented were Bacillariophyta, 42 spp.; Chlorophyta, 18 ; Cyanophyta, 9; Chrysophyta, 3; Cryptophyta, $3 ;$ Pyrrophyta, 2; and Euglenophyta, 2. BIue-green algae were dominant in late summer and fall; greenalgae, diatoms, and crytomonads in winter; and green algae in spring. 
The early summer flora was best represented by the chlorophyta, Cryptophyta, and Chrysophyta. Palmer's poliution-tolerant algae indices and Nygard's indices were calculated from phytoplankton data. These indices suggest eutrophic conditions in Lake Mead, especially for Boulder Basin.

Staker/ Arizona/ Nevada/ freshwater/ lake/ blue-green algael green algae/diatom/ Chrysophyta/Cryptophyta/ Euglenophyta/ dinoflagel late/ maps/

Stewart, A.J. and BIinn, D.W. 1976. Studies on Lake PoweIl, U.S.A.: Enviconmental factors influencing phytoplankton success in a high desert warm monomictic lake. Arch. Hydrobiol. $78: 139-164$.

Limological studies were conducted on lower Lake poweli, a large desert reservoir in southwesten USA. Warm Creek Bay was found to be a warm monomictic system that initiated overturn in mid-October to early November. Restratification started about the end of April. Summer thermal stratification led to a zone of oxygen depletion below 15 meters at the two deepest stations. The pattern of seasonal algal succession was typical of that found in many moderate-sized temperate lakes - a spring diatom pulse (Eragilaria crotonensis and Asterionella formosa), a diverse phytoplankton summer community (Dinobryon sertularia and Chloroccocalean), a late autumn diatom (Synedra delicatissima var. angustissima) increase and a pronounced winter phytoplanktor paucity. Corcelation coefficients implicated water temperature as an extremely important regulator of phytoplankton density in Warm Creek Bay. Concentrations of nitrogen compounds often correlated significantly with both total number of phytoplankton cells and individual species.

Stewart/Utah/Arizona/ freshwater/ Iakel diatom/ green algael dinoflageliate/ Euglenophyta/ physics/chemistry/ species list/ successionl

Stewart, A.J. and BIinn, D.W. 1974. Phytoplankton population dynamics in Warm Creek Bay, Lake Powell. J. Phycol. 10(supp 1): 11 .

Seasonal and depth distributions of phytoplankton and selected physio-chemical parameters were followed for a 13 month period in the relatively new Lake Powell reservoir. Three sampling stations, averaging 5,20 , and 40 meters in depth were established a long a transect in Warm Creek Bay. A spring diatom maximum (Fragilaria crotonensis, Asterionelia formosa) was succeeded almost immediately by a long pulse of Dinobryon sertularia. Three species of Scenedesmus showed temporal and spatial niche differentiation. Overturn conditions in october terminated the development of populations of some warm-water 
species (Peridinium willei, Ceratium hirundinelia), while Synedra sp. flourished during the winter months. A strong correlation was found between the mean depth of each station and the abundance of some species - E. crotonensis favored the deepest station while the dinoflageliates and a species of Euglena preferred the shallowest station. Nitrate and phosphate levels were highest after spring rains. The formation of a pronounced thermocline allowed the development of a zone of oxygen depletion ( $22.0 \mathrm{mg} \mathrm{F}^{-1}$ ) during the summer months, and pH values were generaliy lower during the winter months.

Stewart/ Utah/ Arizona/ freshwater/ lake/ diatom/ Euglenophytal green a I ael dinofiageliatel successionl

Taylor, W.D., Willi ams, L.R., Hern, S.C., Lambou, V.W., Morris, F.A., and Morris, M.K. 1979. Distribution of phytoplankton in Arizona Lakes. U.S. Environmental Protection Agency, Ecol. Res. Ser. Rept. No. EPA-600/3-79-112.v+36p.

This is a data report presenting the species and abundance of phytoplankton in the 11 lakes sampled by the National

Eutrophication Survey in the state of Arizona. Results from the calculation of several water quality indices are also included (Nygard's Trophic State Index, Palmer's Organic Pollution Index, and species diversity and abundance indices). Of special interest are lakes along the Colorado River.

Taylor/ Arizonal freshwaterl lakel blue-green algael green algael diatom/ dinoflageliatel Euglenophyta/ Chrysophytal Cryptophyta/ species Iist/ diversityl

Taylor, W.R. and CoIten, H.S. 1928. The phytoplankton of some Arizona pools and lakes. Am. J. Bot. 15: 596-611.

Many of the species are listed from higher elevations $(>3000$ ft.) of state. These probably are not true desert algae and not from saline waters.

Taylor/ Arizonal freshwater/ lake/ pool/ green algael blue-green algael flageliates/ illustrations/

Wade, W.E. and Kidd, D.E. 1963. Algae of West Fork Canyon, Oak Creek, Arizona. Plateau 36:83-88.

Algae found in this habitat are described.

Wade/ Arizona/ freshwater/ stream/ green algael blue-green algael illustrationsl 
Wien, J.D. 1958. The study of the algae of irrigation waters. Ann. Prog. Rept., Arizona State College, Tempe, Arizona. Unpaged.

This report lists species occuring in irrigation canals near Tempe, Arizona. Some chemical data and bioasay data on chemical compounds for controlling algae are given.

Wien/ Arizonal freshwater/ stream/ blue-green algael green algael chemistry/ cultures! species list/

Wien, J.D. 1959. The study of the algae of irrigation waters. Einal Prog. Rept., Arizona state College, Tempe, Arizona. $11 \mathrm{p}$.

This is a continuation of previous (1958) report by wien, but there are less data and speculation about the ecology of algae.

Wien/ Arizonal freshwater / stream/ chemistry/ cultures/

Woodbury, A.M. 1959. Ecological studies of the flora and fauna in Glen Canyon. Anthropological Papers, Glen Canyon Ser. No.7, Dept. of Anthropology, Univ. of Utah. $226 \mathrm{p}$.

This is a collection of papers on clen Canyon before its impoundment as Lake Powe 11 .

Woodbury/ Utah/ Arizona/ freshwater/ river/ general/ review/ 


\author{
SECTION 1.1 \\ RELATED HABITAT PAPERS: ARIZONA
}

Anderson, E.R. and Pritchard, D.W. 1951. Final Report: Physical limnology of Lake Mead. U.S. Nav. Electronics lab. Rept.

No. 258 . $153 \mathrm{p}$.

This report describes the physical limnology of Lake Mead from cruises taken in 1948-1949. Nothing on algae.

Anderson/ Nevada/ Arizona/ freshwater/ lake/ physics/ not algae/

Bryan, K. 1925. The Papago Country, Arizona. A geograpic, geologic, and hydrologic reconnaisance with a guide to desert watering places. U.S. Geol. Surv. Water-supply Pap. No. $499.436 \mathrm{p}$.

This is a description of watering places in southwestern Arizona. Nothing on algae.

Bryan/ Arizona/ spring/ wells/ pond/ hydrology/ guidebook/ not algael

Cole, G.A. and Whiteside, M.C. 1965. Kiatuthlanna - A I imnological appraisal. I. Physical factors. Plateau 38 : $6-16$.

Two small, saline ponds in Apache County, Arizona, are at an archeological site known by the zuni name kiatuthlanna. Both show dichothermy in early summer, but circulate later when evaporation reduces their volumes. Addition of dilute surface water during winter probably re-establishes stratification. The temporary monimolimnion of Red Pond contains purple sulfur bacteria. Nothing on algae.

Cole/ Arizonal saline/ pond/ physics/ not algael

Eisher, S.G. and Minckley, W.L. 1978. Chemical characteristics of a desert stream in flash flood. J. Arid Environments 1: $25-33$.

Changes in selected chemical parameters during a single flash flooding event on sycamore Creek, Arizona, are described.

Particulate materials increase markedly during flash flooding to exceedingly high levels (to $55 \mathrm{~g} 1-1$ ). Peak concentrations occur at the leading edge of the initial flood wave. Total 


\begin{abstract}
dissolved substances decline regularly during flooding by dilution and fail to respond to minor pulses in discharge. Selected dissolved constituents such as nitrate and phosphate generaliy increase during flash flooding, the pattern being similar to that of suspended materials, suggesting leaching of particulates in stream water as the major source of these nutrients.
\end{abstract}

Eisher/ Arizona/ freshwater/ stream/ chemistry/ not algael

Grimm, N.B., Fisher, S.G. and Minckley, W.L. 1981. Nitrogen and phosphorus dynamics of hot desert streams of southwestern U.5.A. Hydrobiologia 83:303-312.

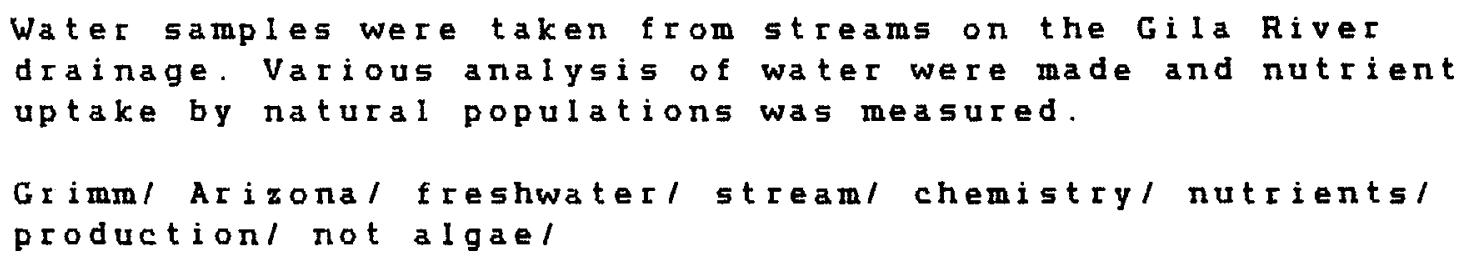

Hely, A.G. 1969. Lower Colorado River water supply - its magnitude and distribution. U.S. Geol. Surv. Prof. Pap. No. $486-D$.

HeIy/ Californial Arizona/ river/ hydrologyl not algael

Irelan, B. 1971. Salinity of surface water in the lower Colorado River - Salton Sea area. U.S. Geol. Surv. Prof. Pap. No. $486-E$.

Irelan/ CaIifornial Arizonal Salton Sea/ salinel chemistryl not a I gael

Olmsted, F.H., Loeltz, O.J. and Irelan, B. 1973. Geohydrology of the Yuma area, Arizona and California. U.S. Geol. Surv. Prof. Pap. No. $486-\mathrm{H}$.

Olmsted/ Californial Arizona/ hydrology/ not algael

\footnotetext{
Feale, A.C. 1886 . Lists and analyses of the mineral springs of the United States. Bull. U.5. Geol. Surv. No.32, Washington, D.C. $235 \mathrm{p}$.

This paper lists the locations and the status of many saline
} 
springs in the United states, especially in the West. Nothing on a lgae.

Peale/ Idahol Utah/ Arizona/ New Mexicol Californial Oregon/ Montana/ Wyomingl Nevadal Coloradol salinel springl chemistryl general/ guidebook/ not algael

Rampe, J.J., Jackson, R.D. and Sommerfeld, M.R. 1981. Fhysicochemistry of the Upper Gila Watershed. I. San Francisco River and CIifton Hot Springs. J. Ariz. - Nev. Acad. Sci. 16: 1-6.

The San Erancisco River and CIifton Hot Springs were investigated chemically from January 1977 to March 1978. The River was well-oxygenated and consistently alkaline throughout the study area. The upper san francisco River had a mean TDS of $396 \mathrm{mg} \mathrm{I}^{-1}$ with the chemistry dominated by calcium and magnesium bicarbonate, and considerable amounts of sodium and chloride. Downstream from Clifton Hot Springs the River doubled in TDS and was chemically dominated by sodium and calcium chloride. The concentration of the nutrient phosphorus (as phosphate) was variable, but high throughout the River and presumed to be primarily edaphically derived. Ammonia and nitrate nitrogen concentrations, however, were low. Dissolved trace elements were a 50 generaliy low, but variable in the River. Manganese occasionaliy exceeded water quality standards at the two sampling sites below Cifton Hot Springs. Clifton Hot Springs had an average temperature of 43 C and was highly mineralized with a TDS over $9000 \mathrm{mg} \mathrm{I}^{-1}$. The input of Clifton Hot Springs into the River significantly increased the TDS, sodium, calcium, magnesium, potassium, chloride, fluoride, and manganese content of the River. Based on changes in the chloride ion composition of the river as it flows past Clifton Hot Springs, the discharge of the Springs was calculated to average about 74 I $\sec ^{-1}(2.6$ cfs) and contribute about 21,400 metric tons of $5 a 1$ ts to the San Francisco River annualiy.

Rampe/ Arizona/ freshwater/ saline/ river/ springl chemistry/ not a Igael

Stull, E.A. and Kessler, S.J. 1978. Major chemical constituents of Arizona Lakes. J. Ariz. - Nev. Acad. Sci. 13: 57-61.

The 23 lakes surveyed for this study are chemically diverse, in part due to Arizona's arid climate. Proportions of sodium to calcium increase with increasing salinity, and lakes of both thalassiohaline and athalassionhaline evaporation series are found. Geographic patterns of climate are correlated with the concentration of major chemical constituents, and a high proportion of the variance in chemical concentration can be described by variables of climate and watershed morphology. 
Stull/ Arizona/freshwater/ saline/ lake/ chemistry/ not algael 


\section{SECTION 2.0}

\section{ALGAL PAPERS: CALIFORNIA}

Armstrong, W.P. 1982. Dangeardinelia: In every drop of brine. Enviconment Southwest, San Diego Nat. History Museum No.499: $18-20$.

A popular account describing the distribution of this unusual a $1 \mathrm{ga}$ in brine samples from eastern California and Nevada. This a Iga has affinities with the Prasinophyceae of the Chrysophyta. Celis and habitats where they are found are iliustated.

Armstrong/ California/ Nevada/ salinel lake/ pond/greenalgael il Iustationsl

Arnal, R.E. 1961. Limnology, sedimentation, and microorganisms of the Salton Sea, California. Buli. Geol. Soc. Am. 72: $427-428$.

This paper mentions algae found by others and is primarily a geological paper. Blooms of foraminifera feeding on algal blooms are discussed.

Arnal/California/salton Sea/saline/lake/diatom/ blue-green algae/ chemistry/geology/ bloom

BIinn, D.W. 1971. Autecology of a filamentous alga, Ctenocladus circinnatus (Chlorophyceae) in saline environments. Can. J. Bot. $49: 735-743$.

Six highly saline habitats in arid regions of British Columbia, Nevada, and California with the chaetophoralean Ctenocladus circinnatus Borzi were investigated to characterize the unique environment of this alga. Seasonal patterns within three of these habitats were analyzed to reveal those parameters determining the restricted distribution of ctenocladus. Sodium was the dominant cation in combination with any major anion, $5 u c h$ as sulate, carbonate and bicarbonate. Seasonal salinity fluctuations of the water solutions were large ( $10->100$ milimhos). Ctenocladus tolerated these high salinities and temperatures (-3 to 28 C) 35 akinetes formed early in the summer and they survived as akinetes until dilution of the water solutions the next spring. The period for optimum vegetative development was short $(6-12$ weeks) because of an increase in salinity and temperature of the waters. Akinete germination in the lab was optimal between 9 and 26 C and temperatures above 34 c destroyed akinetes: Conversely, the freezing of akinetes produced no adverse affects. Laboratory studies showed germination and 
vegetative developrant retarded at pH below B. o with akinetes destroyed below 7.0. Light is essential for germination with low I ight intensities ( 214 lux) stimulating germination. Light intensities above 12000 lux destroyed akinetes within 5 days. Sexual reproduction in both the tield and laboratory was absent. The significance of the akinete and lack of sexual reproduction are correlated with laboratory and field data and the restricted distribution of Cterociadus.

BIinn/ British Columbia/ California/ Nevada/ saline/ lake/ pond/ green algael chemistryl enviconmental factors/ ecologyl

BIinn, D.W. and Stasn, J.R. 1970. Distribution and taxonomic reappraisal of chenocladus (Chiorophyceae: Chaetophorales).

J. Phycol. 6: 101-105

The distribution of the rare filamentous green alga ctenocladus Borzi was examined on a world-wide basis. All the collection sites are restricted to specific inland habitats. Most of these locations are in arid regions of North America with a few scattered sites in peru, Sicily, and Siberia. This alga has been referred to 2 genera, either Cterocladus or Lochmiopsis Woronochin $\&$ Popowa, Lor the past 45 years. Based on field observations, laboratory cultures, and herbarium material, Lochmiopsis is considered synonymous with Ctenocladus. The response of vegetative cell dimensions to seasonal changes (i.e., osmotic potential and temperature) in 3 saline habitats in British Columbia study, along with laboratory dilutions of natural saline waters, showed that cell dimensions are not valid criteria for separating species of ctenocladus as proposed by some authors. Consequently Ctenocladus is considered a monotypic genus with physiological variants responding to seasonal environmental conditions. (In North America this alga has been collected at Mono Lake and Borax Lake, California; Green Fond and Red Fond, Arizona; Abert Lake, oregon and at several locations in British Columbia. Isolates from the latter locations are illustrated).

BIing/ British Colurabial Californial Oregon/ Arizonal Nevadal salinel lake/ pond/ green algae/ taxonomyl illustrationsl

Brues, C.T. 1928. Studies on the fauna of hot springs in the western United 5 tates and the biology of thermophilous animals. Proc. Ant Acad. Arts Sci. 63: 139-228.

This paper is a very short discussion of blue-green algae in hot springs. It primari igy provides data on invetebrate fauna of hot springs in saveral states. Locations of each are given.

Brues/ California/ Navada/ New Mexicol Utah/ saline/ freshwater/ springl biue-green algael zoologyl 
Cameron, R.E. 1969 . Abundance of microflora in soils of desert regions. Tech. Rept. 32-1378, Jet Propul. Lab., Pasadena, California. $16 \mathrm{p}$.

Surface soils were collected by aseptic techniques from cold, polar, hot volcanic, and high mountain deserts, and were analyzed for physical, chemical, and microbiological properties. soils showed a wide range of properties but were generally greyish, yel lowish, or brownish sands, low in organic matter and cation exchange capacity. There were detectable concentrations of water-soluble ions, and pH values above 7.9 , except in volcanic areas. Total microbial abundances ranged from aero (undetectable) to >109 $\mathrm{gm}^{-1}$ of soil. Aerobic and microaerophilic bacteria were most abundant, followed by algae and molds. The anaerobic bacteria were generally least abundant or undetectable. Predominant microflora included Bacillus spp., soil diptheroids, Schizothrix spp. and other oscillatrioid blue-green algae, Streptomyces spp., Peniciliium spp., and Aspergillus spp.

Cameron/ California/ Oregon/ Arizonal New Mexicol soill blue-green algael green algael

Cameron, R.E. and BIank, G.B. 1965. Soil studies-microflora of desert regions. VIII.Distribution and abundance of desert microfiora. Jet Propul. Lab. Space Progr. Summ. No.37-34, VOI. IV: $193-209$.

This paper lists a few algae that came up in cultures of soil from the california desert.

Cameron/ California/ soil/blue-green algael greenalgael cuItures/

Cameron, R.E. and BIank, G.B. 1966. Desert algae: Soil crusts and diaphanous substrata as algal habitats. Jet propul. Lab. Tech. Rept. No.32-971, p1-41.

The most favorable habitats in desert soils occur in algal and lichen soil crusts, and on the undersurface of translucent or transparent material partialiy imbedded in the soil sureace. Algal abundance is increased and ecological factors are much less restrictive in these ecological niches than in the surrounding desert soil. Insolation is modified, more moisture is retained, dessication is reduced, and organic matter accumulations are noticeable. Characteristics of transiucent materials, such as white or milky quartzand chalcedony, which are partially imbedded in the surface of desert soils, permit the existence of mesophilic algal inhabitants, such as species 
of coccoid and blue-green algae, that do not normally occuras components of xeric soil populations. Other species are cosmopolitan forms occurring in a wide range of environments, including habitats at low or high elevations in hot or cold deserts. The probable occurrence of a number of translucent and transparent minerals in extraterrestrial soils and other geological materials may also provide a favorable ecological niche or microenvironment for organisms and associated organic matter in an otherwise harsh macroenvironment.

Cameron/ Arizona/ California/ Nevada/ freshwater/ saline/ soil/ diaphanous substrata/ blue-green algae/ green algae/ review/ i I I ustationsl

Cameron, R.E., Morelii, F.A. and BIank, G.B. 1965 . Soil studies - desert microflora. VI. Abundance of microflora in an area of soil at White Mountain Range, California. Jet Propul. [ab. Progr. Summ. No.37-32, Vol. IV: 212-214.

This paper describes abundance of algae by serial dilution method.

Cameronl Californial soil/ blue-green algael culturesl

Carlson, J.S., Everett, L.G. and Qashu, H.K. 1971. Chemical and biological patterns in the lower Colorado River system. Unpub. Rept. Univ. of Arizona. Unpaged.

Results presented in this paper are intended: 1 ) to stimulate interests for discussions of abiotic-biotic interactions in the Colorado River System, 2) to identify some hydro-biological patterns to guide our current research program, and 3 ) to identify appropriate analytic procedures and sampling. Spatial and temporal variabilities in system properties are real and considered in the current research program on Lake Mead. These changes are caused by the nature of changes in inputs--water, sediments, solutes, sewage effluent, and other recreational products. Degradation of the phytoplankton and zooplankton were observed and changes in species dominance was illustrated across Lake Mead and in other parts of the Lower colorado River system. causes of these changes are speculative at this time and may be associated with changes in concentrations of essential nutrient species. Limiting amounts of some essential micro-nutiients were documented in areas showing undesirable changes in plankton species. The increase in many ions may in fact cause the absence of changes in the biota or serve to enhance the limiting effects of low concentrations of micronutients.

CarIson/ Utah/ Arizona/ Nevada/ California/ freshwater/ blue-green algael diatom/ green algael dinoflagellatel zoologyl chemistryl 
Carpelan, L. 1961. Phytoplankton and plant productivity. In Walker, B.W., ed. The Ecology of the Salton Sea, California, in Relation to the Sportfishery. Calif. Dept. Fish and

Game, Fish. Bul1. No.113:33-42.

Drawings showing monthiy changes in various algal groups in 1955 and 1956 are given. The species are marine. This paper gives some measurements of photosynthesis by the light and dark bottle oxygen technique and shows productivity to be about four times that of fertile coastal water - about 2.7 tors dry weight $/$ acre/year.

Carpelan/ California/ Salton Sea/ salinel lake/ green algael diatom/ blue-green algael dinoflagellatel illustrationsl successionl productionl

Carpelan, L.H. 1958. The Salton Sea. Physical and Chemical Characteristics. Limnol. Oceanogr. 3: 373-386.

This paper includes some discussion of algal occurrence, but it is mostly on physics and chemistry. Chemical analysis is included.

Carpelan/ Californial Salton Seal salinel lakel diatom/ blue-green algael dinofiagellate/ Euglenophytal Chrysophytal chemistry/ physics/ nutrients/

Chapian, D.J. 1982. Investigation on the salinity tolerance of a diatom and green alga isolated from Mono lake. Paper presented at "Mono Lake: An Ecosystem in Transition" Symposium, University of California, Santa Barbara, May 5-7, 1982 .

The author investigated effects of 5 alinity on two algae isolated from Mono Lake. The present lake salinity is about 90 parts per thousand; increased salinity to 198 parts per thousand lowered the growth rate of a green algabut not that of a diatom. The green alga is tolerant of salinity up to 135 parts per thousand. Growth was si ightly reduced by increases in As or F, but the species are generaliy tolerant of these ions.

Chapmanl Californial saline/ lake/ Mono Lake/ diatom/ green algael cultures!

Cole, G.A. 1963. The American Southwest and Middle America. In Frey, D.G., (ed). Limnology in North American, Chpt.14, p. 393-434. Univ. of Wisc. Press, Madison, Wisconsin. 
This is a good general review of al aquatic habitats in the American Southwest and Middle America (Meaico and Central Aretica). Descriptions by area and habitat are provided. The author includes some comparitive chemical data. There are various algae mentioned in the text.

Cole/ Californial Nevadal Arizonal Utah/ New Mexicol Colorado/ Texas/ 5alinel freshwater/ lake/ stream/ springl pond blue-green algae/ green algae/ diatom/ chemistry/ general/ $r \in v i$ ew $/$

Coville, F.V. 1893 . Botany of the Death Valley Expedition. Contr. U.S. Nat. Herbarium 4: $1-363$.

A very smali listing of algal species and genera is included on p. 232. There is also some data on the salt concentration of Owens Lake, California, before any diversion of the Owens River.

Covilief Californial salinel freshwater/ lake/ spring/ snowfields/ green algael blue-green algael chemistryl

Drouet, F. 1943. Mysophyceae of eastern California and western Nevada. Field Mus. Nat. Hist., Bot. Ser.20:145-177.

This paper includes a good description of many species of blue-green algae and their locations.

Drouet/ California/ Nevadal freshwater/ saline/ spring/ stream/ soil/ pool/ Iake/ blue-green algae/ species Iist/

Durrell, L.W. 1962. Algae of Death Valley. Trans. Am. Microsc. Soc. 81:267-273.

Twenty-three species are listed with blue-green algae being the most common. Of these, 16 species occurred in the soil.

Durreli/California/ soil/blue-green algae/green algae/ species listl

Edmondson, W.T. 1963. Pacific Coast and Great Basin. In Erey, D.G., (ed). Limnology in North America, Chpt. 13, p.371-392. Univ, of Wisc. Press, Madison, Wisconsin.

This is a generai review of the limnology of this area. Some listings of algae are included. 
Edmondson/ California/ Oregon/ Washington/ Nevada/ Utah/ salinel freshwater/ lake/ river/ pond/ chemistry/ general/ review/

Eskew, D.L. and Ting, I.P. 1977. Nitrogen fixation in a Colorado Desert environment. Suppl. to plant Physiol. 59(6):5B.

Blue-green algal crusts showed $N$ fixation (acetylene reduction measurements ).

Eskew/ California/ soil/ blue-green algae/ nitrogen fixation/

Everett, L.G., Carlson, J.5. and Qashu, H.K. 1971 . Chemical and biological patterns in the lower Colorado River system. J. Ariz. Acad. Sci. 8:91-94.

The abundance of diatoms and green algae decreased in a downstream dicecton from Lake Powell to Lake Mead to Lake Havasu. These algae were replaced by filamentous blue-green a lgae and dinoflageliates. There is only speculation as to why these changes occur - possibly because of water chemistry changes or changes in grazing pressure.

Everett/ Arizona/ Nevada/California/Utah/ treshwater/ river/ diatom/ green algael dinoflagellatel blue-green algael zoologyl chemistry/ nutrients/

Gaines, D. and the Mono Lake Committee. 1981. Mono Lake Guidebook, Mono Lake Committee/ Kutsavi Books, Lee Vining, California, $113 \mathrm{p}$.

This is a general guidebook to Mono Lake - its geology, history, biology, chemistry and future.

Gaines/California/ MonoLake/ saline/ lake/ chemistry/ guidebook/ reviewl generall

Hart, J. 1981. Hiking the Great Basin. Sierra Club Books, San Francisco. $372 \mathrm{p}$.

There is little mention of algae but this book is a good general detailed guide to the Great Basin, including parts of eastern California, western Utah, southeastern Oregon, and most of Nevada. Some warm and/or saline springs, creeks and lakes where algae should be found are mentioned.

Hart/CaIifornial Utah/ Nevada/ Oregon/ freshwaterl salinel spring/ stream/ lake/general/guidebook/ thermal habitat/ 
Hunt, C.B. and Durcell, L.W. 1966. Plant ecology of Death Valley, California, with a section on distribution of fungi and algae. U.S. Geol. Survey Frof. Pap. No.509. p1-68.

Higher plants grow up to $6 \%$ salinity, algae to $8 \%$, fungi to 10-12\%, bacteria to $15 \%$. Algae growing under transparent rocks - "microgreenhouses"- are noted. Nearly all the species are biue greens.

Hunt / Californial saline/ lakel stream/ soil/ ground water/ blue-green algael green algael ecology/distributionl

Keminerer, G., Bovard, J.E., and Boorman, W.R. 1923. Northwestern lakes of the United 5 tates: Biological and chemical studies with reference to possibilities in production of fish.

Fish. Bull., U.S. Nat. Mar. Fish. Serv. 39: 51-140.

This is mostly a discussion of fish and invertebrates. There are some algal counts. The lakes are not really in the desert.

Kemmerer/ Oregon/ Washington/ Idaho/ Californial freshwater/ lake/ blue-green algael green algaeldiatom/ chemistry/

Krumbein, W.E. and Potts, M. 1975. Girvanella-like structures formed by plectonema gloephilum (Cyanophyta) from the Borrego Desert in Southern California. Geomicrobiol. Journ. 1: $211-217$.

An example of a recent tubiform fossil Girvanella is reported froma transitory, freshwater flash-spring, in an area of the Borrego Desert, near San Diego, California. It occurs as the preserved, calcite-impregnated sheath of the blue-green alga Plectonema gloephilum Borzi. In size and form, the fossil is identical to the first specific description of a recent Girvanella. The data presented give strong support to the idea of specificity of calcification in some blue-green algae.

Krumbein/ California/ freshwater/ spring/ blue-green algae/ il Iustrationsl

La Rivers, I. 1978. Algae of the Western Great Basin. Bioresources Center, Desert Research Institute, University of Nevada system, Reno, Nevada. $390 \mathrm{p}$.

This book is a reasonably complete description of al a agae occurring in Nevada (particularly the western part of the state) 
and in eastern California; some algae are recorded from Arizona. The book contains keys and illustrations and discusses the history of algal research in these areas. The book has a glossary and index. Locations are given for each species. Chlorophyta, Euglenophyta, Chrysophyta (with diatoms), Cyanophyta, and Rhodophyta are included. This is a definitive work on desert a Igae.

La Rivers/ Nevada/ Califorgia/ Arizona/ saline/ freshwater/ lake/ soil/ pond/ stream/ spring/ blue-green algael greenalgael Euglenophytal diatom/ Chrysophyta/ general/ taxonomy/ i 11 ustrationsl

Mason, D.T. 1967. Limnology of Mono Lake, California. Univ. of Calif., Publ. in Zoology 83: 1-110.

This is a general review of the limology of Mono Lake with sections on physics, chemistry and biology. The lake has a salinity about twice that of seawater. The algae include a diatom (Nitzschia), green algae (Dunalielia, Chlamydomonas, Pamellococcus) and occasionaliy a blue-green (Spirulina). A diatom bloom was recorded in late september, 1964. The diatom is generaliy more abundant than other algae. In situ productivity (March 1960) was $8.6 \mathrm{gm} \mathrm{C} \mathrm{m}^{-2}$ day with a photosynthetic efficiency of $2.7 \%$. An enrichment experiment did not significantly enhance photosynthesis (p.84) but in another experiment Mg stimulated chlorophyll increases. The lake is full of brine shrimp which in turn support a gull population (Indians used to gather brine shrimp for food). R. A. Lewin cultured the diatoms "Diatoms Mono 2,4 and $6 "$ and a blue-green, Schizothrig calcicola. Generally this paper contains sketchy and preliminary information indicating much need for further work, as the author suggests.

Mason/ California/ Mono Lake/ saline/ lakel chemistry/ physicsl diatoml green algael blue-green algael generall review/ blooml

Melack, J.M., Liang, Y. and Lenz, E.H.1982. Ecological responses of the plankton of Mono lake to increased salinity. Paper presented at "Mono Lake: An Ecosystem in Transition" Symposium, University of California, Santa Barbara, May $5-7,1982$.

Microcosm experiments in which 5 alinity slowly increased by $40 \%$ are described. The paper mainly describes the effects on Artemia. The seasonal plankton cycle in Mono Lake was presented oraliy (not in abstract). Green algae are abundant in the winter; Artemia hatch in March and graze down algae in epilimion in the summer (algae still abundant in hypolimnion); Artemia are reduced in the fall and algae again become abundant. 
Melack/ Californial salinel lake/ Mono Lakel green algael cultures/

Miller, R.R., Soltz, D.L. and Sanchez, P.G. 1977. Eishes and Aquatic Resources of the Death Valley system, CaliforniaNevada, $1878-1976$. A Bibliography. U.S. Dept. Interior, Nat. Park Serv. 27 p.

This is a general bibliography of biota and water in Death Val I ey.

Miller/ California/ Nevada/ saline/ freshwater/ bibliography/

Naiman, R.J. 1975. Food habits of the Amargosa pupfish in a thermal stream. Trans. Am. Fish. Soc. 104:536-538.

Food habits of an Amargosa pupfish (cyprinodon nevadensis amargosae) population inhabiting a thermal stream were examined at monthly intervals from January 1972 to April 1973 . Little variation in foods eaten during the year was observed in the 218 specimens examined. The diet was almost entirely a migture of blue-green algae and detritus. Invertebrates were only a minor component due to their scarcity in the stream. The smallest fishes consumed some invertebrates but this habit changed as the relative length of the digestive tract rapidiy increased.

Naiman/ California/ freshwater/ stream/blue-greenalgael thermal habitat l

Naiman, R.J. 1976. Primary production, standing stock, and export of organic matter in a Mohave Desert thermal stream. Limnol. Oceanogr. $21: 60-73$.

The water of a thermal artesian stream (Tecopa Bore) in the Mohave Desert near Death Valley, California, issues from the ground at 47.5 C and cools B-12 C before leaving a study area $300 \mathrm{~m}$ long. Growth occurs year round because of the high water temperature. Pupfish are the dominant herbivores; aquatic invertebrates are rare. The $11,065 \mathrm{kcal} \mathrm{m}^{-2}$ annual input of energy to the biological system is totally accounted for autochthonous primary production. About 718 kcal mof organic matter is stored within the system in the form of algal mats and detritus and has a turnover time of about 23 days. The bulk of the annul primary production ( $81 \%$ ) is channeled into respiration and decomposers; $9 \%$ is lost as dissolved organic carbon and $4 \%$ as drift of particulate organic matter. Pupfish (Cyprinodon nevadensis amargosae) feed on algae and detritus, ingesting $17 \%\left(1,878 \mathrm{kcal} \mathrm{\textrm {m } ^ { - 2 } \mathrm { year }}-1\right.$ ) of the annual primary production, of which $119 \mathrm{kcal} \mathrm{m}^{-2}$ year is deposited in 
growth.

Naiman/ California/freshwater/ stream/ blue-green algael diatom/ chemistry/ production/ thermal habitatl

Naiman, R.J. 1976. Productivity of a herbivorous pupfish population (Cyprinodon nevadensis) in a warm desert stream. J. Eish Biol. $9: 125-137$.

This is mainly about fish in Tecopa Bore, California, but there is some mention of their food - blue-green algae and diatoms.

Naiman/ Californial freshwater/ stream/ blue-green algael diatom/ thermal habitat/ zoology/

Naiman, R.J. 1979. Preliminary food studies of Cyprinodon macularius and Cypcinodon nevadensis (Cyprinodontidae). Southwest. Nat. 24:538-541.

The author examined gut contents of pupfish from the salton sea, Armogosa River and Saratoga Springs. Algae are not as important a food as detritus and invertebrates.

Naiman/ California/ Salton Sea/freshwater/ saline/pool/ riverl lakeldiatom/ blue-green algael zoologyl

Naiman, R.J. and Gerking, S.D. 1975. Interrelationships of light, chlorophyll, and primary production in a thermal stream. Verh. Internat. Verein. Limnol. 19: 1659-1664.

Chlorophyll and production were not correlated; chlorophyl and light were. Light does not inhibit production due to self-shading in algal mats.

Naiman/ CaIifornia/freshwater/ stream/production/diatom/ blue-green algaef chlorophyll'

Philips, K.N. and Van Denburgh, A.S. 1971. Hydrology and geochemistry of Abert, Summer, and Goose Lakes, and other closed-basin lakes in south-central Oregon. U.S. Geol. Surv. Prof. Pap. No.502-B. 86 p. 2 plates.

This paper describes the hydrology and chemistry of several desert lakes in Oregon and northeastern California. There is some mention of algae in Lake Abert. 
Phillips/ Oregon/ California/ saline/ freshwater/ Iake/ blue-green algael green algael diatom/ chemistryl nutrients/

Scholl, D.W. and Taft, W.H. 1964. Algae, contributors to the formation of calcareous tufa, Mono Lake, California. J. Sed. Petrol. 34: 309-319.

The prevailing view is that tufa deposition at Monolake, east central California, is dominated by inorganic processes. This paper asserts that algae are important contributors to the formation of lithoid tufa at the lake, and probably also of other varieties. Calcium carbonate as calcite, aragonite, and high-magnesium calcite has been deposited at Mono Lake in the form of pinnacled masses of tufa. These structures formed (and are still forming) about the orifices of springs issuing from beneath the highly-alkaline waters of this lake. The lake is a desiccated remint of a formerly much larger pleistocene water body. Lowering of the lake level has exposed many pinnacles, two of which were examined for this study. One of these pinnacles issues spring water through its sides and from a sumit crater. The other structure is a dry pinnacle. A calcareous algal mat (1-3 mm thick) is attached to the sides of the summit-spring pinnacle beneath water cascading from its summit or exuding through its flanks. The algal mat is partialiy embedded in a thin (1-5 mm) layer of relatively dense lithoid tufa. The dense I ithoid tufa sheathes a more porous lithoid tufa which forms the bulk of the summit-spring pinnacle. The mat is calcareous owing to an abundance of microcrystalline and pelletal calcite immeshed between the thalli of the filamentous algae cmostiy bIue-greens) which constitute the mat. Organic-rich microcrystalline calcite bearing abundant remains of filamentous a lgae form the underlying layer of dense lithoid tufa. Porous I ithoid tufa, which forms the bulk of most pinnacles near the present shoreline of the lake, contains about equal proportions of organic-rich microcrystaline calcite or aragonite and coarser sparry calcite. In the summit-spring pinnacle the finecrystaline carbonate is calcite, but it is aragonite in the porous lithoid tufa of the dry pinnacle. The microcrystalline cabonate of both pinnacles contains remains of filamentous a Igae; loosely packed groups of spherical bodies, which are probably coccoid algal cells, are also found in the porous lithoid tufa of the summit-spring pinnacle. Primarily because is lga are intimately associated with freshly-deposited tufa, and because organic-rich microrrystalline calcite and aragonite of older deposits of lithoid tcfa are rife with algal remains, precipitation of lithoid tufa is probably botanically induced. Most I ikely precipitation results from the photosynthetic withdrawal of carbon dioxide, which lowers the solubility of calcium carbonate in close proximity to the plants. About two-thirds of the sparry calcite has formed in close association with the microcrystalline carbonate and is also regarded as organically deposited. Some of the spar, however, has been deposited as a cavity Iining or filling and therefore is 
probably of inorganic origin. The occurrence of high-magnesium calcite in nodose tufa of the dry pinnacle implies that this unusual and somewhat uncommon variety was organically precipitated.

Scholl/ California/ Mono Lake/ saline/ Lake/ blue-green algae/ geology $l$

Switzer, L. 1980. Spirulina: The Whole Food Revolution. Proteus Corp., Berkeley, California, $102 p$.

This is a good general description of all aspects of spirulina mass culture in the Imperial Valley of California, in Mexico, and in Thailand. Nutrient and food value is described. Recipes are provided. The book includes a general introduction to microalgae and their mass culture. Many claims for spirulina as the food of the future are given, but it is not a badly unbalanced book.

Switzer/ California/ pond/ blue-green algae/ general/ review/ illustrationsl culturesl

Thomas, W.H. 1972. Observations on snow algae in California. J. Phycol. B: 1-9.

A Igae that impart a red color to snowfields are rather common in California. Red snow occurs mainly in the Sierra Nevada at altitudes of $10,000-12,000 \mathrm{ft}(3050-3660 \mathrm{~m})$ and can occur at high altitudes where snow persists in other parts of the state. The distribution in the sierra was similar in 1969 and 1970 , contrasting snowfall years. Colored snow was found from May to october in old, wet snowfields. The predominant color was red and occurred as surface patches in depressions in the snow. The color could extend as deep as $30 \mathrm{~cm}$ below the snow surface. Algae in the snowfields of the Tioga Pass area (Sierra Nevada) were Iarge, red, spherical celis of Chlamydomonas nivalis. No other algae were seen. Their distribution, as measured by cell numbers and chlorophyli A, was patchy. Algal cells and chlorophyli A were mainiy distributed at or near the soil surface but extended down to a depth of $10 \mathrm{~cm}$. Light intensity was greatly attenuated by snow, but enough light for photosynthesis was found at $50 \mathrm{~cm}$ below the surface. Nutrient content of one snow sample was very low. The populations were very actively photosynthetic and took up as much as $65 \%$ of added $14 \mathrm{CO}_{2}$ in only $3 \mathrm{hr}$. It was tentatively concluded that carbon dioxide limits in situ photosynthesis. Photosynthesis was inhibited by melting snow samples. Rough calculations of the growth rate suggested in situ generation times of only a few days for these algae.

Thomas/ California/ freshwater/ snowfields/ green algae/ maps/ 
WaIlace, A., Romney, E.M. and Hunter, R.B. 1978. Nitrogencycle in the northern Mohave Desert: Implications and predictions. In West, N.E. and Skujins, (eds). Nitrogen in Desert Ecosystems, US/IBP Synthesis Series No.9, Dowden, Hutchinson, and Ross, strandsburg, Pennsyluania. p.207-218.

Nitrogen cycle in the desert is discussed. There is some mention of blue-green algae and lichens as $N$ fixers.

Wallace/California/ soil/ blue-green algae/lichens/ nitrogen cycie/ nitrogen fixation/

Young, D.R. 1970. The distribution of cesium, rubidium, and potassium in the quasi-marine ecosystem of the salton sea. Ph.D. Thesis, Univ. of Calif., San Diego. $213 \mathrm{p}$.

This thesis is mainly on metal distributions among the higher levels of the food web. Species of algae found in samples are mentioned. Carbon fixation was 0.1 to $1.9 \mathrm{gm}$ m day.

Young/California/ Salton Sea/ salinel lakeldiatom/ dinoflageliate/ green algae/ blue-green algael chemistry/ species list/ productionl 


\section{SECTION 2.1 \\ RELATED HABITAT PAEERS: CALIFORNIA}

Brues, C.T. 1932. Eurther studies on the fauna of North American hot springs. Am. Acad. Arts and Sci. 67: 186-303.

There is no information given on algae, but there are good descriptions of numerous hot $5 p$ ings in the west.

Brues/ Nevada/ California/ Utah/ saline/ freshwater/ spring/ zoology/ thermal habitat/ not algae/

Carpelan, L.H. 1961 . Physical and chemical characteristics. In Walker, B., (ed). The Ecology of the Salton Sea, California, in Relation to the Sportfishery. Calif. Dept. Fish and Game, Fish BuIl. No.113, p.17-32.

The author lists the chemical composition of 5 alton sea water and also lists the water temperatures.

Carpelan/ California/ Salton Sea/ galine/ lake/ chemistry/ not a I gael

Foshag, W.E. 1926. Saline lakes of the Mohave Desert region. Econ. Geol. 21:56-64.

Nothing on algae, but there is a good description of several saline lakes in Mohave Desert of California.

Foshag/ Californial saline/ lake/ geology/ not algael

Gale, H.S. 1915. Salines in the Owens, Searles, and Panamint Basins, southeastern California. Bull. U.S. Geol. Surv. No. 580, p. $251-323$.

Nothing is given on algae. Early analytical data on chemical composition of these lake waters is recorded.

Gale/ California/ saline/ lake/ chemistry/ not algael

HeIy, A.C. 1969. Lower Colorado River water supply - its magnitude and distribution. U.S. Geol. Surv. Frof. Pap. No. $486-D$. 
Hely/ California/ Arizona/ river/ hydrology/ not algael

Irelan, 8. 1971. Salinity of surface water in the lower Colorado River - Salton Sea area. U.S. Geol. Surv. Prof. Pap. No. $486-E$.

Irelan/California/ Arizona/ Salton Sea/ saline/ chemistryl not a lgael

McDonald, C.C. and Loeltz, O.J. 1976. Water resources of the lower Colorado River - Saltor Sea area as of 1971 : Summay report. U.S. Geol. Surv. Prof. Pap. 486-A.

MeDonald/California/Salton sea/ saline/ lake/ river/ hydrology/ chemistry/ review/ not algael

Olmsted, E.H., Loeltz, O.J. and IreIan, B. 1973. Geohydrology of the Yuma area, Arizona and California. U.S. Geol. Surv. Prof. Pap. No. $486-\mathrm{H}$.

OInsted/California/ Arizona/ hydrology/ not algael

Peale, A.C. 1886 . Lists and analyses of the mineral springs of the United States. Bull. U.S. Geol. Surv. No.32, Washington, D.C. $235 \mathrm{p}$.

This paper lists the locations and the status of many saline springs in the United states, especially in the West. Nothing on a lgae.

Peale/ Idahol Utah/ Arizona/ New Mexicol Calieornial Oregon/ Montana/ Wyoming/ Nevada/ Colorado/ salinel springl chemistry/ general/guidebook/ not algael

Russe11, I.C. 1889. Quaternary history of Mono Valley, California. Annu. Rept., U.S. Geol. Surv. B: 267-394.

This is a tine early geological survey of the Mono Lake Basin. It is beautifuliy illustrated with maps and I ine drawings.

Kussel1/California/ MonoLake/ saline/ lake/ chemistry/ geology/ illustrations/ not algael 
Smith, G.I. 1973. Subsurface stratigraphy and composition of saline bodies, Searles Lake, California: a preliminary report. U.S. Geol. Surv. Open-File Rept. No.265, California Div. Mines and Geology, Sacramento. $122 \mathrm{p}$.

Smith/ Californial saline/ lake/ chemistry/ hydrologyl not algael

Sturrock, Jr., A.M. 1978. Evaporation and radiation measurements at Salton Sea, California. U.S. Geol. Surv. Water-Supply Pap. No.2053.26p.

This paper gives some solar radiation data for salton sea.

Sturrock/ California/ Salton Sea/ saline/ lake/ physics/ not algael

Waring, G.A. 1915. Springs of California. U.S. Geol. Surv. Water-Suppiy Pap. No.338. 410 .

This paper describes many springs in California and includes some chemical analyses.

Waring/ California/ freshwater/ saline/ spring/ chemistry/ guidebookl not algael

Whitehead, H.C. and Feth, J.H. 1961. Recent chemical analyses of waters from several closed-basin lakes and their tributaries in the western United states. Bull. Geol. Soc. Am. 72: $1421-1426$.

This paper is a general review of the chemistry of saline lakes in the West. Chemical characteristics of the lakes are described without specific chemical data.

Whitehead/ California/ Nevada/ Oregon/ Utah/ saline/ lake/ chemistry/ general/ not algael

Willey, L.M., O'Neil, J.R., and Rapp, J.B. 1974. Geochemistry of thermal waters in Long Valley, Mono County, California. U.S. Geol. Surv. Open-File Rept. No.125, Sacramento, Calíf. $19 \mathrm{p}$.

Willey/ California/ chemistry/ thermal habitat/ not algael

Winograd, I.J. and Thordarsen. 1975. Hydrologic and 
hydrochemical framework, south-central Great Basin, Nevada California, with special reference to the Nevada Test site. U.5. Geol. Surv. Prof. Pap. No.712-C. $126 \mathrm{p}$.

This report provides data on ground water in that area.

Winograd/ California/ Nevada/ hydrology/ ground water/ chemistryl not algael 
SECTION 3.0

ALGAL PAPERS: COLORADO

Andrews, K.J., Andrews, B.A., and Anderson, J. 1981 .

Thermophilic micro-organisms found in three Colorado hot springs. Am. Soc. Microbiol. Ann. Meeting Abstracts 1981:

173. (Abstract N3)

Thirty-five organisms were isolated from three Colorado hot springs. Most werebacteria, but some blue-green were isolated. No fungi or eucaryotic algae were cultured.

Andrews/ Coloradol freshwater/ springl blue-green algael thermal habitat/

Cole, G.A. 1963. The American Southwest and Middle America. In Erey, D.G., (ed). Limnology in North American, Chpt.14, p. 393-434. Univ. of Wisc. Press, Madison, Wisconsin.

This is a good general review of all aquatic habitats in the American Southwest and Middie America (Mexico and Central America). Descriptions by area and habitat are provided. The author includes some comparitive chemical data. There are various algae mentioned in the text.

Colel CaIitornial Nevadal Arizona/ Utahl New Mexicol Coloradol Texas/ salinel freshwater/ lakel streaml springl pondl blue-green a Igael green algael diatoml chemistryl generall $r \in v i \in w /$

DureII, L.W. 1959. Algae in Colorado soils. Am. Mid. Nat. 61: $322-328$

This paper lists species occurring in 223 soil samples; 85

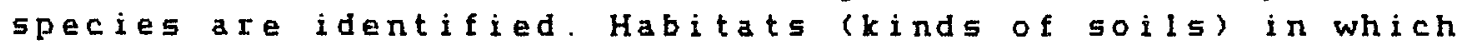
various species occurred are discussed.

Durrell/ Colorado/ soil/green algae/ blue-green algael Euglenophyta/ Chrysophyta/ species Iist/cultures/

Durre11, L.W. 1956. Micro greenhouses. The Green Thumb. July 1956, p.17.

In many places in Colorado flat quartz pebbles lie in profusion on the ground intermixed with other kinds of small rocks. On overturning these stones, the quarta ones are ofter found to 
have algae growing on the under surface, while other pebbles do not. This seems Iogical as the quartz pebbles, though not transparent, appear translucent, and in the micro climate below them there exists a miniature greenhouse - moist and ight and of tairly favorable temperature during much of the year. Such quarta chips have yielded several species of soil algae both of green and blue-green kinds. Like a miniature greenhouse, the quartz pebbles keep the soil under them from drying out, and a 150 permit the transmission of light adequate for growth of the minute green plant life below.

Durreli/ Colorado/ soil/ blue-green algael green algael

Flowers, 5. 1963. Study of non-vascular plants of Dinosaur National Monument. Univ. Utah Miscell. Pap. No.1, p.50-68.

This is a short discussion of algal species occureing in Dinosaur National Monument.

Flowers/ Utah/ Colorado/ freshwater/ river/ springl Chrysophytal green algael Euglenophytal blue-green algael species Iist/ successionl

Hagen, H.K. and Banks, J.E. 1963. An ecological and limnological study of the Green River in Dinosaur National Monument. Rept. to U.S. National Park Service.

Diatoms, blue-green algae, and green algae in the Green River are mentioned.

Hagent Utahl Coloradol freshwater/ riverl blue-green algael di a tom $/$

Kuliberg, R.G. 1977. The effects some ecological factors on cell size of the hot spring alga Synechococcus lividus

(Cyanophyta). J. Phycol. 13:111-115.

The total dissolved substances increases gave longer cells at 70-74.5 degrees centigrade, but not at lower temperatures. This was a field study ot 30 thermal springs.

Kullberg/ Colorado/ Idaho/ Montana/ Wyoming/ freshwater/ springl blue-green algael chemistry/diversity/ thermal habitat/

Morris, M.K., Taylor,W.D., Williams, L.R., Hern, S.C., Lambou, V.W. and Morris, F.A. 1979. Distribution of phytoplankton in 
Colorado lakes. U.S. Environmental Protection Agency, Ecol. Res. Ser. Rept. No. EPA-600/3-79-114.v+40p.

This is a data report presenting the species and abundance of phytoplankton in the 13 lakes sampled by the National

Eutrophication survey in the state of Colorado. Results from the calculation of several water quality indices are also included (Nygard's Trophic State Index, Palmer's Organic Pollution Index, and species diversity and abundance indices).

Morris/ Coloradol treshwater' lake/ blue-green algael green a Igael diatoml dinoflageliate/ Chrysophytal Euglenophytal cryptophyta/ species list/ diversity/

Robbins, W.W. 1912. Preliminary listing of the algae of Colorado. Colo. Univ. Studies, Series A, General studies 9 : $105-118$.

The paper gives the determination of specimens of algae collected in Colorado by the biological staff of the University of Colorado, together with records abstracted from the gereral Iiterature. In all 143 species are listed. Many examined are from Boulder County - some from the city of Boulder. Other collections reported were made largely in the higher altitudes of Gilpin county in the vicinity of Tolland.

Robbins/ Coloradol freshwater/ lakel streaml springl blue-green algae/ green algae/ species list/

Robbins, W.W. 1912. Algae in some Colorado soils. Bull. Colorado Agric. Sta. 184:24-36.

A gae occur abundantly in many cultivated soils of colorado. Twenty-one different species of algae were found in the soils examined. With but two exceptions, all the species found belong to the blue-green algae (Cyanophyceae.) The family Nostocaceae is best represented. There is a predominance of forms possessing thick, gelatinous sheaths.

Robbins/ Coloradol freshwater/ soil/ blue-green algael green algael species list/ cultures/ illustrations/ 
SECTION 3.1

RELATED HABITAT PAPERS: COLORADO

Peale, A.C. 1886 . Lists and analyses of the mineral springs of the United States. BuIl. U.S. Geol. Surv. No.32, Washington, D.C. $235 \mathrm{p}$.

This paper lists the locations and the status of many saline springs in the United states, especially in the West. Nothing on a lgae.

Peale/ Idahol Utah/ Arizona/ New Mexicol Californial Oregonl Montana/ Wyoming/ Nevada/ Colorado/ saline/ spring/chemistry/ general/guidebook/ not algael 
SECTION 4.0

ALGAL PAPERS: NEVADA

Armstrong, W.P. 1982. Dangeardinella: In every drop of brine. Environment Southwest, San Diego Nat. History Museum No.499: $18-20$.

A popular account describing the distribution of this unusual a lga in brine samples from eastern California and Nevada. This alga has affinities with the Prasinophyceae of the chrysophyta. Celis and habitats where they are found are illustrated.

Armstrong/California/ Nevada/ saline/ lake/ pond/greenalgael iIIustrations/

BIinn, D.W. 1971. Autecology of a filamentous alga, Ctenocladus circinnatus (Chlorophyceae) in saline environments. Can. J. Bot. 49:735-743.

Six highly saline habitats in arid regions of British Columbia, Nevada, and California with the chaetophoralean Ctenocladus circinnatus Borzi were investigated to characterize the unique enviconment of this alga. Seasonal patterns within three of these habitats were analyzed to reveal those parameters deterwining the restricted distri bution of Ctenocladus. Sodium was the dominant cation in combination with any major anion, such as sulfate, carbonate and bicarbonate. Seasonal salinity fluctuations of the water solutions were large (〈10-〉100 milimhos). Ctenocladus tolerated these high salinities and temperatures (-3 to 28 C) as akinetes formed early in the summer and they survived 35 akinetes until dilution of the water solutions the next spring. The period for optimum vegetative development was short ( $6 \ldots 12$ weeks) because of an increase in salinity and temperature of the waters. Akinete germination in the lab was optilua between 9 and 26 C and temperatures above 34 C destroyed akinetes. Conversely, the freezing of akinetes produced no adverse affects. Laboratory studies showed germination and vegetative development retarded at pH below 8 . 0 with akinetes destroyed beIow 7.0. Light is essential for germination with low light intensities $(214$ lux) stimulating germination. Light intensities above 12000 lux destroyed akinetes within 5 days. Saxual reproduction in bot the field and laboratory was absent. The significance of the akinete and lack of sexual reproduction are correlated with laboratory and field data and the restricted distribution of Ctenocladus.

BIinn/ British Columbia/California/ Nevada/ saline/lake/ pond/ green algae/ chemistry/ environmental factors/ ecology/ 
Blinn, D.W. and Stein, J.R. 1970. Distribution and taxonomic reappraisal of Ctenocladus (Chlorophyceae: Chaetophorales).

3. Phycol. 6: 101-105.

The distribution of the rare filamentous green alga Ctenocladus Borzi was examined on a world-wide basis. All the collection sites are restricted to specific inland habitats. Most of these locations are in arid regions of North America with a few scattered sites in Peru, Sicily, and Siberia. This alga has been referred to 2 genera, either Ctenocladus or Lochmiopsis

Woronochin \& popova, for the past 45 years. Based on field observations, laboratory cultures, and herbarium material, Lochmiopsis is considered synonymous with Ctenocladus. The response of vegetative cell dimensions to seasonal changes (i.e., osmotic potential and tempersture) in 3 saline habitats in Eritish Columbia was also investigated. Results from the study, long with laboratory dilutions of natural saline waters, showed that cell dimensions are not valid criteria for separating species of ctenocladus as proposed by some authors. Consequentiy Ctemocladus is considered a monotypic genus with physiological variants responding to seasonal enviconmental conditions. (In North America this alga has been collected at Mono Lake and Borax Lake, California; Green Pond and Red Pond, Arizona; $A B \in t$ lake, Oregon and at several locations in British Columbia. Isolates from the latter locations are illustrated).

Hlinn/ British Columbia/ California/ Oregon/Arizona/ Nevada/ 53 linel lake/ pond/ green algael taxonomyl illustrationsl

Brves, C.T. 1928 . Studies on the fauna of hot springs in the western United States and the biology of thermophilous animals. Froc. Am. Acad. Arts Sci. 63: 139-228.

"This paper is a very short discussion of blue-green algae in hot springs. It primarily provides data on invetebrate fauna of hot springs in several states. Locations of each are given.

Brues/California/ Nevada/ New Mexicol Utah/ saline/ freshwater/ spring/ biue-green algael zoologyl

Cameron, R.E. and BIank, G. k. 1966. Desert algae: Soil crusts and diaphnous substrata as algal habitats. Jet Propul. Lab. Tech. Rept. No. 32-971, p1-41.

The most favorabie habitats in desert soils occur in algal and lichen soil crusts, and on the undersurface of transiucent or tranparent materisl partialiy imbedded in the soil surface. Algal abundance is increased and ecological factors are much less restrictive in these ecological niches than in the surcounding dsert soil. Insolation is modified, more moisture 
is retained, dessication is reduced, and organic matter accumulations are noticeatie. Characteristics of transicent materials, such as white or milky quarta and chalcedony, which are partialiy imbedded in the surface of desert soils, permit the existence of mesophilic algal inhabitants, such as species of coccoid and blue-green algae, that do not normaliy occuras components of xeric soil populations. Other species are cosmopolitan forms occurring in a wide range of environments, including habitats at low or high elevations in hot or cold deserts. The probable occurcence of a number of transiucent and transparent minerals in extratercestrial soils and other geological materials may also provide a favorable ecological niche or microenvironment for organisms and associated organic matter in an otherwise harsh macroenvironment.

Cameron/ Arizona/ CaIifornia/ Nevada/freshwater/ saline/ soill diapharous substratal biue-greer algae/green algae/ review/ i l I ustrations!

Carlson, J.S., Everett, L.G. and Qashu, H.K. 1971. Chemical and biological patterns in the lower Colorado River system. Unpub. Rept., Univ, of Arizona. Unpaged.

Results presented in this paper are intended: 1 ) to stimulate interests for discussions of abiotic-biotic interactions in the Colorado River System, 2) to identify some hydro-biological patteins to guide our current research program, and 3 ) to identify appropriate analytic procedures and sampling. Spatial and temporal variabilities in system properties are real and considered in the curcent research program on Lake Mead. These changes are caused by the nature of changes in inputs--water, sediments, solutes, sewage effluent, and other recreational products. Degradation of the phytoplankton and zooplankton were observed and changes in species dominance was illustrated across Lake Mead and in other parts of the Lower Colorado River system. Causes of these changes are speculative at this time and may be associated with changes in concentrations of essential nutrient species. Limiting amounts ot some essential micro-nutrients were documented in axeas showing undesicable changes in plankton species. The increase in many ions may in tact cause the absence of changes in the biota or serve to enhance the limiting effects of low concentrations of micronutrients.

Carlson/ Utah/ Arizona/ Nevada/Californial freshwater/ blue-green algael diatom/ green algael dinoflagellatel zoologyl chemistryl

Cole, G.A. 1963. The American Southwest and Middle America. In Erey, D.G., (ed). Limnology in North American, Chpt.14, P.393-434. Univ. ot Wisc. Press, Madison, Wisconsin.

This is a good general review of all aquatic habitats in the 
American Southwest and Middle America (Mexico and Central America). Descriptions by area and habitat are provided. The author includes some comparitive chemical data. There are various algae mentioned in the text.

Cole/ Californial Nevadal Arizonal Utah/ New Mexicol Coloradol Texas/ salinel freshwater/ lake/ stream/ springl pond/ blue-green algae/ green algael diatom/ chemistry/general/ reviewl

DeGuire, M.F. 1974. A study of the eutrophication of the surface waters of Lake Pyramid. M.S. Thesis, Univ. of Nevada, 45 p.

The blue-green alga, Nodularia spumigena, which forms blooms in Pyramid Lake, Nevada, was culturedat various levels of temperature, I ight intensity, and phosphate using batch cultures. The optimum light intensity was 15 foot-candies and growth was reduced at intensities above this level. Death and cell bleaching occurred at high intensities, in just a few minutes at 1000 foot-candles. The optimum temperature was $22 \mathrm{C}$ and growth was reduced at $21 \mathrm{C}$ and $23 \mathrm{C}$. Phosphate was not Iimiting. Continuous culture experiments showed that growth rates increased with increasing medium flow rate. This suggested that some nutrient other than phosphate was limiting. The results are discussed in relation to bloom formation in the lake.

Deguire/ Nevada/ Pyramid Lake/ saline/ lake/ blue-green algael chemistry/ cultures/ light / temperature/ nutrients/ bloom/

Drouet, E. 1943. Myxophyceae of eastern California and western Nevada. Field Mus. Nat. Hist., Bot. Ser.20: 145-177.

This paper includes a good description of many species of blue-green algae and their locations.

Drouet/ CaIifornia/ Nevada/ freshwater/ saline/ springl stream/ soil/ pool/ lake/ bIue-green algae/ species list/

Durrel1, L.W. and Shields, L.M. 1961. Characteristics of soil algae relating to crust formation. Trans. Am. Microsc. Soc. $80: 73-79$.

This paper describes the binding of soil particles by blue-green algae, particularly Microcoleus vaginatus.

Durrelif New Mexicol Nevadal soil/ blue-green algael cultures/ 
Edmondson, W.T. 1963 . Pacific Coast and Great Basin. In Frey, D.G., (ed). Limnology in North America, Chpt. 13, p.371-392. Univ. ot Wisc. Press, Madison, Wisconsin.

This is a general review of the limnology of this area. Some listings of algae are included.

Edmondson/ California/ Oregon/ Washington/ Nevada/ Utahl salinel freshwater/ lake/ river/pond/chemistry/general/ review/

Emerson, D.N. 1976. Limnological observations on the Humboldt River near Elko, Nevada, June and August, 1974. Am. Zool. 16: 195 .

The author mentions green algae as periphyton and green algae, blue-green a Igae and diatoms as phytoplankton. The rocky bottoms were the most productive while mud and sand were observed to be mostly sterile. There is not too much information in this paper as it is only a meeting abstract.

Emerson/ Nevada/freshwater/ river/green algael blue-green algael diatoml

Everett, L.G. 1972. A mathematical model of primary productivity and limnological patterns in Lake Mead. Repts. Nat.

Resource systems No.13. $151 \mathrm{p}$.

Dominant algae were Asterionelia and Ceratium. The temporal and spatial changes in chemical and biological properties of Lake Mead have been investigated, thereby indicating the sources of water poliution and the time of highest pollution potential. Planktonic organisms have been shown to indicate the presence of water problems. Macro- and micro-nutrient analyses have shown that primary productivity is not inhibited by limiting concentrations. A mathematical model has been developed, tested with one set of independent data, and shown worthy of management utility. Although the model works very well for the Lake Mead area, the physical reality of the Multiple Linear Regression equation should be tested on independent data.

Everett/ Arizona/ Nevada/ freshwater/lake/ diatom/ dinoflagellatel production/ ecology/ chemistry/zoologyl nutrients/

Everett, L.G., Carlson, J.S. and Qashu, H.K. 1971. Chemical and biological patterns in the lower Colorado River system. J. Ariz. Acad. Sci. 8: $91-94$. 
The abundance of diatoms and green algae decreased in a downstream directon from Lake Fowell to Lake Mead to Lake Havasu. These algae were replaced by filamentous blue-green a lgae and dinoflagellates. There is only speculation as to why these changes occur - possibly because of water chemistry changes or changes in grazing pressure.

Everett/ Arizona/ Nevada/ Californial Utah/ freshwater/ river/ diatoml green algael dinoflagellatel blue-green algael zoologyl chemistry/ nutrients $/$

Galat, D.L., Lider, E.L., Vigg, S. and Robertson, S.R. 1981. Limnology of a large, deep, North American terminal lake, Pyramid Lake, Nevada, U.S.A. Hydrobiologia B2: $281-317$.

This paper is a general discussion of the limnology of pyramid Lake. Species I ists of planktonic algae and periphyton are given. Dominant species are the green alga, Nodularia spumigena and the diatom, Chaetoceros elmorei. Primary production measurements were made.

Gajat/ Nevada/ Pyramid Lake/ Saline/ Iakel green algael blue-green algael diatom/ chemistry/ species list/periphyton/

Galat, D.L., McConnell, W.J. and Hamilton-Galat, K. 1977. Organic matter contributions to Pyramid Lake. In Greer, D.C., (ed). Desertic Terminal Lakes. Utah Water Research Lab., Logan, Utah. p. 371-383.

Phytoplankton production, benthic plant production, and river and wind-blown alochthonous organic matter inputs were measured. The lake's annual organic matter budget was estimated at $72,952 \mathrm{~m} . \mathrm{t} C\left(0.789 \mathrm{~g} \mathrm{C} \mathrm{m}^{-2} \mathrm{day}^{-1}\right)$. Phytoplankton contributed $90 \%$, benthic plants less than $1 \%$, river $3 \%$, and wind-blown vegetation about 6.5\%. Much of the phytoplankton production was due to Nodularia and probably enters the consumer trophic levels via detritus. Compared with primary production of other lakes, Pycamid Lake is classed as mesotrophic. Its simplified trophic structure implies efficient energy transfer as the primary mechanism for its apparent high fish production.

Galat/ Nevada/ Pyramid Lake/ saline/ lake/ blue-greenalgael productionl

Hanna, G.D. and Grant, W.M. 1931. Diatoms of Pyramid Lake, Nevada. Trans. Am. Microse. Soc.50:281-297.

Sediment samples were collected and washed to obtain living diatom specimens. These are described and illustrated. 
Hanna/ Nevada/ Pyramid Lake/. saline/ lake/ diatom/ chemistry/ il I ustrationsl

HaIt, J. 1981. Hiking the Great Basin. Sierra CIub Books, San Francisco. $372 \mathrm{p}$.

There is little mention of algae but this book is a good general detailed guide to the Great Basin, including parts of eastern Calitornia, western Utah, southeastern Oregon, and most of Nevada. Some warm and/or saline springs, creeks and lakes where algae should be found are mentioned.

Hart/ CaIifornial Utahl Nevada/ Oregonl freshwaterl salinel spring/ stream/ lake/general/guidebook/ thermal habitat/

Herre, A.W.C.T. 1911. The desert lichens of Reno, Nevada. Bot. Gaz. 51:286-296.

The author describes lichens near Reno and the factors that might aftect them.

Hercel Nevadal soil/ freshwater/ review/ Iichens/ environmental factors/

Heviy, R.H. 1961 . Notes on aquatic non-flowering plants of northern Arizonz and adjoining regions. Plateau 33:88-92.

This paper describes a few algae collected at various sites in northern Arizona, southern Utah, and southern Nevada.

Heviy/ Arizona/ Utah/ Nevada/ freshwater/ stream/ Iake/ pondl green algael blue-green algael

Hutchinson, G. E. 1937. A contribution to the limnology of arid regions. Trans. Conn. Acad. Sci. 33:47-132.

This is a discussion of the general limnology of several desert lakes in Nevada. Some chemical and physical data is included. In some lakes, algae species are listed.

Hutchinson/ Nevada/ saline/ freshwater/ lake/ green algael blue-green algael diatom/ Euglenophyta/ chemistry/ physics/ species I ist/ 
Kennedy, J.L., Lider, E.L. and Robertson, S.R. 1977. Limnology of Pyramid Lake. In Greer, D.C., (ed). Desertic Terminal Lakes. Utah Water Research Lab., Logan, Utah. p.337-354.

Sampling was conducted along three transects. Maximum surface temperatures occurred in July, minimum in January, with thermal stratification present from June to December. Mean total dissolved solids was $5,223 \mathrm{mi} l i$ igrams per 1 iter, dominated by sodium and chloride ions. Five species of cladocerans, two species of copepods, and three genera of rotifers were identified in net samples. Diaptomus sicilis was the dominant species of zooplankton, and Ceriodaphnia quadrangula was second most abundant. Summer phytoplankton were dominated by Chaetoceros, Cyclotelia, and stephanodiscus. The blue-green algae, Nodularia and Ansbaena, were present in much lower numbers. Oligochaetes comprised $64.6 \%$ of the total number of benthic macroinvertebrates collected and were most abundant in the 9 to 23 and 24 to 46 meter depth zones. Chironomids comprised $34 \%$ of the total and were most abundant in the 9 to 23 meter depth zone

Kennedy/ Nevada/ Pyramid Lake/ lake/ saline/ diatom/ blue-green algae/ green algae/ chemistry/ species list/

Koch, D., Hoffman, L., and Mahoney, J. 1976. Fyramid Lake: Zooplankton distributions and blooms of the blue green alga, Nodularia spumigena. Project Rept. No.38, Water Resources Center, Desert Res. Inst., Univ. of Nevada, Reno. $46 \mathrm{p}$.

This paper gives seasonal cycle data on algae and zooplankton in Pyramid Lake, Nevada. A blue-green alga, Nodularia spumigena, forms blooms in late summer but the alga does not affect zooplankton except perhaps by overcrowding. Algal bioassays indicated that $P$ is a limiting nutrient.

Koch/ Nevada/ Pyramid Lake/ Iake/ saline/ blue-green algael chemistry/ bIoom/

Koch, D., Mahoney, J., Spencer, R., Cooper, J. and Jacobson, R. 1977. Limnology of Walker Lake. In Greer, D.C., (ed). Desertic Termina Lakes. Utah Water Research Lab., Logan, Utah.

The Walker Lake research project is reviewed. Chemical studies have shown that the lake is homogeneous in time and space today and that alkalinity and salinity are functions of both modern lake level recessions and re-solution of sediments of the prehistoric Lake Lahontan. Silicate-carbonate relationships are discussed and a nomer of valuable minerals in the lake have created additional interest in chemical equilibria. The phytoplanktor flora is diverse but dominated by centric diatoms 
in winter and the blue-green alga Nodularia in summer.

Zooplankton populations are severly restricted; only three taxa have been observed, and these are abundant only before and after the warmest summer months. Lake stratification and low dissolved oxygen restrict the distulation to the uppter 10 m of waters during this period. Only three fish species are of importance in the lake: Salmo clarki henshawi, Gila bicolor obesus, and Catostomus tahoensis. The tui-chub appear to play an important role in the food web and trophic structure of the lake; food habits, reproduction, and distulation have been intensively studied. Declining Lahontan cutthroat trout populations have caused alarm for the lake's economic importance and bioassay-survival testing of a number of exotic species tor possible planting and of indigenous trout have revealed mechanisms contributing to the habitat degredation.

Koch/ Nevada/ Walker Lake/ lake/ salinel blue-green algael green algael diatom/ chemistry/ ecology'

Koch, D.L., Cooper, J.J., Lider, E.L., Jacobson, R.L. and Spencer, R.J. 1979. Investigations of Walker Lake, Nevada: Dynamic ecological relationships. Univ. of Nevada Desert fles. Inst. Publ. No. 50010 . 191p.

This is a general discussion of ecology of Walker lake. The blue-green alga, Nodularia spumigena was dominant, particularly in summer. Diatoms were more abundant at other times of year (1975-1977). Seasonal chlorophyll levels were alsogiven, as was data on zooplankton and fish. The mean total dissolved solids concentration was $10,650 \mathrm{mg} 1$ iter'

Koch/ Nevadal Walker Lake/ salinel lake/ blue-green algael green algae/ diatom/ chemistry/ ecology/general/ nutrients/

Koenig, E.R., Tew, R.W. and Deacon, J.E. 1972. Phytoplankton successions and lake dynamics in Las Vegas Bay, Lake Mead, Nevada. J. Ariz. Acad. Sci. 7: 109-112.

Phytoplankton species succession from March to May is described. Increases in stephanodiscus in April and in Cyclotelia in May occurred. The latter species was probably resuspended from the bottom. Nutrient-rich Las Vegas Wash water (sewage effluent) forms a density current that interchanges with lake water. There is not much explanation of the reasons for successions.

Koenig/ Nevada/ freshwater/ lake/ diatom/ succession/

La Rivers, I, 1965. A prelininary Iisting of the algae of Nevada. Occas. Pap. Biol. Soc. Nevada, No.6, 15p. 
Two hundred and thirty-eight species are listed. There is very little data on locations.

La Rivers/ Nevada/ freshwater/ saline/ green algael Euglenophyta/ Chrysophytal diatom/ blue-green algael species I ist /

Ia Rivers, I. 1978 . Algae of the Western Great Basin.

Bioresources Center, Desert Research Institute, University of Nevada system, Reno, Nevada. 390 .

This book is a reasonably complete description of all algae occurring in Nevada (particularly the western partof the state) and in eastern California; some algae are recorded from Arizona. The book contains keys and illustrations and discusses the history ot algal research in these areas. The book has a glossary and index. Locations are given for each species. Chlorophyta, Euglenophyta, Chrysophyta. (with diatoms), Cyanophyta, and Rhodophyta are included. This is a definitive work on desert algae.

La Rivers/ Nevada/ California/ Arizonal salinel freshwater/ lake/ soil/pond/stream/ spring/blue-green algaelgreenalgael Euglenophyta/ diatom/ Chrysophyta/ general/ taxonomy/ il lustrations/

Lambou, V.W., Morris, F.A., Morris, M.K., Taylor, W.D.,Willams, L.R. Hern, S.C. 1979. Distribution of phytoplankton in Nevada Iakes. U.S. Environmental Protection Agency, Ecol. fes. Ser. Rept. No. EPA-600/3-79-117. v+34p.

This is a data report presenting the species and abundance of phytoplankton in the 10 lakes sampled by the National

Eutrophication 5 urvey in the 5 tate of Nevada. Results from the calculation of severel water quality indices are also included (Nygaard's Trophic State Index, Palmer's Organic Pollution Index, and species diversity and abundance indices). of special interest are data for Walker Lake and Lake Mead.

Lambou/Nevada/ freshwater/ saline/lake/ blue-green algael green algael diatom/ dinoflageliate/ Euglenophyta/ Chrysophytal Cryptophytal species Iist/diversityl

Milier, R.R., Soltz, D.L. and Sanchez, F.G. 1977. Fishes and Aquatic Resources of the Death Valley System, CaIiforniaNevada, $1878-1976$. A Bibliography. U.S. Dept. Interior, Nat. Park Serv. 27 p. 
This is a general bibliography of biota and water in Death $\mathrm{Va} 11 \mathrm{ey}$.

Millex/California/ Nevada/ saline/ freshwater/bibliography/

Minckley, C.O. and Deacon, J.E. 1975. Foods of the Devil's Hole puptish, Cyprinodon diabolis (Cyprinodontidae). Southwest. Nat. 20: 105-111.

Food habits of the unique Devils Hole pupfish, Cyprinodon diabolis wales were studied from data collected during a 14-month period. A general pattern of opportunism in feeding and responses to variations in food supplies was indicated. Inorganic particulate matter remained highest in volume, frequency of occurcence, and numericaliy throughout the period. The green alga, Spirogyra, and various diatoms were about equal in occurrence, but varied seasonally in a reciprocal manner with diatoms being most important in winter and spring. The amphipod, Hyalelia, was present more frequently than either an unidentified ostracod or protozoans which were found about the same frequency. Other endemic organisms found in small numbers were the elmid beetle, Stenelmis, a turbeliarian, Dugesia, and a hydrobiid snail, Tryonia. Six of the 66 available stomachs were empty.

Minckley/ Nevada/ freshwater/ pool/green algaeldiatom/

Shields, L.M. and Drouet, E. 1962. Distribution of terrestrial algae within the Nevada Test Site. Am. J. Bot. 49:547-554.

Twelve terrestrial algal species, other than diatoms, were identified by microscopic examination of natural soil growths trom the Nevada Test Site. Four soil species appearedir culture onIy. Eifteen tana occurred only in the vicinity of the one aquatic habitat. Colloidal sheaths of Microcoleus vaginatus, Schizothrix californica and schizothrig aculissima stabilize soil particles, forming a surface crust. Nostoc commune, scytonema hofmanni and Protosiphon cinnamomeus are commonly associated with Iichens. With one exception, no natural algal growths were found within 0.6 mile of nuclear detonation points during the 2 years following an event. Since at least one species, Microcoleus vaginatus, survives acute gamma exposures of $2,560 \mathrm{kr}, \mathrm{blast}$ and thermal damage, rather than radiation, appear to account for the removal of soil algae. The slow recovery can be explained largely in terms of aridity. Soil texture, which influences cohesiveness and moisture Ievels, strongly affects the composition of terestrial algal populations in relation to major shrub types within the test site.

Shields/ Nevada/ soil/ bIue-green algae/green algaeldiatoml 
species I ist I

Shields, L.M., Durrell, L.W. and Sparrow, A.H. 1961. Preliminary observations on radiosensitivity of algae and tungi from soils of the Nevada Test Site. Ecology 42:440-441.

Three algal species in soils of the Nevada Test Site (Microcoleus vaginatus, Phormidium tenue and synechococcus cedrorum) survived a maximum of 1,280 kr. total acute gamma cadiation in laboratory exposures at Brookhaven. Eive taxa of fungi developed in culture following total dosages of 640 kr (stemphylium ilicis, Fusarium sp., Phoma sp., Alternaria tenuis and streptomyces sp.).

Shields/ Nevada/ soil/ blue-green algae/cultures/

Staker, R.D., Hoshaw, R.W., and Everett, L.G. 1974. Phytoplankton distribution and water quality indices for Lake Mead (CoIorado River). J. Phycol. 10:323-331.

Phytoplankton samples were collected in Lake Mead 6 times from September 1970 to June 1971 for 8 stations at depths of $0,3,5$, 10,20 , and $30 \mathrm{~m}$. These 5 amples were processed through a Milipore filter apparatus and 79 planktonic algae were identified. Algal divisions represented were Bacillariophyta, 42 spp.; ChIorophyta, 18 ; Cyanophyta, 9; Chrysophyta， 3 ; Cryptophyta，3; Pyrrophyta, 2; and Euglenophyta, 2. BIue-green algae were dominant in late summer and fall; green algae, diatoms, and crytomonads in winter; and green algae in spring. The early summer flora was best represented by the chlorophyta, Cryptophyta, and Chrysophyta. Palmer's pollution-tolerant algae indices and Nygard's indices were calculated from phytoplakton data. These indices suggest eutrophic conditions in Lake Mead, especially for Boulder Basin.

Staker/ Arizonal Nevada/ freshwater/ lakel blue-green algael green algae/ diatom/ Chrysophyta/ Cryptophyta/ Euglenophyta/ dinoflagellatel maps/

Stark, N. 1969. Microecosystems in Lehman Cave, Nevada. Bull. Nat. Speleol. Soc. 31:73-82.

This paper describes 12 ecosystems occurring in a cave with food web diagrams. These are in lighted areas and in dark areas. Sixteer algal species are listed.

Stark/ Nevadal freshwaterl cavel blue-green algael green algael diatom/ ecology/ species list/ 
Van Landingham, S.L. 1966. Diatoms from dry lakes in Nye and Esmeralda Counties, Nevada, U.S.A. Nova Hedwigia 11 : $221-241$.

Three samples from dry lakes (playas) in Nye and Esmeralda Counties, Nevada, U.S.A. Yielded 61 taxa of diatoms. The diatom group is similar to that which one finds in soils. These dry lake diatoms are believed to be soil diatoms or at least related to soil diatom groups (populations). Most of these diatoms were similar to those in arid conditions. The study of the diatom and a lgal. flora of this unusual type of lake has been neglected and should be much more explored, especially in view of the tact that these dry lakes are abundant and widespread over the world.

Van Landingham/ Nevada/ salinel playa/lake/ soil/diatom/ taxonomy/ species Iistl

Woods, H.C. 1871. AIgae. In Watson, S., (ed). U.S. Geol. Explor. 40 th Farallel 5 (Botany): 415 .

Occurrences of snow algae in the Clover and East Humboldt mountains of Nevada are reported.

Woods/ Nevada/ freshwater/ snowfields/ green algael 
Anderson, E.R. and Pritchard, D.W. 1951. Final Report: Physical I imnology of Lake Mead. U.S. Nav. Electronics Lab. Rept. No. $258.153 \mathrm{p}$.

This report describes the physical limnology of Lake Mead from cruises taken in 1948-1949. Nothing on algae.

Anderson/ Nevada/ Arizonal freshwater/ lakel physics/ not algael

Arler, R.P., Gersberg, R.M. and Paulson, L.J. 1978. Primary productivity in meromictic Big Soda Lake, Nevada. Great Basin Nat. $38: 187-192$.

In situ radiocarbon uptake measurements conducted at Big soda Lake, Nevada, indicate that (i) bacterial photosynthesis comprises an important fraction $(30 \%)$ of the lake's total primary production and ( $i$ ) bacterial chemosynthesis contributes significantly to organic particle production. The results of nutrient encichment bioassay experiments support Hutchinson's prediction that availability of inorganic nitrogen, rather than phosphorus, limits primary production in the mixolimnion. Nutrient additions of nitrate-N with Fe+3 most stimulated carbon-14 uptake.

Axler/ Nevada/ saline/ lake/ chemistry/ nutrients/ not algael

Brues, C.T. 1932. Eurther studies on the fauna of North American hot springs. Am. Acad. Arts and Sci.67: 186-303.

There is no information given on algae, but there are good descriptions of numerous hot springs in the west.

Brues/ Nevada/ CaIifornia/Utah/ saline/freshwater/springl zoology/ thermal habitat/ not algael

Kimme1, B.L., Gersberg, R.M., Paulsen, L.J., Axler, R.F., Goldman, C.R. 1978 . Recent changes in the meromictic status of Big Soda Lake, Nevada. Limnol. Oceanogr. 23: 1021-1025.

Big Soda Lake has shifted from a partially closed to an open meromictic system, probably due to a progressive depression of the chemocitine to a level below that of sub-surface inflow. The stability increase initially accompanying that shift has been 
followed by a gradual decrease in stability. The observed mean annual work done and chemocline descent rate indicate that meromixis in Big Soda Lake is unlikely to persist for longer than another few decades. Nothing on algae.

Kimmel/ Nevada/ saline/ lake/ chemistry/ not algael

Koenig, E.R., Baker, J.R., Baulson, L.J. and Tew, R.W. 1971 . Limnological status of Big Soda Lake, Nevada, October, 1970. Great Basin Nat. 31: 106-108.

On 17 October, 1970, the thermociline in the mixolimnion of Big Soda Lake, Nev., was located between 15 and 20 m below the surface. The chemoci ine was found to lie between 30 and $35 \mathrm{~m}$ depth. Significant dilution of the lake has occurced since 23 JuI y 1933 .

Koenig/ Nevada/ salinel Iake/ chemistry/ not algael

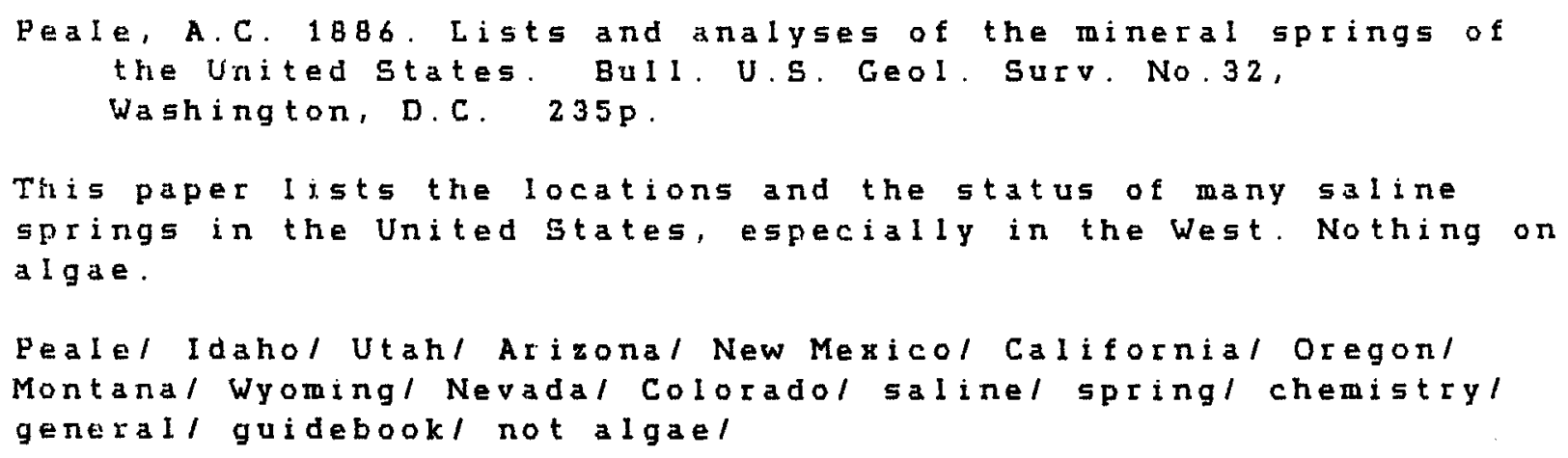

Russel1, I.C. 1895. Present and extinct lakes of Nevada. Nat.

Geogr. Mono. 4: 1-132.

This paper is a general, early description of Nevada lakes. Some early chemical analyses of water of various lakes is presented.

Russeli/ Nevada/ saline/ freshwater/ chemistry/ geology/ general/ not algael

Russe11, I.C. 1885 . Geological history of Lake Lahontan, a quaternary lake of northwestern Nevada. U.S. Geol. Surv. Mono, Vol. 11 . $288 \mathrm{p}$.

Some early chemical data on remnat lakes are presented. This is a very pleasing old book. 
Russeli/ Nevada/ lake/ geology/ chemistry/ illustrations/ not a Igael

Shep, L. 1972. The effects of photoperiod and some environmental factors on plant growth in Lehman Cave, Nevada. Bull. Natl. Speleol. Soc. 34:15-25.

This is an interesting paper on cave ecology.

Shep/ Nevada/freshwater/ cave/ environmental factors/ ecology/ not a lgael

Wheeler, S.S. 1968. The Desert Lake. The Story of Nevada's Pyramid Lake. Caxton Printer, Caldwell, Idaho. 133p.

This is a general layman's description of Pyramid lake with little scientific data. Many pictures of big trout that have been caught in the lake are included.

Wheeler/ Nevada/ Pyramid Lake/ saline/ lake/ zoology/ history/ general' illustrations/ maps/ not algael

Whitehead, H.C. and Feth, J.H. 1961. Recent chemical analyses of waters from several closed-basin lakes and their tributaries in the western United States. Bull. Geol. Soc. Am. 72: $1421-1426$.

This paper is a general review of the chemistry of saline lakes in the West. Chemical characteristics of the lakes are described without specific chemical data.

Whitehead/ California/ Nevada/ Oregon/ Utah/ saline/ lake/ chemistryl generall not algael

Winograd, I.J. and Thordarsen. 1975. Hydrologic and hydrochemical framework, south-central Great Basin, Nevada California, with special reference to the Nevada Test Site. U.S. Geol. Surv. Prof. Pap. No.712-C. $126 \mathrm{p}$.

This report provides data on ground water in that area.

Wirograd/ California/ Nevada/ hydrology/ ground water/ chemistry' not algael 
SECTION 5.0

ALGAL PAPERS: NEW MEXICO

Bradbury, J.P. 1967. Origin, Paleolimnology, and limnology of Zuni Salt Lake maar, west-central New Merico. Ph.D. Thesis, Univ, of N.M. 247p. Univ. Microfilms, Inc., Ann Arbor, Mich. No.68-3456.

The kinds and numbers of algae in zuni $5 a 1 t$ lake and the nearby Cinder Cone Pond vary with salinity. Yellowish green algae blooms occur atter summer rains. There is little diversity only four genera of blue-greer and green algae are listed in the lake, but diatoms as well as these occur in the pond. The chemistry is similar to that of seawater or Great salt Lake in that sodium and chloride are principal ions. Brine shrimp are the dominant zooplanktor. The food chain is simple and similar to that of Mono Lake, California. Numerous species of diatoms are listed for sediments.

Bradbury/ New Mexicol salinel lakel pondl blue-green algael green algael diatom/ physics/ chemistry/geology/ zoology/maps/ blooml

Bradbury, J.P. 1971. Limnology of Zuni Salt Lake, New Mexico. Geol. Soc. Arner. BuIl. 82: 379-398.

This is a good general review of limnology - physical, chemical and biological - and geology of zuni salt Lake and the cinder Cone Pool. A chemical composition table is given and the water is compared with seawater and that of Great SaIt Lake. The algae vary with salinity changes. Algal species are listed in the $t \in x t$.

Bradbury/ New Mexicol salinel lakel blue-green algael diatoml green algael chemistryl

Brues, C.T. 1928. Studies on the fauna of hot springs in the western United States and the biology of thermophilous animals. Proc. Am. Acad. Arts Sci. 63: 139-228.

This paper is a very short discussion of blue-green algae in hot springs. It primarily provides data on invetebrate fauna of hot springs in several states. Locations of each are given.

Brues/ Californial Nevada/ New Mexicol Utahl salinel freshwaterl spring/ blue-green aIgae/ zoology/ 
Cameron; R.E. 1969. Abundance of microflora in soils of desert regions. Tech. Rept. 32-1378, Jet Propul. Lab., Pasadena, CaIifornia. $16 \mathrm{p}$.

Surface soils were collected by aseptic techniques from cold, polar, hot volcanic, and high mountain deserts, and were analyzed for physical, chemical, and microbiological properties. Soils showed a wide range of properties but were generally greyish, yellowish, or brownish sands, low in organic matter and cation exchange capacity. There were detectable concentrations of water-soluble ions, and pH values above 7.0 , except in volcanic areas. Total microbial abundances ranged from zero (undetectable) to $>10^{9} \mathrm{gm}^{-1}$ of soil. Aerobic and microaerophilic bacteria were most abundant, followed by algae and molds. The anaerobic bacteria were generally least abundant or undetectable. Fredominant microflora included Bacilius spp., 5oil diptheroids, Schizothrix spp. and other oscillatrioid blue-green a lgae, Streptomyces spp., Peniciliium spp., and Aspergilius spp.

Cameron/ Californial Oregon/ Arizonal New Mexicol soill bIue-green algael green a lgael

CoIe, G.A. 1963. The American Southwest and Middle America. In Frey, D.G., (ed). Limnology in North American, Chpt.14, p.393-434. Univ. of Wisc. Press, Madison, Wisconsin.

This is a good general review of all aquatic habitats in the American Southwest and Middle America (Megico and Central America). Descriptions by area and habitat are provided. The author includes some comparitive chemical data. There are various algae mentioned in the teat.

Colel California/ Nevada/ Arizona/ Utah/ New Mexicol Coloradol Texas/ salinel treshwater/ lakel stream/ springl pond/ blue-green algael green algael diatoml chemistrylgenerall $r \in v i$ ew/

Durtell, L.W. and Shields, L.M. 1961. Characteristics of soil algae relating to crust formation. Trans. Am. Microsc. Soc. $80: 73-79$.

This paper describes the binding of soil particles by blue-green algae, particularly Microcoleus vaginatus.

Durrel1/ New Mexico/ Nevada/ soil/blue-greenalgaelcultures/

Hoham, R.W. and Blinn, D.W. 1979. Distribution of cryophilic algae in an arid region, the American southwest. Phycologia 


\section{8: 133-145.}

In the American southwest, species distribution was related mostly to exposure. Chloromonas nivalis was the dominant species found in thicty-one of thirty-four collecting areas containing snow algae. It caused green to orange colouration of snow in mostly shaded regions of the forests. Cryocystis granulosa celi type was most prevalent in the southwestern portion of the study area. It caused orange to orange-red colouration of snow near tree canopies and usualy received more irradiation than populations of ChIoromonas nivalis. Carteria nivale - Scotiella polyptera cell types dominated in each of the six collecting areas where they were found in shaded regions in the eastern portion of the study. These cell types caused green colouration, usualiy in horizontal bands up to 25 cm below the surface in residual snowbanks. Chlamydomonas nivalis prevailed above timberline at the northern region of the study. This species caused red snow and dominated in the open exposures. Chromulina chionophilia and a colourless euglenoid flageliate were found at scattered localities in the southwest. Chromulina was found in open exposures and near tree canopies. The colourless euglenoid was found only in the shaded snowbanks near trees, and this is the first report of a colourless alga from snow. In the American southwest, orange and green snow were the dominant types.

Hoham/ Acizonal New Mexicol Utahl freshwaterl snoweields/ green algael Chrysophyta/ Euglenophyta/ species Iist/ i I I strationsl

Lambou, V.W., Morris, F.A., Morris, M.K., Taylor, W.D., Williams, L.R. and Hern, S.C. 1979. Distribution of phytoplankton in New Mexico lakes. U.S. Environmental Protection Agency, Ecol. Res. Ser. Rept. No. EPA-600l $3-79-118 . v+30 p$.

This is a data report presenting the species and abundance of phytoplankton in the 8 lakes 5 ampled by the National Eutrophication Survey in the 5 tate of New Mexico. Results from the calculation of several water quality indices are also included (Nygard's Trophic state Index, Palmer's Organic Pollution Index, and species diversity and abundance indicess.

Lamboul New Mexicol freshwaterl salinel lakel green algael blue-green algae/ diatom/ dinoflageliate/ Euglenophyta/ Chrysophyta/ Cryptophyta/ species list/diversity/

Shields, L.M. 1957. Algal and lichen floras in relation to nitrogen content of certain volcanic and arid range soils. Ecology $38: 661-663$.

This paper is a short discussion of algae and Iichens a 
contritutors to the nitrogen content of desert soils.

Shields/ New Mexicol soill blue-green algael green algael chemistry/ species list/ cultures/ lichens/

Shields, L.M., Mitche11, C. and Drouet, F. 1957. AIga- and lichen-stabilized surface crusts as soil nitroger sources. Am. J. Bot. 44: $489-498$.

This paper describes algal and lichen crusts as sources of nitrogen in desert soils via $N$ fination.

Shields/ New Mexicol soil/ blue-green algael greenalgael chemistry/ Iichens/ nitrogen fixationl 
SECTION 5.1

RELATED HABITAT RAPERS: NEW MEXICO

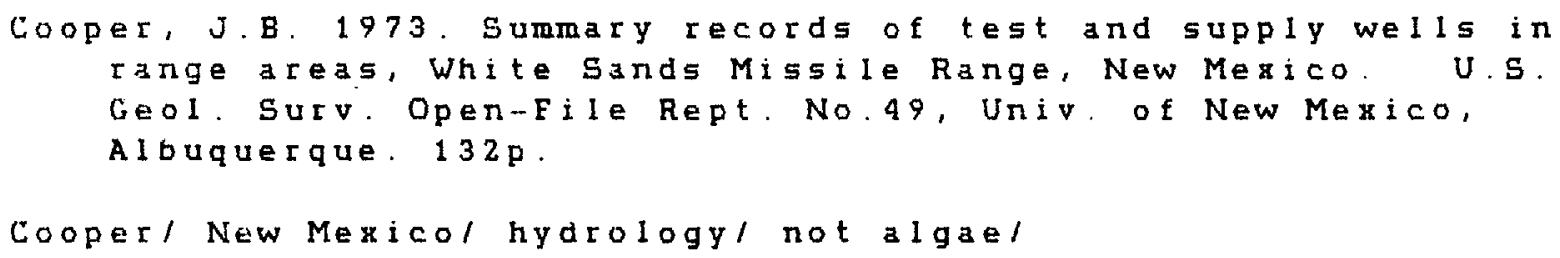

El1is, M.M. 1940. Water conditions affecting aquatic Iife in Elephant Butte Reservoir. Fish. Bull., U.S. Bur. Eisheries No. $44: 257-303$.

The general 1 imnology of Elephant Butte Reservoir in $1935-8$ is described. There is some discussion of fish, but nothing on a 1 gae.

Ellis/ New Mexico/freshwater/ lake/ physics/ chemistry/ not algael

Hood, J.W. and Kister, L.R. 1962. Saline-water resources of New Mexico. U.5. Geol. Surv. Water-Supply Pap. No.1601.80p. B maps.

This paper gives chemical data and locations of rany saline water supplies in New Mexico and relates aquifers to geological formations.

Hood/ New Mexicol salinel wells/ springl river/ streaml lakel chemistry/ geology/ hydrology/ maps/ not algael

New Mexico Geological Society. 1950 - 1975. Field Conference Guidebooks, Nos.1-26, New Mexico Bureau of Mines and Mineral Resources, Socorio, NM 87801 .

This series has a number of review papers on water supplies and 
geology of New Mexico. There is nothing on algae, but provides useful related information.

New Mexicol salinel freshwater/ river/ stream/ lakel geologyl hydrology/ not algael

Peale, A.C. 1886 . Lists and analyses of the mineral springs of the United States. Bull. U.S. Geol. Surv. No.32, Washington, D.C. 235 .

This paper lists the locations and the status of many saline springs in the United states, especially in the West. Nothing on a Igae.

Pealef Idahol Utah/ Arizona/ New Mexicol Californial Oregonl Montana/ Wyoming/ Nevada/ Colorado/ salinel spring/chemistry/ general/guidebook/ not algael 
SECTION 6.0

ALGAL PAPERS: OREGON

Blinn, D.W. and stein, J.R. 1970. Distribution and taxonomic reappraisal of Ctenocladus (Chlorophyceae: Chatophorales).

J. Phycol. 6: 101-105.

The distribution of the rare filamentous green alga ctenocladus borzi was examined on a world-wide basis. All the collection sites are restricted to specific inland habitats. Most of these locations are in arid regions of North America with a few scattered sites in Peru, sicily, and siberia. This alga has been referred to 2 genera, either ctenocladus or Lochmiopsis Woronochin Popova, for the past 45 years. Based on $f$ id observations, laboratory cultures, and herbarium material, Lochmiopsis is considered synonymous with Ctenocladus. The response of vegetative cell dimensions to seasonal changes (i.e., osmotic potential and temperature) in 3 saline habitats in British Columbia was also investigated. Results from the study, along with laboratory dilutions of natural saline waters, showed that cell dimensions are not valid criteria for separating species of Ctenocladus as proposed by some authors. Consequently ctenocladus is considered a monotypic genus with physiological variants responding to seasonal environmental conditions. (In North America this alga has been collected at Mono Lake and Borax Lake, California; Green Pond and Red Pond, Arizona; Abert Lake, Oregon and at several locations in British Columbia. Isolates from the latter locations are iliustated).

Blinn/ British Columbia/ California/Oregon/Arizona/ Nevada/ salinel lake/ pond/ green algael taxonomyl illustations/

Cameron, R.E. 1969 . Abundance of microflora in soils of desert regions. Tech. Rept. 32-1378, Jet Propul. Lab., Pasadena, california. $16 \mathrm{p}$.

Surface soils were collected by aseptic techniques from cold, polar, hot volcanic, and high mountain deserts, and were analyzed for physical, chemical, and microbiological properties. Soils showed a wide range of properties but were generally greyish, yeliowish, or brownish sands, low in organic matter and cation exchange capacity. There were detectable concentrations of water-soluble ions, and pH values above 7.0 , except in volcanic areas. Total microbial abundances ranged from zero (undetectable) to>10 $0^{9} \mathrm{gm}^{-1}$ of soil. Aerobic and microaerophilic bacteria were most abundant, followed by algae and molds. The anaerobic bacteria were generally least abundant or undetectable. Predominant microflora included Bacilius spp., soil diptheroids, schizothrix spp. and other osciliatrioid blue-green algae, Streptomyces spp., penicillium spp., and Aspergillus spp. 
Cameronl California/ Oregon/ Arizona/ New Mexicol soill blue-green algael green algael

Castenholz, R. W. 1969. Thermophilic blue-green algae and the thermal environment. Bact. Rev. 33:476-504.

This paper is a general review of blue-green algae in hot springs and their ecology, physiology, and culture. The author had mainly studied hot springs in eastern Oregon.

Castenholz/ Oregon/ salinel spring/ blue-green algael ecologyl review/ species list/ cultures/ light/ temperaturel thermal habitat/

Edmondson, W.T. 1963. Pacific Coast and Great Basin. In Erey, D.G., (ed). Limnology, in North America, Chpt. 13, p.371-392. Univ. of Wisc. Press, Madison, Wisconsin.

This is a general review of the Iimnology of this area. Some I istings of algae are included.

Edmondson/ Californial Oregon/ Washington/ Nevadal Utahl salinel freshwater l lake/ river/ pond/ chemistry/ general/ review/

Hart, J. 1981. Hiking the Great Basin. Sierra Club Books, San Francisco. 372 p

There is little mention of algae but this book is a good general detailed guide to the Great Basin, including parts of eastern California, western Utah, southeastern Oregon, and most of Nevada. Some warm and/or saline springs, creeks and lakes where a Igae should be found are mentioned.

Hart/ California/ Utah/ Nevada/Oregon/freshwater/ salinel spring/ stream/ lake/ general/guidebook/ thermal habitat/

Kemmerer, G., Bovard, J.F., and Boorman, W.R. 1923. Northwestern lakes of the United States: Biological and chemical studies with reference to possibilities in production of fish. Eish. Buli., U.S. Nat. Mar. Fish. Serv. 39: 51-140.

This is mostly a discussion of tish and invertebrates. There are some algal counts. The lakes are not realiy in the desert.

Kemmerer/ Oregon/ Washington/ Idahol Californial freshwater/ lake/ blue-green algael green algael diatoml chemistryl 
Phillips, K.N. and Van Denburgh, A.s. 1971. Hydrology and geochemistry of Abert, Summer, and Goose Lakes, and other closed-basin lakes in south-central Oregon. U.S. Geol. Surv. Prof. Pap. No.502-B. 86p. 2 plates.

This paper describes the hydrology and chemistry of several desert lakes in Oregon and northeastern Californi. There is some mention of algae in Lake Abert.

Phillips/ Oregonl Californial saline/ freshwater/ lakel blue-green algael green algael diatoml chemistryl nutrientsl

Williams, J.E. and Williams, C.D. 1980. Feeding ecology of Gila boraxobius (Osteichthyes: Cyprinidae) endemic to a thermal lake in southeastern Oregon. Great Basin Nat. 40: 101-113. The authors identified a few diatoms in fish intestines. Williams/ Oregonl salinel lakel diatoml ecologyl zoology thermal habitatl 


\section{RELATED HABITAT PAPERS: OREGON}

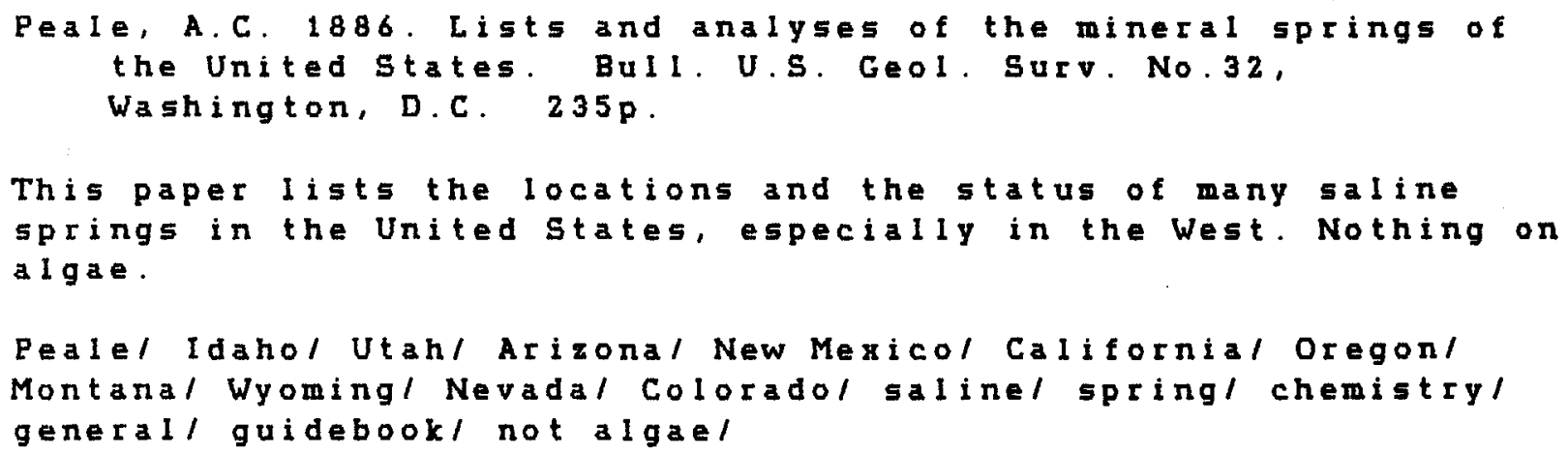

Peale/ Idahol Utah/ Arizona/ New Mexicol California/Oregon/ Montana/ Wyomingl Nevada/ Coloradol salinel springl chemistryl general/ guidebook/ not algael

Van Denburgh, A.S. 1975. Solute balance at Abert and Summer Lakes, south-central oregon. U.S. Geol. Surv. Prof. Pap. No. $502-C$. $29 p$.

This is a discussion of chemistry of these two lakes with emphasis on a solute budget.

Van Denburgh/ Oregon/ saline/ lake/ chemistry/ not algael

Whitehead, H.C. and Eeth, J.H. 1961. Recent chemical analyses of waters from several closed-basin lakes and their tributaries in the western United states. Bull. Geol. Soc. Am. 72: 1421-1426.

This paper is a general review of the chemistry of saline lakes in the West. Chemical characteristics of the lakes are described without specific chemical data.

Whitehead/ California/ Nevada/ Oregon/ Utah/ saline/ lake/ chemistry/ general/ not algael 
SECTION 7.0

ALGAL PAPERS: TEXAS

Bane, C. and Lind, O.T. 1978. The beuthic invertebrate standing crop and diversity of a small desert stream in the Big Bend National Park, Texas. Southwest Nat. 23: 215-226.

This paper is mostly about invertebrates, but algal mats of the gateen algae, Spirogyra and Cladophora, are mentioned.

Banel Texasl freshwater/ 5 treaml green algael

Browri, Jr., H.M., Larson, D.A. and Bold, H.C. 1964. Airborne algae: Their abundance and heterogeneity. Science 143: $583-585$.

Petri plates with "Bold's Basal Medium" were erposed to air at groundlevel via moving automobile and from a plane. The algal content of dust can be extremely high csome counts 300 algae meter ${ }^{-3}$ ). The algal population in blowing dust frequently exceeds that of fungi which formerly have been classified as primary agents tor dust allergies. Algae are present at all times except after washout by rain, and so forth. The algal content of air frequently exceeds that of pollen, particularly during seasons when the production is low. Algal diversity does not a lways accompany an increase in quantity and seasonal periodicity in quantity or diversity, has not, as yet, been demonstrated to exist in the Austin area.

Brown/Texas/ freshwater/air/green algael Chrysophytal blue-green a Igael diversityl

Cole, G.A. 1963. The American Southwest and Middle America. In Erey, D.G., (ed). Limrology in North American, Chpt.14, p. 393-434. Univ. of Wisc. Press, Madison, Wisconsin.

This is a good general review of all aquatic habitats in the American Southwest and Middle America (Mexico and Central America). Descriptions by area and habitat are provided. The author includes some comparitive chemical data. There are various algae mentioned in the text.

Cole/ Californial Nevada/ Arizona/ Utah/ New Mexicol Coloradol Texas/ salinel freshwater/ lake/ stream/ spring/ pond/ biue-green algae/ greenalgae/ diatom/ chemistry/generall review/ 
Cooper, W.A. and Newton, C.A. 1975. Phytoplankton succession in a maturing northwest Texas reservoir (Lake Meredith). Tex.

J. Sci. $26: 449-458$.

A temporal succession of phytoplankton was observed over a year and a half in Lake Meredith, an impoundment in the Texas Panhandle. This succession consisted of an apparently organism-produced phosphorus depletion. Following depletion, the phosphorus remained at near constant concentration which was more limiting for the green alga Ankistrodesmus falcatus than was nitroger for the diatom Cyclotelia meneghiniana. Thus, Ankistrodesmus was reduced as an important member of the communty. Fol lowing the reduction of Ankistrodesmus, 2 colonial a lgae, Coelastrum microporum and oocystis borgei, began to "shift" within the community structure to fill the niche(s). A change in the structure of "blooms" before and after the Cyclotelia "blooms" became smaller and blended with the diatom to form a symetrically cumulative "bloom".

Cooper/ Texas/freshwater/ lake/ green algael diatom/ blue-green algael dinoflageliate/ Euglenophytal chemistry/ species list/ successionl nutrients/bloom/

Deason, T.R. and Bold, H.C. 1960. Phycological studies. I. Exploratory studies of Texas soil algae. Univ. Texas Publ. No.6022. $72 \mathrm{p}$.

A I ga were cultured from soil of the Carrizo sands, CaIdwell County and from Williamson County, Texas. Twenty organisms were found. These were green algae and xanthophyceae. Cytology of each and life cycles are discussed. The algae are tigured by drawings and photomicrographs.

Dezson/Texas/ soil/ green algae/Chrysophyta/ species list/ taxonomy/ iliustrations/cultures/

Pettitt, J.M. and Dutton, R.H. 1977. Limnological theses and dissertations concerning Texas waters, 1897 - 1976 . Tex. J. Sci. $28: 295-338$.

Seven hundred seventy-seven titles of limnologically oriented theses and dissertations were collected over a five-year period by the author. Universities and colleges in Texas and bordering states were surveyed by various methods. The titles are indexed according to key words in the respective titles. Although the major period of time is from 1897 through 1975 , there is a 1976 addendum which includes those listings currently in progress.

Pettitt/ Texas/ freshwater/ salinel soil/ stream/ riverl lakel oceanl blue-green algael green algael zoologyl chemistryl 
bibliography/ production/ diversity/ nitrogen fixation/ thermal habitat $/$ review

Proctor, V.W. 1959. Dispersal of fresh-water algaeby migratory water birds. Science 130:623-624.

Many migratory water birds killed in Texas and oklahoma contained viable fresh-water algae in the lower digestive tracts. Such birds are thought to play a significant role in the long-range dispersal of certain algae, particularly those species easily killed by dessication.

Proctorl Texas/ Oklahomal freshwaterl playal pond/ diatoml green a Igael cuituresl 


\section{SECTION 7.1 \\ RELATED HABITAT PAPERS: TEXAS}

Meigs, C.C., Bassett, H.P. and Slaughter, B.G. 1922. Report on Tezas alkali lakes. Bull. Univ. of Texas No.2234.

There is nothing on algae in this paper, but some Texasalkali lakes are described.

Meigs/ Texas/ salinel lakel chemistryl not algael 


\section{SECTION B. 0}

ALGAL PAPERS: UTAH

Anderson, D.C. and Rushforth, S.R. 1977. The cryptogam flora of desert soil crusts in southern Utah, U.S.A. Nova Hedwigia 28: $691-727$.

Fifty-eight algae were identified from soil samples. Algal crusts check erosion of desert soils. Qualitative abundances of each species are listed in tabular form along with location found.

Anderson/ Utah/ saline/ freshwater/ soil/ blue-green algae/ green algael Euglenophyta/ Chrysophyta/diatom/ species Iist/ iII ustrationsl

Benson, C.E. and Rushforth, S.R. 1975. The algal flora of Huntington Canyon, Utah, U.S.A. Bibl. Phycol.. J. Cramer, Vaduz. $177 \mathrm{p}$.

One hundred and ninety-six species are listed for this freshwater stream. These are discussed in terms of location along the stream and in ponds at the base of the mountains. Species are also discussed in relation to their seasonal occurrence.

Benson/ Utah/ freshwaterl stream/ pond/ diatom/ blue-green algae/ green algae/ Euglenophyta/ dinoflagellatel Chrysophyta/ species list/ illustrations/ taxonomy/ succession/

Bolke, E.L. 1979. Dissolved-oxygen depletion and other effects of storing water in Elaming Gorge Reservoir, Wyoming and Utah. U.S. Geol. Surv. Water-Supply Pap. No.2058. 41 p.

In this paper, dissolved oxygen changes are discussed. An algal. species occurring in a bloom in 1975 is mentioned.

Bolke/ Wyomingl Utahl freshwater/ lake/ blue-green algael green algael diatom/ chemistry/ species list/ bloom/

Brock, T.D. 1975. Salinity and the ecology of Dunaliella from Great Salt Lake. J. Gen. Microbiol. 89: 285-292.

Dunaliella is found at salinities ranging from $10 \%$ (w/v) to $>30 \%$. In enrichment culture from the Great salt lake, at lower salinities a wide variety of algae (species not stated) grew, 
but at higher salinities only Dunalielíla was obtained. Optimum salinities for growth and photosynthesis of Dunaliella were 10-15\% and these parameters were decreased at higher salinities. Thus Dunaliella, while being the only alga able to withstand high salinities is not necessarily growing at its optimum salinity in nature in the Great salt lake.

Brock/ Utah/ Great salt Lake/ saline/ lake/ green algael biue-green algael ecology/ Dunaliellal

Brock, T.D. 1976. Halophilic-Blue-green algae. Arch. Microbiol. $107: 109-111$.

The isolation of a halophilic blue-green alga, Aphanothece halophytica, from Great salt Lake is described. The organism was cultured from waters with salinities up to saturated sodium chloride (about $30 \%$ w/v). It has an optimum salinity for growth of about $16 \%$ sodium chloride, but can grow very slowly even in saturated sodium chloride. Based on the study of the Great salt Lake organism, and on a review of the earlier literature, it is concluded that despite recent reports to the contrary, true halophilic blue-green algae do exist.

Brock/ Utah/ Great Salt Lake/ salinel lake/ blue-greenalgael cultures!

Brues, C.T. 1928. Studies on the fauna of hot springs in the western United states and the biology of thermophilous animals. Proc. Am. Acad. Arts Sci. 63: 139-228.

This paper is a very short discussion of blue-green algae in hot springs. It primarily provides data on invetebrate fauna of hot springs in several states. Locations of each are given.

Brues/ California/ Nevada/ New Mexicol Utah/ salinel freshwaterl spring' blue-green algael zoologyl

CarIson, J.S., Everett, L.G. and Qashu, H.K. 1971. Chemical and biological patterns in the lower colorado River system. Unpub. Rept. Univ. of Arizona. Unpaged.

Results presented in this paper are intended: 1) to stimulate interests for discussions of abiotic-biotic interactions in the Colorado River System, 2) to identify some hydro-biological patterns to guide our current research program, and 3 ) to identify appropriate analytic procedures and sampling. Spatial and temporal variabilities in system properties are real and considered in the current research program on Lake Mead. These changes are caused by the nature of changes in inputs--water, sediments, solutes, sewage effluent, and other recreational 
products. Degradation of the phytoplankton and zooplankton were observed and changes in species dominance was illustrated across Lake Mead and in other parts of the Lower Colorado River system. Causes of these changes are speculative at this time and may be associated with changes in concentrations of essential nutrient species. Limiting amounts of some essential micro-nutrients were documented in areas showing undesirable changes in plankton species. The increase in many ions may in fact cause the absence of changes in the biota or serve to enhance the limiting effects of low concentrations of micronutrients.

Carlson/ Utah/ Arizona/ Nevada/Californial freshwater/ blue-green algael diatom/ green algael dinoflagellatel zoologyl chemistryl

Carozzi, A.V. 1962. Observations on algal biostromes in the Great Salt Lake, Utah. J. Geol. 70:246-252.

The detailed investigation of a typical biostrome of the blue-green colonial alga Aphanothece packardii along the shore of the Great salt lake, Promontory Point, Utah, has shown a distinct morphological zonation of the algal growth. The latter consists of four zones from the lake to the land: subparallel festooned ridges; tonguelike festooned ridges; composite rings and flat-topped mounds; $5 \mathrm{mal} 1$ isolated mounds. Detailed cross sections through the biostrome have shown that the morphological zones merely reproduce and frequently exaggerate an underlying topography eroded in firm argiliaceous and oolitic sands. The conclusion reached is that these colonial algae have no characteristic growth pattern of their own but have developed on several types of positive areas separating a system of erosional channels trending at right angles to the shore line.

Carozzi/Utah/ Great Salt Lake/ salinel lake/ blue-green algael

Carter, C.K., (ed). 1971. Some ecological considerations of the Farmington Bay Estuary and adjacent Great Salt Lake state Park. Univ. of Utah, Salt Lake City, Utah. Sections A H.

This is a massive report on this estuary and park including geology, chemistry, bacteriology, protozoa and algae plus terrestrial and sociological studies.

Carter/Utah/ Great Salt Lake/ saline/ lake/ generall

Chantanachat, 5. and Bold, H.C. 1963. Phycological studies II. Some algae from arid soils. University of Texas, Austin. $75 \mathrm{p}$. 
Species trom soil samples were cultured. Growth on various media is discussed. This paper also describes some new species and their cytology and taxonomy.

Chantanachat/ Arizona/ Utah/ freshwater/ soil/ greenalgael blue-green algaeldiatom/ species list/cultures/ taxonomyl il I ustrations/

Christensen, E.M. 1956. Bibliography of Utah aquatic biology. Proc. Utah Acad. Sci. Arts and Lett. 33: $91-100$.

This paper provides a comprehensive bibliography or Utah aquatic biology up to 1956

Christensen/ Utah/ freshwater/ salinel bibliography/general/

CIark, W.J. 1958 . The phytoplankton of the Logan River, Utah, a mountain stream. Ph.D. Thesis, Utah St. Univ. 95 .

This is a comprehensive thesis on phytoplankton of the logan River. Several stations were sampled from November 1955 to June 1957 every few weeks. No pronounced seasonal changes in the canyon section of the river occurred, but there were summer pulses at valley stations. The seasonal increased water flow did not decrease algal density. Increased nutrients increased a lgal densities, but turbidity was without effect. The dominant species are discussed individually.

Clark/Utah/ freshwater/ stream/diatom/blue-green algael green algael dinoflageliatel Chrysophytal Xanthophytal physics/ chenistryl

Clezve, M.L., Porcella, D.B. and Adans, V.D. 1977. Effects of i.ncreased common 5 at ions on the productivity of phytoplankton indigenous to the Colorado River system. J. Phycol. $13($ suppl): 13 .

Batch bottle bioassays were utilized to screen the effects of various salts on the growth of an indigenous diatom and blue-green alga to test for growth inhibition. The selected cations and anions were added in combination to the algae and the growth monitored via fluorescence and optical density. Differing cations produced marked differences in productivity, while the anions effected growth to a lesser extent.

Cleave/ Utah/saline/freshwater/ river/diatom/ blue-green algael 
Cleave, M.L., Porcella, D.B. and Adams, V.D. 1981 . The application of batch bioassay techniques to the study of 5 Iinity toxicity to freshwater phytoplankton. Water Res. $15: 573-584$.

The tefect of salinity additions on the growth of freshwater a Igae was studied in the laboratory utilizing batch biozssays. These batch bioassays were used to screen variations of ten salts in single addition and the concentration effects of the salts on the productivity of standard test alga and an indigenous diatom from lake Fowell. The indigenous algal genus was found to be more tolerant to salinity addition than the standard test alga. The batch bottle biosssays were conducted following the standard algal assay procedure as closely as possible. Variations in the 5 tandard algal assay procedure included media variation with the use of the indigenous alga for test iroculum in the bioassay procedure.

Cleave/ Utah/ freshwater/ salinel lake/ green algael diatom/ cuItures/

Cole, G.A. 1963. The American Southwest and Middle America. In Erey, D.G., (ed). Limology in North American, Chpt.14, p. 393-434. Univ. of Wisc. Press, Madison, Wisconsin.

This is a good general review of all aquatic habitats in the Anerican Southwest and Middle Anerica (Mexico and Central America). Descriptions by area and habitat are provided. The author includes some comparitive chemical data. There are various algae mertioned in the text.

Cole/ California/ Nevada/ Arizona/ Utah/ New Mexicol Coloradol Texas/ salinel freshwater/ lake/ stream/ springl pond/ blue-green algael greenalgael diatom/ chemistry/generall $r$ vi ew $/$

Colitis, N.C. 1977. Ecological studies of terminal lakes - their relevance to problems in limnology and population biology. In Greer, D.C., (ed). Desertic Terminal Lakes, Utah Water Research Lah., Logan, Utah. p411-420.

There is not much on algatin this paper - Artemia is mentioned more often - however there is some data on the relative depth distributions of both. The author reports that $95 \%$ of the algae were small flagellates.

Collins/ Utah/ Great Salt Lake/ saline/ Iake/ greenalgael f I ageliates! 
Coombs, R.E. 1964 . A tloristic and ecological survey of the algal flora of the western Uinta Mountains and adjacent areas. M.A. Thesis, Univ. of Utah. $78 \mathrm{p}$.

This paper lists the species found in a number of habitats. Only occurrence data is reported without quantitative numbers.

Coombs/ Utahl freshwater/ laxe/ river/ stream/ pond/ diatom/ blue-green algael Chrysophytal green algael species list/

Cottam, W.P. 1942. The flora of Great Salt Lake. News Bull. Mineralogical Soc. Utah $3: 35-55$.

This paper reviews an earlier work, namely that of Kirkparick. A species list is given, but not much other data.

Cottaml Utan/ Great $5 a 1 t$ Lake/ salinel lakel blue-green algael greer algael species 1 ist/

Czarrecki, D.B. and BIinn, D.W. 1977. Diatoms of lower Lake Powel I and vicinity. Biblio. Phycol. 28: 1-119.

Describes diatoms from take Poweli with species lists, keys, and i I I ustrations.

Caariecki/ Arizona/ Utah/freshwater/lake/diatom/ taxonomy/ species list/ illustrations/

Daines, L.L. 1917 . On the flora of Great Salt Lake. Am. Nat. $51: 499-506$.

Variations in density of the water of Great salt Lake cause no corresponding variations in the size of Chlamydomonas sp. cells. The indication is that water somewhat less dense than that normally present in the lake, at its present level, is most favorable to the development of Chlamydomonas $5 p$. The diatoms present in the lake multiply best in water much less dense than the dense water at Saltair. At least four species of algae are to be found in the part of the lake investigated and at least five varieties - possibly species - of bacteria have adapted themselves to the severe conditions in the lake.

Daines/ Utah/ Great SaIt Lake/ salinel Iake/ green algael blue-green a Igael diatom/ chemistryl

Edmondson, W.T. 1963. Pacific Coast and Great Basin. In Erey, 
D.G., (ed). Limnology in North America, Chpt. 13, p.371-392.

Univ. of Wisc. Press, Madison, Wisconsin.

This is a general review of the limnology of this area. Some Iistings of algae ate included.

Edmondson/ California/ Oregon/ Washington/ Nevada/ Utah/ saline/ freshwater/ Iake/ river/ pond/ chemistry/ general/ review/

Evenson, W.E., Rushforth, S.R. , Brotherson, J. and Fungladda, N. 1981 . The effects of selected physical and chemical factors on attached diatoms in the Uintah Basin of Utah, U.S.A. Hydrobiologia $83: 325-330$.

Relationships of diatom species to selected physical and chemical parameters in streams are described.

Evenson/ Utah/ freshwater/ stream/ diatom/ chemistryl periphytonl

Everett, L.C., Carlson, J.S. and Qashu, H.K. 1971. Chemical and biological patterns in the lower Colorado River system. J. Ariz. Acad. Sci. B: $91-94$.

The abundance of diatoms and green algae decreased in a downstream directon from Lake Powel I to Lake Mead to Lake Havasu. These algae were replaced by filamentous blue-green algae and dinoflagellates. There is only speculation as to why these changes occur - possibly because of water chemistry changes or changes in grazing pressure.

Everett/ Arizona/ Nevada/ California/ Utah/ freshwater/ river/ diatom/green algae/ dinoflagellate/ blue-green algae/ zoology/ chemistryl nutrients/

Farnsworth, R.B. and Martin, T.L. 1948. The presence and some activities of algae in some western soils. Proc. Utah Acad. Sci. Arts and Lett. 26: 148 .

This is an abstract reviewing the importance of soil algae and giving some numbers per gram of soil.

Farnsworth/ Utah/ Arizonal freshwater/ soil/ blue-green algae/ green algae/ culturesl

Felix, E.A. and Rushforth, S.R. 1980. Biology of the South Arm of the Great Salt Lake, Utah. In Gwynn, J.W. (ed.). Great 
Salt Lake, a Scientific, Historical, and Economic Overview.

Utah Geological and Mineral Survey Bul1. No.116. p305-312.

This paper discusses changes in algal populations due to decreasing 5 alinity - diatoms took over fromblue-greens. Species are listed.

Felial Utahl Great SaIt Lakel salinel Iake/ green algael blue-green algael dinoflageliatel diatom/ species list/ iI I ustrations/

Eelix, E.A. and Rushforth, S.R. 1979 . The algal flora of the Gieat Salt Lake, Utah, U.S.A. Nova Hedwigia 31: 163-195.

A taxonomic study of the algal flora of the creat Salt Lake of Utah, U.S.A., was conducted from November 1975 to July 1978 . The tlora consisted of four blue-green algae, seven green algae, one dinoflageliate and seventeen diatoms.

Eelix/ Utah/ Creat Salt Lake/ saline/ lake/ blue-green algael green a lgael diatom/ dinoflageliatel species list/ i I lustrations/

Eelix, E.A. and Rushforth, S.R. 1977. The algal flora of Great Salt Lake, Utah: A preliminary report. In Greer, D.C., (ed). Desertic Terminal Lakes. Utah Water Research Lab., Logan, Utah. P. $385-392$

A study of the Great Salt Lake, Utah has been performed to determine the algal flora in the lake and to determine what changes in the flora of the lake have occurred since the construction of the southern Pacific Railroad causeway. Results indicate that the flora of the northern arm consists essentially ot two green algal species: Dunaliella salina and Dunaliella. viridis. The southern section presentiy supports a more diverse ilgal flora than at any time in the lake's recorded history. Also, species previously reported as very abundant in the lake, (i.e. Coccochloris elebans) have not been observed in nearly as great a concentration. SGamples were taken with a net and several diatoms were found. The paper mentions flagellates but does not report on them).

Eelix/ Utahl Great Salt Lakel salinel lakel green algael bIue-green algael diatom/ species listl illustrationsl

Flowers, S. 1934 . Vegetation of the Great salt Lake region. Bot. Gaz. 95: 353-418.

Great Salt Lake had its origin in a large Pleistocene Iake named 
Lake Bonnevilie. It covered an area of 19,750 square miles and at its highest level stood about 100 feet above the present level of Great Salt Lake. It was partially drained by erosion of the outlet and then by evaporation and seepage. The climate shows an annual precipitation of about 6-7 inches in the western part of the region and about 16-17 inches in the esstern portion. Evaporation amounts to about 68.67 inches a year, with an average wind movement of 69,139 miles yearly. The growing season free from frost averages approximately 160 days and the annual average temperature is about 50 F. The lake water proper harbors six species of algae, four Myxophyceae and two Chlorophyceae. Aphanothece utahensis and Microcystis packardi are the commonest species and are directly concerned with the formation of a tufa-like deposit with later forms a hardpan. ChIamydomonas sp. is abundant also. At present, Great salt Lake is about 75 miles long and 38 miles wide, with an averge depth of 15 feet, the deepest point being about 40 feet. The brine consists principally of sodium chloride with smaller amounts of potassium, magnesium, and calcium salts. The percentage varies with the fluctuation of lake level, showing approximately $1 \%$ for every toot increase or decrease. At its highest level it showed $13.8 \%$ and at its lowest Ievel $27.72 \%$.

Elowers/Utah/ Great 5 alt Lake/ saline/lake/ soil/ springl blue-green algae/ green algael chemistryl

Elowers, S. 1942 . Plant I ife of the Great $5 a 1 t$ Lake region. New Bul1. Mireralogical Soc. Utah. 3: 36-56.

Algae found in the lake - blue-greens and Chlamydomonas -.. are mentioned. There is a 150 some mention of diatoms in sediments, though this paper is mostly about higher plant commuities.

Elowers/Utah/ Great Salt Lake/ saline/ lakel green algael blue-green algaeldiatom/ species Iist/

Elowers, 5. 1959. Algaecollected in Glen Canyon. Appendix D. In Woodbury, A.M., (ed). Ecological studies of the flora and Eana in GIen Canyon. Anthropological Papers, GIen Canyon Ser. No.7, Dept. of Anthropology, Univ. of Utah. p.203-205.

This paper lists species and locations within Glen Canyon where they were found.

Flowers/Utah/ Arizona/ freshwater/ river/ green algael blue-green algael diatom/ species list/ 
Flowers, S. 1963. Study of non-vascular plants Dinosaur National Monument. Univ. Utah Miscell. Pap. No.1, p.50-68.

This is a short discussion of algal species occurring in Dinosaur National Monument.

Elowers/Utah/ Colorado/ freshwater/ river/ spring/Chrysophyta/ green algael Euglenophytal blue-green algael species list successionl

Elower5, S. and F.R. Evans. 1966. The flora and fauna of the Great salt Lake region, Utah. In Boyko, H. (ed). Salinity and Aridity. New Approaches to Old Problems, W. Junk Publ., The Hague. p367-393.

The few species that have been found in the lake are mentioned. The authors note that the green algae Chlamydomonas in later papers called Dunalielia) thrives at $13-15 \%$ salt and also note that coccochloris forms large (1 cm) colonies.

Elowers/Utah/ Great Salt Lake/ salinel lake/ playal blue-green algael green algael chemistry/geology/mapsl iI lustrations/

Gillespie, D.M. and Stephens, D.W. 1977 . Some aspects of plankton dynamics in the Great Salt Lake, Utah. In Greer, D.C., (ed). Desertic Terminal Lakes, Water Research Lab., Logan, Utah. p. 401-409.

Plankton of the south basin ot the Great salt Lake were sampled over three years, and data on principal zooplankton (Artemia salina) and phytoplankton (Dunalielia) populations are presented. Zooplankton production, estimated using an instantaneous growth method, ranged from $191 \mathrm{gm} \mathrm{m}^{-2}$ year in 1971 to $108 \mathrm{gm} \mathrm{m} \mathrm{m}^{-c^{\prime}}$ yea $\mathrm{r}^{-1}$ in 1973 . Phytoplankton production for 1973 was $2229 \mathrm{C} \mathrm{m}^{-2}$ year! These results show the lake to be very productive, with production of the Artemia among the highest ever estimated for a natural zooplankton population. A speculative scenario is presented suggesting changes in plankton community structure if salinity continues to decrease in the south basin.

Gillespie/ Utah/ Great salt Lake/ salinel lake/green algael diatom/ blue-green algael productionl

Gillespie, D.M., Wirick, C.D. and Stephens, D.W. 1971 . The Great Salt Lake: PIankton ecology in a rigorous environment.

Bu1I. Ecol. Soc. Am. 52: 31 . 
The saline waters of the Great Salt Lake provide an extremely rigorous, and therefore relatively simple ecosystem. The impact ot man on the system has caused rapid physicochemical and ecological changes. Northern and southern basins are physically separated by a railroad causeway, and are ecologically distinct. The northern basin contains saturated brine with a depauperate biota consisting of Dunalielia salina plus some protoroa and bacteria. In the southern basin two major energy flow sequences dominate the system: A planktonic sequence consisting of (Dunaliella) -...-- $\rightarrow$ (AItenia): and a benthic sequence consisting of (blue-green a lgae+detritus)...---- (Ephydra). There is some crossover in that much of the detritus consists of dead Artemia, and Artemia will teed on benthic algae and detritus when Dunalielia are scarce. A preliminary model of the planktonic sequence is presented, with temperature appearing as the principal physical factor. Population dynaics and productivity data are presented in support.

Gillespiel Utah/ Great salt Lake/ salinel lakel blue-green algael green algael ecologyl

Hagen, H.K. and Banks, J.E. 1963. An ecological and limnological study ot the Green River in Dinosaur National Monument. Rept. to U.S. National Park Service.

Diatoms, blue-green algae, and green algae in the Green River are mentioned.

Hagen/ Utah/ Colorado/ freshwater/ river/ blue-green algael di a toml

Haraing, W.J. 1970. A preliminary report on the algal species presently found in Utah Lake. Great Basin Nat. 30:99-105.

Algal species found in this lake located near Provo, Utah are listed. This is a freshwater lake. Twenty-six species are described and il lustrated.

Hardingl Utah/ Utah Lake/ freshwaterl lakel green algael blue-green algae/ Chrysophyta/dinoflageliate/ species list/ il I ustrationsl

Harding, W.J. 1971. The algae of Utah Lake. Part II. Great Basin Nat. 31: 125-134.

Twenty-five additional species not listed in the author's previous paper (Harding, 1970) are reported for a freshwater lake near Provo, Utah. These species are described and i 11 ustrated. 
Harding/Utah/ Utah Lake/ treshwater/ lake/ green algael blue-green a Igael Euglenophyta/ Chrysophytal

Hart, J. 1981. Hiking the Great Basin. Sierra Club Books, San Francisco. $372 \mathrm{p}$.

There is little mention of algae but this book is a good general detailed guide to the Great Basin, including parts of eastern California, western Utah, southeastern Oregon, and most of Nevada. Some warm and/or saline springs, creeks and lakes where algae should be tound are mentioned.

Hart/ CaIifornia/Utah/ Nevada/Oregonl freshwaterl salinel spring/ stream/ lake/general/guidebook/ thermal habitat/

Hayes, C.R. 1971. Distribution, populations, and species diversity of phytoplankton of Earmington Bay. In Carter, C.K., (ed). Some ecological considerations of the Farmington Bay Estuary and adjacent Great Salt Lake State Park. Univ. of Utah, Salt Lake City, Utah. P.E-1 - E-21.

Phytoplankton diversity in relation to salinity is discussed. Generaliy, the greater the salinity, the lower is the diversity. The dominant blue-green alga Nodularia was inhibited by increased salinity.

Hayes/ Utah/ Great Salt Lake/ salinel lakel blue-green algael green algael zoologyl species Iist/

HevIy, R.H. 1961. Notes on aquatic non-flowering plants of northerm Arizona and adjoining regions. Plateau 33:88-92.

This paper describes a few algae collected at various sites in northern Arizona, southern Utah, and southern Nevada.

Hevly/ Arizona/ Utah/ Nevada/ freshwater/ stream/ lake/ pondl green algael blue-green algael

Hoham, R.W. and BIinn, D.W. 1979. Distribution of cryophilic a lgae in an arid region, the American southwest. Phycologia $18: 133-145$.

In the American southwest, species distribution was related mostly to exposure. Chloromonas nivalis was the dominant species found in thirty-one of thirty-four collecting areas containing snow algae. It caused green to orange colouration of snow in 
mostly shaded regions of the torests. Cryocystis granulosa cell type was most prevalent in the southwestern portion of the study area. It caused orange to orange-red colouration of snow near tree canopies and usualiy received more irradiation than populations of Chloromonas nivalis. Carteria nivale - Scotielia polyptera cell types dominated in each of the siu coliecting areas where they were found in shaded regions in the eastern portion of the study. These cell types caused green colouration, usually in horizontal bands up to 25 can below the surface in residual snowbanks. Chlamydomonas nivalis. prevailed above timberline at the northern region of the study. This species caused red snow and dominated in the open exposures. Chromulina chionophilia and a colourless euglenoid flagellate were found at scattered localities in the southwest. Chromulina was found in open exposures and near tree canopies. The colouriess euglenoid was found only in the shaded snowbanks near trees, and this is the first report of a colourless alga from srow. In the American southwest, orange and green snow were the dominant types.

Hoham/ Arizona/ New Mexicol Utah/freshwater/ snowfields/ green algae/ Chrysophyta/ Euglenophyta/ species Iist/ i l lustrations!

Lawson, L.L. and Rushforth, S.R. 1975. The diatom flora of the Provo River, Utah, U.S.A. Bibl. Phycol. 17: 1-149.

One hundred fify-siz diatom species from Provo River are described. The authors divide species into those occurring in the upper river and lower river plus a transition zone in between. Several theses on algae in Utah are cited. All the species are illustrated with cytological descriptions of each species provided. Collection locations are also noted.

Lawson/ Utah/ freshwater/ river/diatom/ species list/ taxonomy/ il I vstrationsl

Leslie, T.A., St. Clair, L. and Whiting, M. 1974. The diatom flora of Utah Lake. Proc. Utah Acad. Sci. 51: 74-75.

One hundred fifty-five species were identified. The conclusion was reached that the lake is not heavily polluted.

Leslie/ Utah/ Utah Lake/ freshwater/ lakel diatom/ diversityl

Langley, Jr., G. 1969. Plankton associations in Antelope Flat area, Flaming Gorge Reservoir. Fh.D. Thesis, Univ. of Utah. $56 \mathrm{p}$.

Plankton associations of a portion of Elaming Gorge Reservoir 
were illustrated using principal components analysis plots. The associations for the entire year were studied, with samples taken weekly in the summer and less often in the winter. The associations of 34 different plankton forms were given for each sampling date. Some of the associations were pointed out for the major forms of zooplankton. An example is the close association of Daphnia pulex with the phytoplankter, Dinobryon sertularia.

Asplanchna and Folyarthra appear to be very active feeders, that are in competition with the crustaceans for many of the same phytoplankton forms. It is possible that they also prey on the naplii and smalles stages of the crustaceans. In the last part of the summer Ceratium hirundinelia is the dominant phytoplankter. It is followed by Eragilaria crotonensis in the fall, Stephanodiscus hantzschi in the winter, Diatoma anceps in the spxing and Dinobryon sertularia in the early partof summer. Asterionelia formosa is the second most abundant form from fall to Iate spring. Associations change faster and the crustaceans are more numerous in summer. Associations appear to be more stable and better defined during the colder parts of the year.

LangIey/ Utah/ freshwater/ I ake/ bI ue-green a Igael dinofiagellatel green algael diatoml Chrysophytal chemistryl zoologyl species Iistl

Loope, W.L. and Gifford, G.F. 1972. Influence of a soil microfioral crust on select properties of soils under pinyon - juniper in southeastern Utah. J. Soil Water Conserv. 27: $164-167$.

Cryptogamic soil crusts on the Colorado plateau were studied to determine their effect on infiltration rates, potential sediment production, permeability, and several chemical properties of the soil. Siz different crust stages were identified. Undisturbed soil cores were used to determine intrinsic permeability under three treatments and distrubed soil samples were analyzed for pH, percent organic matter, soil texture, calciumplus magnesium content, and total conductivity. Cryptogamic crust had little effect on soil chemical properties. Analysis of undisturbed soil core data indicated that high cryptogamic cover tended to reduce intrinsic permeability, an effect that was reinforced when cores were irrigated. Sites with any degree of cryptogamic cover had significantly higher infiltration rates than chained areas (no lichen cover). Patterns of sediment production revealed a potential for increased sediment once the crust had been disturbed.

Loope/ Utah/ freshwater/ soil/ lichens/ physics/

Martin, T.L. 1939 . The occurrence of algae in some virgin Utah soils. Soil sci. Soc. Am. Proc. 4: 249-250. 
Numbers of algae in soils from Utah county were measured. The paper lists the genera found but no conclusions are reached.

Martinl Utahl soil/ green algael diatom/ blue-green algael species Iistl

Martin, T.L. and Snow, E. 1938. Seasonal variation in soil algae in some virgin Utah soils. Proc. Utah Acad. Sci. Arts and Let $t$. $15: 5$.

This is a general abstract on soil algae and their activities.

Martin/Utah/ soill

McCoard, D.L. and Christensen, E.M. 1968. An ecological study of the a I gae and mosses of Cascade Springs, Wasatch County, Utah. Proc. Utah Acad. Sci. Arts and Lett. 45: 316-317.

This paper provides a short discussion of algae in Cascade springs and a species list.

McCoard/ Utah/ freshwater/ spring/ blue-green algael diatom/ green algael species I istl

MeDonald, D.B. and Gaufin, A.R. 1965. The effects of pollution upon Great Salt Lake. Proc. Utah Acad. Sci. Arts and Lett. $42: 191-195$.

Great salt Lake is the larges saline lake in America. The variety and concentration of organisms is generally greatest in those area of the lake where the salt concentration is reduced by inflowing springs and streams. An exception to this rule occurs at the southeastern end of Great salt Lake, where the addition of polluted waters from the salt lake City sewer has resulted in an area of very low productivity in which the organisms found in the lake are inhibited by the pollutants while the saline waters prevent the development of those forms normaliy found in the sewage outtall. Also: Chlamydomonas cultures had a higher growth rate in $60 \%$ lake water than in $100 \%$ lake water.

McDonaldl Utahl Great Salt Lakel salinel lakel green algael blue-green algael environmental factorsl

Mou-sheng, C. and Rushforth, S.R. 1977. The algal flora of the campus of Brigham Young University, Provo, Utah. Great Basin Nat. 37: 402-406. 
The authors lists 160 species of green algae, Euglenophyta, diatoms, Chrysophyta, and blue-green algae. Locations on campus where these species are found are listed.

Moumshengl Utahl freshwaterldiatom/ green algael Euglenophytal blue-green algael Chrysophytal species listl

Nash, T.H., III and Sigal, L.L. 1981. Freliminary study of the lichens of Zion National Park, Utah. J. Ariz. - Nev. Acad. sci. 16: $46-50$.

On the basis of collections made in the suthern two-thirds of Zion National Park, Utah, 159 species of lichenized fungi in 53 genera are reported for the park. Of these 159 species, 4 are new reports for the state of Utah. The richness of the lichen vegetation is enhanced by the favorable moisture conditions of the canyon. The potential for air pollution injury to the lichen vegetation is high because a new coal-tired power genrating plant is proposed $30 \mathrm{~km}$ downstream from the canyon.

Nash/Utah/treshwater/soil/blue-green algael Iichens/ nitrogen fixationl

Nelson, D., Suekawa, D.M. and Havertz, D.S. 1974. Trophic reIationship of brine fly and algae of the Great Salt Lake, Utah. Proc. Utah Acad. Sci. Arts and Lett. 51: 50-55.

This paper describes the food habits of brine fly in Great salt Lake. They eat algae and detritus from sediments.

Nelson/ Utah/ Great SaIt Lakel salinel lakeldiatoml green algael

Packard, A.5., Jr. 1879. The sea-weeds of Salt Lake. Am. Nat. $13: 701-703$

This is a very early description of algae from Great salt Lake and is mostly of historical interest.

Packard/ Utahl Great Salt Lakel salinel lakel grean algael blue-green algael

Peterson, H.B and Martin, T.L. 1937. Algae and azotobacter characteristics of soils at the base of the Wasatch Mountains in Utah Valley. Proc. Utah Acad. Sci. Arts and Lett. 14:29. 
This is a general abstract describing algae found in the soils of the foothilis of the Wasatch Mountains.

Peterson/ Utah/ soil/ diatom/ blue-green algae/green algael species I ist/cultures!

Porcella, D.B. and Holman, J.A. 1972. Nutrients, algal growth, and culture of brine shrimp in the southern Great $5 a 1 t$ Lake. In Riley, J.P., (ed). The Great Salt Lake and Utah's Water Resources. Utah Water Research Lab., Utah State Univ. and Utah Div. Water Resources, Utah State Univ., Logan, Utah. p 1 42-155.

The overall objective of this study was to measure nutrients in Great Salt Lake waters and to determine how the alga, Dunalielia sp. responds to nutrients. The relationship between tood supply (algae) and the growth and reproduction of brine shrimp Artemia sp. Was also studied. Based on chemical analyses inorganic nitrogen is apparently the limiting factor for growth in the samples of Great Salt Lake water. Carbon may also be limiting. Phosphorus, iron and other trace elements seem to be in abundant supply. These observations were confirmed by algal bioassays. Brine shrimp were fed on several concentrations of Dunalielia as well as on yeast celis. Growth and reproduction of the brine shrimp on the algae alone was superior to yeast alone. The optimum utilization by the brine shrimp ws about 1,000 algal cells per brine shrimp per day. Different concentrations and ages of added algae had no apparent effect on whether the mature brine shrimp produced live young (nauplii) or resistant cysts. It can be concluded that a feasible aquaculture based on Dunaliella and Artemia can be developed for brine shrimp isolated from the Great salt Lake. Production of algae and brine shrimp in lake enclosures may be increased by addition of specitic nutrients.

Porcella/ Utahl Great Salt Lake/ salinel lakel green algael chemistry/ zoology/ nutrients!

Post, E.J.1980. Oxygen-rich gas domes of microbiol origin in the salt crust of the Great Salt Lake, Utah. Geomicrobiol. Jour. $2: 127-139$.

In 1977, a severe drought throughout the western part of the United 5 tates caused the north arm of the Great SaIt Lake, Utah, to evaporate to its lowest level in a number of years, resulting in the precipitation of about $99.6 \%$ pure sodium chloride. At the extreme north end of the north arm, in the vicinity of Monument Point, Iow humidity combined with a shallow-bottom gradient to form a sat crust along the lake margin in which gas-emitting domes were common. The domes varied in size; each contained a 
large amount of gas showed to be 82 to $86 \%$ oxygen and 14 to $18 \%$ Iitrogen, with<0.2\% or no methane, and no detectable carbon diogide. The bottom of the crust domes ( 3 to $4 \mathrm{~cm}$ thick) was a bright red color. Microscopic examination of this revealed $3.5 \times 10^{+}$cells of Dunalielia salina, $2 \times 10^{3}$ cells of D. visidis and $10^{8}$ to $10^{7}$ cells of red halophilic bacteria per g of salt. Measurements in situ showed sufficient Iight ( $34 \mathrm{kIx}$ ) and temperature ( 34 C) under the salt to favor the growth of algae and associated bacteria within the water phase of the crust or in water immediately underneath the crust. Oxygen produced as a result of algal photosynthesis was trapped under the crust until the crust either was eroded by waves or broken under pressure. The domes were not observed during the summers of 1978 and 1979.

Post/Utah/ Great Salt Lakel salinel lakel green algael chemistigl

Post, E.J. 1980. Biology of the North Arm. In Gwynn, J.W. (ed). Great Salt Lake, a Scientific, Historical, and Economic Overview. Utah Geological and Mineral survey Bull. No.116. p313-321.

The extreme stress of high salt, about $360 \mathrm{~g} \mathrm{I}^{-1}$, and low oxygen solubility in the north arm of the Great salt Lake has led to a biological community of low diversity and few species. Those organisms with adaptive mechanisms evolved to withstand the rigors of this harsh environment occur in numbers large enough to color the water a wine red. Nutrients seem abundantly available except for an inorganic source of nitrogen. The bacteria supply what little ammonia is available for the algae and the algae in turn excrete organic matter used by the bacteria. Organic nitrogen is plentiful but possibly in a form unavailable to the bacteria since it does not seem to support their growth. Each of the biological members, bacteria, bacteriophage, algae, brine fly and brine shrimp is discussed, as well as the community as a whole.

Post/ Utah/ Great Salt Lake/ salinel lake/ green algael chemistry/ nutrients/

Post, E.J. Life in the Great Salt Lake. Utah Sci. 36:43-47.

This is a popular discussion of the biota of the Great salt Lake and their relationships. Very little specific data on the algae are given.

Post/ Utah/ Great SaIt Lake/ salinel lakel green algael chemistry/general/ 


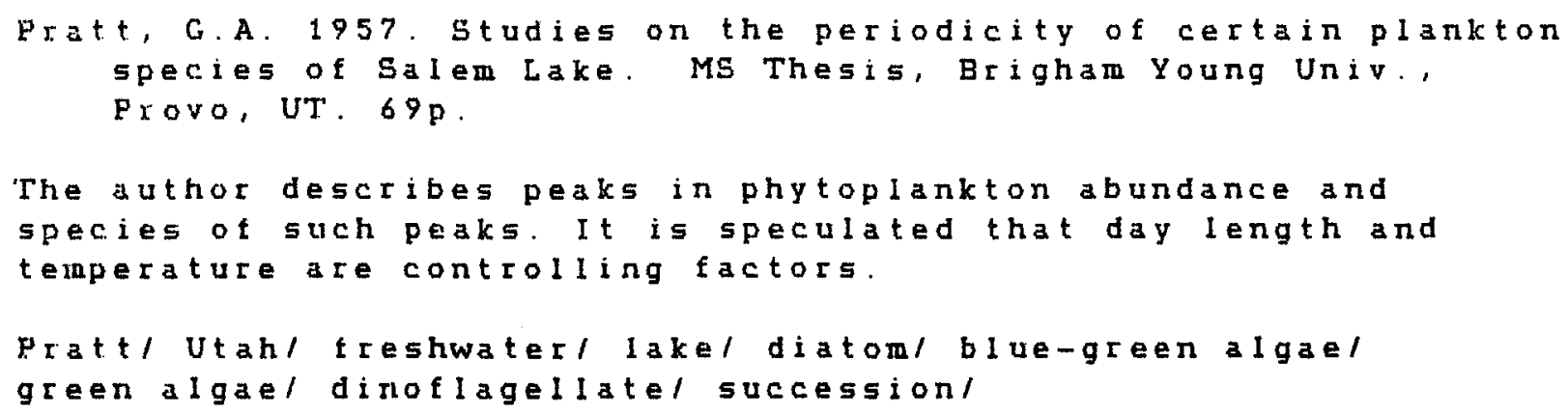

Riley, J.P. 1972. The Great Salt Lake and Utah's Water Resources. Utah Water Research Lab., Utah State University and Utah Div. Water Resources, Utah State Univ., Logan, Utah. $214 \mathrm{p}$.

This is a collection of papers on Great SaIt Lake as of 1972.

Riley/Utah/ Great Salt Lake/ saline/ lake/ general/ review/

Rushforth, S.R., Brotherson, J.D., Fungladda, N. and Evenson, W. E. 1981. The effects of dissolved heavy metals on attached diatoms in the Uintah Basin of Utah, U.S.A. Hydrobiologia B3: $313-323$.

The relationship of diatom species to dissolved heavy metals is described.

Rushforthl Utahl streaml diatoml chemistryl periphytonl

Rushforth, S.R., St. Clair, L.L., Grimes, J.A., and Whiting, M.C. 1981. Phytoplankton of Utah Lake. Great Basin Nat. Mem. $5: 85-100$.

Two hundred and ninety-tive species from 64 pm net $53 m p l e s$ are listed. The authors pay particular attention to diatoms and some photomicrographs are presented. Counts of cells, colonies and 
filaments per 1 iter at various times during the summer of 1974 are given. The paper updates earlier work on the species in Utah Lake.

Rushforth/ Utahl Utah Lakel freshwaterl lakel green algael blue-green algael dinoflagellatel Euglenophyta/ Chrysophytal diatom/ species list/ illustrationsl

Rushforth, S.R., St. Clair, L.L., Leslie, T.A., Thorne, K.H. and Anderson, D.C. 1976 . The algal flora of two hanging gardens in southeastern Utah. Nova Hedwigia 27: 231-323.

This is a general discussion of hanging gardens (wet seeps in clifts) in Arches and Canyonlands National Parks. It contains a good description of over 133 species of algae and their abundance.

Rushforth/ Utahl freshwaterl cliffs/ blue-green algael green algae/ Euglenophyta/diatom/ species Iist/ illustrations/

Rychert, R., Skujins, J., Sorenson, D. and Porcella, D. 1978 . Nitrogen tixation by lichens and free-living microorganisms in deserts. In West, N.E. and skujins, J., (eds). Nitrogen in Desert Ecosystems. Dowden, Hutchinson and Ross, Inc., Strandsburg, Pennsylvania, p. $20-30$.

Blue-green algae crusts and/or blue-green algae-lichen crusts can fig significant amounts of atmospheric nitrogen in desert soils, and are probably responsible for a major input of nitrogen into desert ecosystems. The crusts serve to stabilize the soil surface, to reduce erosion and to increase water retention and infiltration. Heterotrophic nitrogen fixation in arid soils is probably negligible due to the lack of available carbon. Desert shrubs appear to possess inhibitors of crust nitrogen fixation, and this inhibition may be important, particularly in the desert shrub canopy microenvironment. Although emphasis is placed on a review of available literature, some new data from Curlew Valley, Utah, are alsopresented.

Rychert/ Utah/ soil/ blue-green algael review/ lichens/ nitrogen fixationl

Rychert, R.C. and Skujins, J. 1974. Nitrogen fixation by blue-green algae-lichen crusts in the Great Basin Desert. Soil Sci. Soc. Am. Proc. 38:768-771.

BI ue-green algae-lichen crusts (Atriplex confertifolia, Eurotia lanata and Artemisia tridentata sites) from the Great Basin Desert have a laboratory potential of fixing atmospheric 
nitrogen at rates up to $89 \mathrm{~g}$ of $N \mathrm{ha}^{-1} \mathrm{hr}^{-1}$. Nitrogentiation is optimal when the crust is moistened to-1/3 bar pressure, temperature is 19 to $23 \mathrm{C}$, and the light intensity is 200 microeinsteins $\mathrm{m}^{-1} \mathrm{sec}^{-1}$. with incandescent light. The acetylene reduction technique provided a useful assay to measure nitrogen fixation which was correlated with potential values obtained in the laboratory under optimum conditions. Nitrogen fixation was found to be reduced under desert shrub canopies possibly due to allelopathic effects of the shrubs. Aqueous leaf extracts of desert shrubs significantly inhibited nitrogen fixation. Annual $N$ fixed was estimated at 10 to $100 \mathrm{~kg}$ of $N$ ha $y \mathrm{r}^{-1}$, depending upon microenviconmental conditions.

Rychert/Utah/ soil/blue-green algae/ nitrogen fixation/

Rychert, R.C. and Skujins, J. 1974. Inhibition of algal/Iichen crust nitrogen fixation in desert shrub communities. Am.

Soc. Microbial. Annu. Meeting, Abstract E 20.

Moistened algal/lichen crusts from south Curlew Valley, Utah, in the Great Basin Desert, are capable of fixing atmospheric

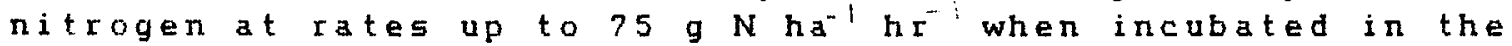
Iight, and subsequentIy assayed by the acetylene Ieduction technique. The photosynthetic inhibitor, dichlorophenyl dimethyl urea (DCMU) inhibits N-fikation. [ichen cover and N-fixation are greatIy reduced under the plant canopies of Artemisia

tridentata, Eurotia lanata and Atriplex confertifoliz. Aqueous extracts, Ieaf soak tiltrates, and volatile products from the leaves of those three desert shrubs significantly inhibit crust N... ixation. Ammonium ion inhibits crust $N$-fixation with the addition of $10 \mu \mathrm{gg}$ soil resulting in measurable inhibition of tixation. It would appear that the level of ammonium ion in the algal/lichen crust microenvironment regulates the rate of N-tixation. However, the distribution of crust, and hence nitrogen input in this ecosystem, also appears to depend upon release of inhibitors of N-fixation by desert shrubs, perhaps by plant litter fall, leachate, or dewfall.

Rychert/ Utah/ soil/ blue-green algae/ nitrogen fixation/ lichens!

Skujins, J. and KI ubek, B. 1978. Nitrogen fixation and cycling by blue-green algae - I ichen-crusts in arid rangeland soils. Ecol. Bull. (Stockholm) 26: 164-171.

In claymcontaining arid soils the major nitrogen input is by N-tixing blue-green algae of cryptogamic crusts. Nitrification and denitrification takes place in the crust microenvironment and the carbon supplied by the photosynthetic activities of the crust serves as the apparent energy source for the denitrification. Only a minor fraction of the $\mathbb{N}_{2}$ fixed may enter the soil 
for a further use by plants. N2 fixation is dependent on the available seasonal moisture and regulated by the presence of ammonium and allelochemics in soil.

Sxujins/Utah/ soil/ blue-green algae/ Iichens/ nitrogen tixationl

Snow, E. 1932. A preliminary report on the algae of Utah Lake. proc. Utah Acad. Sci. Arts and latt. $9: 21-28$.

This paper lists the species found in Utah Lake in 1930.

Snow/ Utahl Utah Lake/ freshwater/ lakel blue-green algael green a lgae/ species list/

Snow, E. and Stewart, G. 1939. A preliminary report of the algae of Mirror Lake. Proc. Utah Acad. Sci. Arts and Lett. 16: 11. 3-115.

This paper is mainly a list of species found in this lake.

Snow/ Utah/ freshwater/ lake/ blue-green algae/ Xanthophytal green algae/ Chrysophyta/diatom/dinoflagellate/ Euglenophytal species i ist/

Snyder, J.M. and Wullstein, L.H. 1973. The role of desert cryptogams in nitrogen fixation. Am. Midl. Nat.90: 257-265.

Several desert cryptogams and associated microorganisms were tested for potential nitrogen fixation using the acetylenereduction method. Ethylene accumulation was very low for most plants with values between 1.26 and 3.17 n moles ethylene $\mathrm{g}^{-1} \mathrm{mI}^{-1}$ per 15 days. The highest ethylene assays were obtained for Peltigera rufescens ( $3720 \mathrm{n}$ moles $\mathrm{g}^{-1} \mathrm{ml}^{-1}$ per 10 days), Grimmia $5 \mathrm{p}$. ( $52.3 \pi$ moles $\mathrm{g}^{-1} \mathrm{ml}^{-1} \mathrm{per} 15$ days) and Dermatocarpon lachneum miked with free-1iving Nostoc spp. (162 n moles $\mathrm{g}^{-1} \mathrm{mil}^{-1}$ per 15 days). Free-living blue-green algae, the Nostoc sp. phycobiont of $P$. Iufescens and Azotobacter-like organisms, were implicated as the nitrogen tixers. However, the role of these organisms as the major providers of nitrogen to the desert ecosystem was questioned.

Snyder/ Utahl Idahol soil/ blue-green algael nitrogen fixation/

Squires, L.E., Rushforth, S.R. and Brotherson, J.D. 1979. AlgaI response to a thermal effluent: Study of a power station on 
the Provo fiver, Utah, U.S.A. Hydrobiologia 63:17-32.

The effect of a thermal effluent on the attached a Igae of the Provo River, Utah, U.S.A., was studied from 1975 to 1977. Data for macroscopic and microscopic algae were collected and analyzed. Diatoms, Cladophora glomerata, and Hydrurus foetidus dominated the flora. The thermal effluent significantly affected the algal flora in a section of river 100 to 135 meters long immediately below the discharge point. Cladophora growth was increased and Hydrurus was absent in this area. In addition, diaton production was often higher and diversity lower than in the rest of the river. Commity structure was unique from all other adjacent areas. Small temperature increases which occurred as effluent and $r$ iver waters mixed farther downstream were apparently not as important to the algal flora as other environmental factors.

Squires/ Utah/ freshwater/ river/ diatom/ green algael

Squires, L.E., Rushforth, S.R., Endsley, C.J. 1973. An ecological survey of the algae of Huntington Canyon, Utah. Brigham Young University BuIl. 18: $1-87$.

Huntington Creek contains a wide diversity of genera and species of algae. Diatoms are the main constituent of the flora of this stream throughout the year. Hydrurus foetidus is prevalent in Huntington Creek from late winter to early summer, and filamentous blue-green algae abound in the summer and fall. cladophora glomerata, Oedogonium sp., and Chara vulgaris are abundant in the creek beyond the mouth of the canyon. Most plankton in Huntington creek originate on the substrate and in reservoirs on the left fork.

Squires/ Utah/ freshwater/ stream/ pond/ diatom/ green algael bIue-green algae/ dinoflagellate/ Chrysophytal chemistryl ecology' species Iist'

St. Clair, L.L. and Rushforth, S.R. 1977. The diatom flora of the Goshen warm spring ponds and wet meadows, Goshen, Utah, U.S.A. Nova Hedwigia 28: 353-425.

A taxonomic study of the diatoms of the coshen ponds and adjacent wet meadows, Utah County, Utah, U.S.A., was conducted from April 1974 to March 1975. The diatorn flora of these warm spring fed ponds consisted of thirty-five genera containing one hundred twenty-one species, twenty-eight additional varieties, and two additional forms. The flora was dominated primarily by the genera Achnanthes, Eragilaria, Synedra, Navicula, Cymbella, Terpsinoe, and Nitzschia.

5t. Clair/Utah/ freshwater/ spring/ pond/ diatom/ species list/ 
St. Clair, L.E. and Rushforth, S.R. 1976. The diatoms of Timpanogos Cave National Monument, Utah. Am. J. Bot.63: 49.59 .

The diatom flora of the cavern system of Timpanogos Cave National Monument was investigated. Diatoms were found throughout the cave system and were distributed according to moisture and natural openings. Twenty-six species were identified and described, iflcluding eight not previously collected from caves and four new records for the state of Utah.

St. Clair/Utah/ freshwater/cavel soil/diatom/ species Iist/ il Iustrationsl

St. Clair, L.L. and Rushforth, S.R. 1978. The diatom flora of the Goshen PIaya and wet meadow. Nova Hedwigia $29: 191-229$.

Diatoms from a playa (dry lake) in Utah are discussed and the species are I isted

St. CIair/Utah/ freshwater/playa/meadow/ soil/diatom/ ecologyl species Iist/ illustrationsl

St. CIair, L.L., LesIie, T.A. and Whiting, M. 1974. The algal standing crop of Utah Lake. Proc. Utah Acad. Sci. 51: 75.

This paper (an abstract) contains very little information - iust a description of methods.

St. Clair/ Utah/ Utah Lake/ freshwaterl lakel green algael bI ue-.green algael diatom/

Stephens, D.W. 1974. A summary of biological investigations concerning the Creat Salt Lake, Utah. Great Basin Nat. 34: $221-229$

The early stages in the history of biological investigation of the Great salt Lake involved the identification and establishment of taxonomic relationships of the indigeous flora and fauna. A result of advancements in systematic biology is that many of the earlier names of organisms have been placed in synonomy. Recent interest in the lake has centered on biological productivity and interactions of components of the ecosystem. The creation of two ecologically distinct lakes by the construction of a railroad causeway has further enhanced the 
biological complexity of what was originally believed to be a lifeless body of brine.

Stepinens/ Utah/ Great Salt Lake/ salinel lake/ green algael blue-green a Igae/diatom/ generall reviewl

Stephers, D.W. and Gillespie, D.M. 1976. Phytoplankton production in Great salt Lake, Utah and a laboratory study of algal response to enrichment. Limnol. Oceanogr. 21: $74-B 7$.

The annual production in the southern basin of the Great Salt Lake as estimated at two stations in 1973 averaged 1459 c. $\mathrm{m}^{-2}$. The majority of the production occurred during March and April and was due to an unidentitied species of Dunalielia. Daily carbon $t$ ixation rates averaged $2.13 \mathrm{~g} \mathrm{c} \mathrm{m}^{-2}$ at both locations during this period. A minor phytoplankton bloom in August, due to a small, unidentified green flagellate contributed $5 \%$ of the total annual phytoplanktor production. Pliytoplankton production was probably limited during April by self-shading and during the remainder of the year by the availability of nitrogen, as shown by laboratory bioassays. Grazing by Artemia salina reduces the phytoplankton population in late summer when nutrient levels have partially increased due to regeneration. The miromictic character of the Iake was indicated by profiles of temperature and density. The monimolimnion is postulated to act as a nutrient sink, reducing the rate of nutrient release to the mixolimnion.

Stephens/Utah/ Great Salt Lake/ saline/ lake/greenalgael chemistry/ production

Stephens, D.W. arid Gillespie, D.M. 1972 . Community structure and ecosystem analysis ot the Great Salt Lake. In Riley, J.P., (ed). The Great Salt Lake and Utah's Water Resources. Utah Water Research Lab., Utah State Univ. and Utah Div. Water Resources, Utah state Univ., Logan, Utah. p66-72.

The construction of an earthfill causeway across the Great salt Lake resulted in development of two basins within the lake. The northern basin supports a depauperate biota consisting primarily of an alga, Dunalielia salina, several protozoa, and bacteria. The southern basin exhibits two energy flow systems with only minor interactions: The planktonic system with a single phytoplankter, (Dunaliella viridis), anda single zooplankter, (Artemia salina); and a benthic system of blue-green alga (coccochloris elebans), detritus, and brine fly larvae, (Ephydra). The only outflow from either system occurs when birds teed upor the shrimp or fly larvae. The Dunalielia population seems to be limited early in the calendar year by temperature and light. Dunaliella viridis reaches its peak population 
density $\left(24\right.$ x $10^{5}$ 1iter) in April and its decline to less than rapidiy expanding Artemia salina population. The availability of the nutrients nitrogen and phosphorous does not seem to be a Iimiting factor for Dunalielia.

Stephens/ Utah/ Great Salt Lakel salinel lakel green algat blue-green algae/ ecologyl succession/ zoologyl

Stewart, A.T. and BIinn, D.W. 1976. Studies on Lake Fowe11, U.S.A.: Environmental tactors influencing phytoplankton success in a high desert warm monomictic lake. Arch. Hydrobiol. $78: 139-164$.

Limnological studies were conducted on lower Lake Powell, a large desert reservoir in southwesten USA. Warm Creek Bay was tound to $E$ e a warm monomictic system that initiated overturn in mid $\cdots$ october to early November. Restratification started about the end of April. Summer thermal stratification led to a zone of oxygen depletion below 15 meters $3 t$ the two deepest stations. The pattern of seasonal algal succession was typical ot that found in many moderate-sized temperate lakes - a spring diatom pulse (Fragilaria crotonensis and Asterionella formosa), a diverse phytoplankton summer community (Dinobryon sertularia and Chloroccocalean), a Iate autum diatom (synedra delicatissima var. Angustissima) increase and a pronounced winter phytoplankton paucity. Correlation coefficients implicated water temperature as an eatremely important regulator of phytoplanktor density in Warm Creek Bay. Concentrations of nitrogen compounds often correlated significantly with both total number of phytoplanktor cells and individual species.

Stewart/ Utah/ Arizonal freshwater/ lakel diatom/ green algael dinotlageliate/ Euglenophyta/ physics/chemistry/ species Iist/ succession/

Stewart, A.J. and Blinn, D.W. 1974. Phytoplankton population dynatoics in Warm Creek Bay, Lake Powell. J. Phycol. 10(supp 1): 11 .

Seasonal and Jepth distributions of phytoplankton and selected physio-chemical parameters were followed for a 13 month period in the relatively new Lake Poweli reservoir. Three sampling stations, averaging 5,20 , and 40 meters in depth were established along a transect in Warm Creek Bay. A spring diatom maximum (Eragilaria crotonensis, Asterionella formosa) was succeeded almost immediately by a long pulse of Dinobryon sertularia. Three species of Scenedesmus showed temporal and spatial niche differentiation. Overturn conditions in october terminated the development of populations of some warm-water species (Peridiniun willei, Ceratium hirundinella), while Synedra sp. flourished during the winter months. A strong 
corlelation was found between the mean depth of each station and the abundance of some species - E. crotonensis favored the deepest station while the dinoflagellates and a species of Euglena preferced the shallowest station. Nitrate and phosphate levels were highest atter spring rains. The formation of a pronounced thermocline allowed the development of a zone of oxygen depletion ( $2.0 \mathrm{mg} 1^{-1}$ ) during the summer months, and pH values were generally lower during the winter months.

Stewart/ Utah/ Arizona/ freshwater/ lake/ diatom/ Euglenophyta/ green a lgael dinoflageliate/ successionl

Tanner, V.M. 1931 . Fresh Water biological studies at Utah lake No.2. Proc. Utah Acad. Sci. Arts and Lett. B: 199-203.

The genera of algae in Utah Lake as of 1931 are listed. Some chemical data is also included.

Tanner/ Utah/ Utah Lake/ freshwater/ lake/ green algael bI ue-green algae/ diatom/ dinoflageliatel chemistry/ specis $\mathbf{s}$ ist/

Tanner, V.M. 1930. Fresh Water biological studies at Utah Lake, Utah. Proc. Utah Acad. Sci. Arts and Lett. 7:60-61.

Genera of algae found in Utah Lake in about 1930 are Iisted.

Tanner/Utah/ Utah Lake/ freshwater/ lake/ blue-green algael green algael diatom/ species listl

Van Auken, O.W. and McNulty, I.B. 1973. The effect of envirommental factors on the growth of a halophytic species of algae. Biol. Bull. 145:210-222.

A halophilic species of Dunaliella was isolated from the creat Salt Lake, Utah, and established in axenic culture. A balanced culture media was developed containing major and minor elements as well as sufficient concentration of an osmotic agent. The effects of various environmental factors on the growth of this species ot algae were investigated and optimum growing conditions were delineated. Optimum conditions for growth of this species are as follows: 1) temperature 32 C; 2 ) NaCI $19.2 \%$ (w/v); 3) carbon dioxide $1-2 \%$ at a rate of $2.2 \mathrm{mI}^{-1} \mathrm{~min}^{-1} \mathrm{mI}^{-1}$ of culture media; 4) light intensity 25-35 KIun; and 5) pH 5.8-6.5. The $\mathrm{K}+\mathrm{Na}+\mathrm{Natio}$ should not be more than one, and better growth took place when this ratio was less than 0.1. The specific growth constant for this halophyte under the above conditions was $0.069 \mathrm{hrs}^{-1}$, which is equal to a doubling time of $10.0 \mathrm{hrs}$. 
Van Auken/ Utah/ Great Salt Lakel salinel lakel green algael cultures/ environmental factors/

West, N.E. and $5 k u j i n s, J .1977$. The nitrogen cycle in North American cold-winter semi-desert ecosystems. Oecol. Plant. $12: 45-53$.

A five year effort by a US-IBP Desert Biome group produced a comprehensive understanding of the nitrogen cycle in salt desert shrub dominated ecosystems in the N.E. part of the Great Basin Desert region of the U.S. Net physical transfers are minor in these systems. Biological processes are more important and unique. Blue-green algal components of soil cryptogamic crusts have been found to be able to fix comparatively high ${ }^{\sim 2} 25$ $\mathrm{kg} \mathrm{ha} \mathrm{ar}^{-1}$, amounts of $\mathrm{N}$, however, over $70 \%$ of this is lost through volatilization and denitrification. Only about $12 \mathrm{~kg}$ $N h a^{-1} y^{-1}$ is taken up by new above ground vascular plant growth. Very little animal export of nitrogen occurs from these systems. This basic research had led to testing of additions of carbon, nitrification inhibitors, and fertilizer $N$ amendments as means of increasing tlow of nitrogen into primary production.

West/Utahl soil/ blue-green algael nitrogen cyclel

White, D.A., Barton, J.R., Bradshaw, J., Smith, C.S., Sundrud, R.B. and Harding, W.J. 1969. The changing biota of Utah Lake. Proc. Utah Acad. Sci. Arts and Lett. 46:133-139.

Biological conditions of Utah Lake in 1850 are compared with conditions in 1969

White/ Utah/ Utah Lake/ freshwater/ lake/ blue-green algael dinoflagellatel zoologyl

Whiting, M., Leslie, T. and St. Clair, L. L. 1974. The non-diatom algae ot Utah Lake. Proc. Utah Acad. Sci. 51: $73-74$.

Seasonal changes in the populations of Utah Lake are described.

Whiting/ Utah/ Utah Lakel freshwater/ lake/ green algael blue-green algael dinotlagellateldiversityl successionl

Whiting, M.C., Brotherson, J.D. and Rushforth, 5.R. 1978 . Environmental interaction in summer algal communities of Utah Lake. Great Basin Nat. 38: 31-41. 
Phytoplankton samples and environmental data were taken from June through August 1974. Phytoplankton species were identified and then quantified in a Palmer counting cell. Environmental continuum theory was employed to describe algal succession, and regression analysis was used to discover interactions between a Igal communities and the environment. Phytoplankton communities in June were chatacterized by high species diversity. As the lake envicorment became stressed in late summer due to higher turbidity, nutrient levels, pH, and available inorganic carbon species diversity decreased. By August, the phytoplankton flora was composed essentially of only two species, Ceratium hicundineIla and Aphanizomenon flos-aquae.

Whiting/ Utah/ Utah Lake/ freshwater/ lake/ chemistry/ diversitylenviconmental factors/

Williams, L. R., Hern, S.C., Lambou, V.W., Morris, F.A., Morris, M.K. and Taylor, W.D. 1979. Distribution of phytoplankton in Utah lakes. U.5. Environmental Protection Agency, Ecol. Res. Ser. Rept. No. EPA-600/3-79-120. v+65p.

This is a data report presenting the species and abundance of phytoplankton in the 25 lakes sampled by the National

Eutrophication survey in the State of Utah. Results from the calculation of several water quality indices are also included (Nygard's Trophic State Index, Palmer's Organic Pollution Index, and species diversity and abundance indices).

Williams/ Utah/ freshwater/ Iake/ blue-green algael diatom/ green algael dinoflageliate/ Euglenophyta/ Chrysophytal Cryptophyta/ species I ist/ diversityl

Woodbury, A.M. 1933. Biotic relationships of Zion Canyon, Utah with special reference to succession. Ecol. Monogr. 3: $146-245$.

Species that occur in springs and streams at zion are listed.

Woodburyl Utah/ freshwater/ 5pringl stream/ biue-green algael green algael diatom/ species list/

Woodbury, A.M. 1959. Ecological 5 tudies of the flora and fauna in Glen Canyon. Anthropological Papers, GIen Canyon Ser. No.7, Dept. of Anthropology, Univ. of Utah. $226 \mathrm{p}$.

This is a collection of papers on GIen canyon before its impoundment as Lake PoweII.

Woodburyi Utah/ Arizona/ treshwater/ river/ general/ review/ 
Young, 0.W. 1947. Notes on periphyton of Ogden River. Proc. Utah Acad. Sci. Arts and Lett. $24: 137$.

This is a short abstract describing preliminary studies on attached algae of the Ogden River.

Young/Utah/ freshwater/ river/ diatom/ green algael blue-green algael periphytonl

Young, O.W. 1948. Observations on periphyton of Ogden River. Proc. Utah Acad. Sci. Arts and Lett. 25: 171-172.

Eurther work (an abstract) describes species occurring on rocks in Ogden River.

Yourg/ Utahl freshwater/ river/diatom/ green algael periphytonl species Iist/

ZahI, P.A. 1967. Lite in a "Dead" Sea - Great Salt Lake. Nat. Geogr. $132: 252-265$.

This is a popular article on all aspects of Great salt Lake which includes discussion of Dunalielia, brine shrimp and birds.

Zahl/Utah/ Great Galt lake/ saline/ lakel green algael diatom/ general/ reviewl illustrationsl 


\section{SECTION 8. 1}

RELATED HABITAT PAPERS: UTAH

Bott, C. and Shipman, S.T. 1971. Water chemistry and water quality of Farmington Bay. In Carter, C.K., (ed). Some ecological considerations of the Farmingtor Bay Estuary and adjacent Creat Salt Lake State Park. Univ. of Utah, SaIt La $k \in C i t y, U t a h . P . B-1-B-27$.

As a result of the sos studies done during the summer of 1971 , a baseline study is now ayailable on the water chemistry to which future researchers can refer. In addition, several conclusions have been drawn about conditions in the bay. Ferhaps most important is that it is an area showing great variance in salinity, both vertically and horizontally, ranging from a low of $0.5 \%$ to a high of $12 \%$. The temperature of he bay was also shown to vary almost daily as a function of air temperature. A Iso of interest were the tests run to determine water quality, showing that the bay is polluted not only with respect to coliforms (See sos section C) but also with phosphates (and therefore algae) and detergents.

Bott Utah/ Great SaIt Lake/ chemistryl not algael

Brues, C.T. 1932. Further studies on the tauna of North American hot springs. Am. Acad. Arts and Sci.67: 186-303.

There is no information given on algae, but there are good descriptions of numerous hot springs in the west.

Brues/ Nevada/ California/ Utah/ salinel freshwater/ springl zoologyl thermal habitat/ not algael

Butts, D. S. 1977. Solar evaporation chemistry of Great Salt Lake brines. In Greer, D.C., (ed). Desertic Terminal Lakes. Utah Water Research Lab., Logan, Utah.

No information on algae is given, but this paper presents a good description of how various ions precipitate from Great salt Lake.

Butts/ Utah/ Great Salt Lake/ salinel lakef chemistryl not a I gael

Farnsworth, R.B. and Martin, T.L. 1937. Studies of some of the biological characteristics of the virgin soils in Utah 
Valley at the western base of the Wasatch Mountains. Proc. Utah Acad. Sci. Arts and Lett. 14: 27.

This is a short abstract describing studies of nitrifying bacteria and fungi. Eungi genera are listed.

Earnsworth/ Utahl soil/ fungi/ not algael

Hansmann, E.W., Kidd, D.E. and Gilbert, E. 1974. Man's impact on a newly formed reservoir. Hydrobiologia 45: 185-197.

A newly formed reservoir in the southwestern United states was analyzed for man's impact on the eutrophication of impoundment. The anlysis of the carbon-14 net productivity indicated that the area studied was naturally eutrophic. Significant differences in net production were observed among the sites, as the area where man's recrational activities are highly concentrated had a significantly higher production rate than the other sites investigated. Mean monthly estimate of production for all the sites, and monthly and yearly estimates for the area studied are included.

Hansmann/ Jtah/ freshwater/ lake/ production/ not algael

Lin, A., Chang, P. and Sha, P. 1972. Some physi-chemical characteristics of the Great Salt Lake. In Riley, J.P., (ed). The Great Salt Lake and Utah's Water Resources. Utah Water Researoh Lab., Utah State Univ. and Utah Div. Water Resources, Utah State Univ., Logan, Utah. p-65.

Results of some work done on the Great salt Lake during the summer months of 1972 are presented. The detailed vertical profiles of temperature, dissolved oxygen, conductivity and pH values were measured among 17 buoy stations installed at the south end of the lake. Several phenomena related to the deep brines of the Iake seem to indicate some clues for the source of deep brines of the Great Salt Lake. Comparative study between the Great salt Lake and the Dead Sea has proven to be very informative both in the mineral and the hydrological aspects of the two similar bodies of water.

Linl Utah/ Great $5 a$ It Lake/ saline/ lake/ chemistry/ not algael

Feale, A.C. 1886 . Lists and analyses of the mineral springs of the United 5 tates. Bull. U.S. Geol. Surv. No.32, Washington, D.C. $235 \mathrm{p}$.

This paper lists the locations and the status of many saline spirigs in the United States, especially in the West. Nothing on 
a 1 ga e.

Peale/ Idahol Utah/ Arizona/ New Mexicol CaIifornial Oregonl Montana/ Wyoming/ Nevada/ Colorado/ saline/ spring/chemistry/ genera $1 /$ guidebook/ not algae/

Sturm, P.A. 1980. The Great Salt Lake brine system. In Gwynn, J.W.. (ed). Great Salt Lake, a Scientific, Historical, and Economic Overview. Utah Geological and Mineral Survey Bull. No.116. p147-162.

Data on the chemical composition of Great $5 a 1 t$ lake is given. This paper cites several other studies of chemistry.

Sturm/Utah/Great Salt Lake/ saline/ lake/ chemistryl not a I gael

Sturm, P.A., McLaughlin, J.C., and Broadhead, R. 1980 . Analytical procedures for Great Salt Lake brine. In Gwynn, J.W., (ed). Great Salt Lake, a Scientific, Historical, and Economic Overview. Utah Geological and MineraI Survey Bull. No. 116. p $175-193$.

Analytical procedures for chemical elements are given.

Sturm/ Utah/ Great salt Lake/ saline/ lake/ chemistryl not a $l g a e l$

TayIor, E.L., Hutchinson, L. A. and Muir, M.K. 1977. Heavy Metals in the Great Salt Lake, Utah. Utah Water Research Lab., Logan, Utah. P. 109-124.

This paper contains nothing on algae but it provides useful information on their habitat in Great salt Lake.

Taylor/ Utah/ Great Salt Lake/ salinel lakel chemistryl not algael

Taylor, P.L., Hutchinson, L.A. and Muir, M.K. 1980. Heavy metals in the Great SaIt Lake, Utah. In Gwynn, J.W., (ad). Great SaIt Lake, a Scientific, Historical, and Economic Overview. Utah Ceological and Mineral Survey Bul1. No.116. p.195-200.

Chemical data on various metals are given.

Taylor/ Utah/ Great SaIt Lake/ salinel lakel chemistryl not a I a el 
Whitehead; H.C. and Feth, J.H. 1961. Recent chemical analyses of waters from several closed-basin lakes and their tributaries in the western United States. Bull. Geol. Soc. Am. 72 : $1421-1426$.

This paper is a general review of the chemistry of saline lakes in the West. Chemical characteristics of the lakes are described without specific chemical data.

Whitehead/California/ Nevada/ Oregon/ Utah/ saline/ Iake/ chemistry/general/ not a $1 \mathrm{gael}$ 
SECTI ON 9.0

OTHER ALGAL PAPERS

Anderson, G.C. $1958 \mathrm{~b}$. Some limnological features of a shallow saline meromictic lake. Limnol. Oceanogr. 3: 259-270.

A discussion ot a blue-green algal mat. Hot Lake, a shallow saline body of water occupying a former epsom salt exavation in north central Washington is meromictic and during the period of study had an average salt gradient of approximately 100 g $1^{-1}$ at the surface to $400 \mathrm{~g} \mathrm{I}^{-1}$ at the bottom. The major salt was magnesium sulfate. The mixolimnion was thin enough that the monimolimnion was heated directly by the sun, with the result that temperatures in excess of $50 \mathrm{C}$ were recorded in the monimolimnion during summer. Much of this heat was retained during the winter. The calculated value of heat gain in the monimolimion agreed reasonably well with the observed value. The flora consisted mainly of Chara, a bottom mat of bIue-green algae, and a dense population of green sulfur bacteria in the upper part of the monimolimnion. Artemia salina was the dominant coolankter, and some features of its life history as affected by the unusual thermal properties of the lake are described.

Anderson/ Washington/ salinel lake/ blue-green algae/ chemistryl

Andersor, G.C. 1958 . Seasonal characteristics of two saline lakes in Washington. Limnol. Oceanogr. 3: 51-68.

The limnology of two highly saline lakes in washington was studied in relation to the physical and chemical conditions which influence the growth and distibution of phytoplankton. Morphometric conditions were determined, and routine sampling included medsurements of temperature, transparency, oxygen, pH, a lkalinity, phosphate, chlorophyll, and quantitative samples of phytoplankton. Lake Lenore, the less saline of the two (T.D.S. $\left.149 i^{-1}\right)$, is 5 hallow and was unstratified during the investigation. Dissolved nutrients were high and showed erratic variations during the summer. The phytoplanktor population was taxonomically simple and was made up mainly of two species of diatoms Amphora sp. Which formed the spring bloom, and Chaetoceros elmorei which made up the late summer bloom. Soap Lake is tairly deep, meromictic, and 5 aline (T.D.S. 35 g $1^{-1}$ ). Temperature conditions were dichothermic, and the nutrient content was high, especially in the monimolimnion. A winter maximum and a summer minimum was observed in the phytoplankton population, and a change in the biota has been noted during dilution of the lake in recent years. Inaication of grazing by aooplankton was found in both lakes.

Andersonl Washingtonl salinel lakel diatoml green algael 
blue-greeth algae/ chemistry/ species Iist/ successionl nutzients/

Avron, M. and Ben-Anotz, A. 1979. Metabolic adaptation of the alga Dunalielia to low water activity. In Shilo, M., (ed). Strategies of Microbial Life in Extreme Environments, VerIag Chemie, Weinheim. p. 83-91.

A hypothetical mechanism for osmoregulation viz conversion of stored polysaccharides to giycerol in response to an increase in sat concentration, and vice versa, has been put forward. Two new enzymes NADPH-dihydroxyacetone-reductase and dihydroxyacetone..kinase, which seem to be involved in the osmoregulation response via glycerol, have been isolated and characterized.

Avron' saline' green algael Dunaliellal

BIinn, D.W. 1970. The influence of sodium on the development of ctenociadus circinnatus Borzi (Chlorophyceae). Phycologia 9: $49-54$

Ctenocladus eifcinnatus Borai is a filamentous green alga restricted to highly saline solutions where Na is the dominant cation. Investigations on the influence of various salt solutions were conducted primarily on akinetes, as this stage is important in maintaining populations of Ctenocladus in extreme natural saline solutions. The Na/Mg ratio andlor Naltotal cation ratios are probably more significant in growth and development of Ctenociadus than the monovalentl divalent total cation ratio. Vegetative cells of ctenocladus were much reduced and irregular when cultured in solutions with Na/Mg ratios below 1.3. Increasing $\mathrm{Na} / \mathrm{Mg}$ ratios showed normal growth and development with cells possessing a typical laminate chloroplast. The Na/Mg ratios most successful for culturing ctenocladus in the laboratory correspond closely to those ratios found in natural solutions with Ctenocladus. Studies also indicate that Na may be a physiological requirement during certain stages of development ( $i . e$. akinete germination) for this alga. Germination of akinetes only occurred in Na salt solutions whereas other major cation salt solutions resulted in destruction of the akinetes.

BIingl British CoIunbial salinel lakel green algael culturesl i 1 Iustrationsl

BIinn, D.W. 1971. Autecology of a filamentous alga, Ctenocladus circinnatus (Chlorophyceae) in saline environments. Can. J. Bot. $49: 735-743$.

Six highly saline habitats in arid regions of British Columbia, 
Nevada, and California with the chaetophoralean Ctenocladus cireinnatus Borzi were irvestigated to characterize the unique environment of this alga. Seasonal patterns within three of these habitats were aralyzed to reveal those parameters determining the restricted distri bution of Ctenocladus. Sodium was the dominant cation in combination with any major anion, such as sulfate, carbonate and bicarbonate. Seasonal salinity fluctuations of the water solutions were large ( $10-\rangle 100$ millimos). Ctenocladus tolerated these high salinities and temperatures (-3 to $28 \mathrm{Ci}$ as akinetes formed early in the summer and they survived as akinetes until dilution of the water solutions the next spring. The period for optimum vegetative development was short (6-12 weeks) because of an increase in salinity and temperature of the waters. Akinete germination in the lab was optimal between 9 and 26 C and temperatures above 34 C destroyed a kinetes. Conversely, the freezing of akinetes produced no adverse atfects. Laboratory studies showed germination and vegetative development retarded at pH below 8.0 with akinetes destroyed below 7.0. Light is essential for germination with low light intensities (214 lux) stimulating germination. Light intensities above 12000 lux destroyed akinetes within 5 days. Sexual reproduction in both the field and laboratory was absent. The significance of the akinete and lack of sexual reproduction are correlated with laboratory and field data and the restricted distribution of Ctenociadus.

BIinn/ British Columbia/California/ Nevada/ saline/lake/pond/ green algael chemistry/ environmental factorsl ecologyl

BIim, D.W. and Stein, J.R. 1970. Distribution and taxonomic reappraisal of Ctenocladus (Chlorophyceae: Chatophorales). J. Phycol. 6: 101-105.

The distribution of the rare filamentous green alga Ctenocladus Borzi was examined on a world-wide basis. All the collection sites are restricted to specific inland habitats. Most of these locations are in arid regions of North America with a few scattered sites in Peru, Sicily, and siberia. This alga has been referred to 2 genera, either Ctenocladus or Lochmiopsis Woronochin \& popova, tor the past 45 years. Based on field observations, laboratory cultures, and herbarium material, Lochmiopsis is considered synomymous with ctenocladus. The Iesponse of vegetative cell dimensions to seasonal changes (i.e., osmotic potential and temperature) in 3 saline habitats in British Columbia was also investigated. Results fiom the study, along with laboratory dilutions of natural saline waters, showed that cell dimensions are not valid criteria for sepirating species of ctenocladus as proposed by some authors. Consequently ctenocladus is considered a monotypic genus with physiological variants responding to seasonal environmental conditions. (In North America this alga has been collected at Mono Lake and Borax Lake, California; Green Pond and Red Pond, Arizona; Abert Lake, Oregon and at several locations in British 
columbia. [solates from the latter locations are illustrated).

BIinn/ British Columbial CaIifornial Oregon/ Arizonal Nevadal saline/ lake/ pond/ green algae/ taxonomy/ illustrations/

Bold, H.C. and Wynne, M.J. 1978. Introduction to the Algae: Structure and Reproduction. Prentice-Hall, Inc., Englewood CIiffs, N.J. 706 .

This is is good general text on the algae.

Bold f feshwater/ saline/ general/ tanonomy/ illustrations/

Bolke, E.I. 1979. Dissolved-oxygen depletion and other effects of storing water in Elaming Gorge Reservoir, Wyoming and Utah. U.S. Geol. Surv. Water-Supply Pap. No. $2058.41 \mathrm{p}$.

In this paper, dissolved oxygen changes are discussed. An algal species occurring in a bloom in 1975 is mentioned.

Bolke/ Wyomingl Utahl freshwater l lake/ blue-green algael green algae/ diatom/ chemistry/ species list/ bloom/

Borowitzka, L.J. and Brown, A.D. 1974. The salt relations of marine and halophytic species of the uniceliular green alga, Dunalielia. The role of glycerol as a compatible solute. Arch. Microbiol. 96: 37-52.

Comparisons were made of the effects of salt on the exponential growth rates of two uniceliular algae, Dunaliella tertiolecta (marine) and Dunaliella vicidis (halophilic). The algae contained glycerol in amount which varied directly with the 5 alt concentration of the growth media. The highest measured glycerol content of D. tertiolecta was approximately equivalent to 1.4 . molal and occurred in algae grown in $1.36 \mathrm{M}$ sodium chloride. The highest glycerol content measuredin D. viridis was approximately eqivalent to 4.4 molal and occurred in algae grown in 4.25 M sodium chloride. Lower concentrations of free glucose, which varied inversely with extraceliular salt concentration, were a 150 detected. It is inferced that $\mathrm{Nat}$ is effectively excluded from the two algae. There was some evidence of a moderate uptake of $K+$. Comparisons were made of crude preparations of the glucose-6-phosphate dehydrogenase and an NADP-specific glycerol dehydrogenase from each species and of the effects of salt and glycerol on the activities of these enzymes. It is concluced that the different salt tolerances of the two algae cannot be explained by generalized differences between their enzyme proteins. Although intraceliular glycerol must necessarily contribute to the osmotic status of the algae, its primary 
tunction in influencing their salt relations is considered to be that of a compatible solute, whereby glycerol maintains enzyme activity under conditions of high extracellular $5 a 1 t$

concentration and hence low (thermodynamic) water activity.

Borowitzka/ saline/ green a lgae/ biochemistry/ Dunaliella/

Borowitzka, L.J. 1981. The microflora: Adaptations to life in extremely saline lakes. Hydrobiologia 81 : 33-61.

This paper lists salinities at which Dunaliella and some blue-green algae have been found; also optimum temperatures ( 32 C for Dunalielia) are given. This paper is a good general discussion and review of Dunaliella - distribution, cytology and reproduction, salinity tolerance, temperature, light intensity, pigmentation, work on this 5 pecies from Australian lakes (and elsewhere). This paper is a Iso a good general discussion of blue-green algae from saline lakes as above for Dunaliella. Many citations are given.

Borowitakal salinel lake/ green algaef blue-green algael general/ Dunaliella/ temperature/ light/

Brock, T.D. 1975. Effect of water potential on a Microcoleus (Cyanophyceae) from a desert crust. J. Phycol. 11: 316-320.

The etfect of water potential on the growth and photosynthesis of a species of Microcoleus forming a desert crust was determined, using both osmotic and matric variations in water potential. The alga was quite sensitive to moisture stress, partial inhibition of growth being observed at -7 bars, and complete inhibition at -18 bars. Photosynthesis was markedly inhibited at -18 bars, and virtually completely at -28 bars (water potential of seawater) and lower. The alga was more sensitive to matric reduction in water potential than osmotic. By comparisons of these results with those obtained with other algat, it is concluded that this desert crust alga is rot especially adapted to grow and photosynthesize at low water potentials, although it shows considerable ability to survive severe drought conditions.

Brock/ Idahol freshwater/ soil/ blue-green algae/

Brock, T.D. 1979. Ecology of saline lakes. In Shilo, M., (ed). Strategies of Microbial Life in Extreme Environments, Verlag, Chemie, Weinheim. p29-47.

This paper discusses kinds of alga found at various salinities and ists the chemical compositions of various saline lakes. 
Brockl salinel Iake/ blue-green algael green algaeldiatoml chemistryl ecologyl generall

Castenholz, R.W. 1960. The algae of saline and freshwater lakes in the lower Crand Coulee, Washington. Washington State Univ. Res. Stud. $28: 125-155$.

The non-planktonic algae of saline and freshwater lakes in the Lower Grand Coulee were collected in 1954, '55, and 156. The 5 alinity of the saline lakes was $3-8$ ppt (Alcove), 7.5 ppt (Lenore), $16 \ldots 21$ ppt (TaIus) and 21 ppt (Soap). They are of the carbonate type. The freshwater lakes ranged from 0.25 ppt (Ealls) to 0.4 ppt (Alkali). The saline flora was depauperate in a number of taxa (36--Alcove, 30--soap), but in terms of mass, there were large amounts of benthal blue-green algae (forming a shifting mass of bentho-plankton) and diatoms with blue-greens torming epilithic coatings. The dominant diatoms in one or more of the saline lakes included Amphora acutinscula, A. Salina, Anomoconcis polygramma, A. sphaerophior, Campylodiscus clypeus, Nitzschia frustulum vars., and N. kuetzingiana. BIue-green dominants included Amphithrix janthina, Anabaena californica, Anacystis marina, A, montana, Calothria, parietina, Nodularia sphaerocarpa, plectonema nostocorum, and spiculina subsalsa. Most of the blue-greer algae showed little seasonality, but the majority of the diatoms were most abundant during the colder periods. The freshwater flora consisted of over 240 species and visieties of a $1 \mathrm{gae}$. Blue-green algae were most abundant during the summer as epiphytes in the marshes, as benthal mats in the open part of the lake, as epilithic crust-formers, and as phytoplankton. Creen algae were also very common during the warmer months in most habitats. Spirogyra formed dense benthal mats in the open lake and marshes. Cladophora was the dominant epilithic and epiphytic green alga. Diatoms were mainly epilithic and epiphytic and formed thick yellow-brown slime covers on rocks and macrophytes during spring and fall primarily. The salinity tolerances of various species of diatoms are discussed on the basis of their distribution in lakes of the Lower Grand Coulee, Saskatchewan, North Dakota, and eastern oregon. With the continued salinity decrease in two of the crand coulee lakes, a considerable change in their flora should be expected.

Castenholal Washington/ salinel freshwaterl Iakel Elve-green algae/ green algael diatom/ Euglenophytal xanthophyta/ Chrysophyta/ Cryptophytal dinoflagellatel chemistry/ species 1 ist/

Cole, G.A. 1968 . Desert Limnology. In Brown, Jr., G.W, (ed). Desert Biology, Vol.I. p. $423-486$. 
This is an update of an earlier paper by cole (1963) but consists of a more general and world-wide discussion. There is more discussion of fauna than algae.

Cole/ salinel freshwater/ lake/ streaml pool/ springl blue-green algael green algael physics/ chemistryl geologyl general/reviewl

Edmondson, W.T. 1963. Pacific Coast and Great Basin. In Frey, D.G., (ed). Limnology in North America, Chpt. 13, p.371-392. Univ. of Wisc. Press, Madison, Wisconsin.

This is a general review of the limnology of this area. Some listings of algae are included.

Edmondson/ California/ Oregon/ Washington/ Nevadal Utahl salinel treshwater/ lake/ river/ pond/ chemistry/general/ review/

Eriedmann, E.I. and Galun, M. 1974. Desert algae, Iichens, and tungi. In Brown, Jr., G.W., (ed). Desert Biology, VoI.II, Acaderic Press, N.Y. P. 165-212.

This is a review of soil and rock algae in various desert areas of the world. Algae in desert aquatic habitats are rot ment i oned.

Eriedmant soil/ rocks/ bive-green algael green algae/generall review/ nitrogen fixition/

Hammer, U.T. 1981 . Primary production in saline lakes: a review Hydrobiologia $81: 47-57$.

This is a general review of primary production in saline lakes in various parts of the world.

Hammer/ salinel lake/ chemistry/ productionl

Hedgepeth, J.W. 1959. Some preliminary considerations of the biology of inland mineral waters. Arch. Oceanogr. Limn. 11(supp 1): $111-141$.

Orgaric life of some kind or another is found in waters of extremely low pH (1,8), or in salinities up to total saturation, and even in crude oil. As yet, however, information about the tauna (and flora) of various types of inland mineral waters is still too fragmentary to penit a useful classification of such waters on a biological basis. In some of these environments, a 
limited, specialized fauna may attain a very high biomass, and they represent comparatively simple ecosystems that should be of gxeat interest for trophic studies. A provisional classification is offered: A. Hypersaline lagoons, having permanent or

intermittent connection with the sea and inhabited by maring or brackish water organisms; B. Relict waters, in which the presence of marine organisms sows a former connection with the sea; $C$. Salterns and inland orines, containing principaliy sodium chloride, inhabited by Dunalielia, Artemia and Ephydra; D. Carbonate ard sulfate waters; E. Miscelianeous.

Hedgepeth/ salinel grean algael dinoflagellatel chemistryl review/

Kemmerer, G., Bovard, J.F., and Boorman, W. R. 1923. Northwestern lakes of the United States: Biological and chemical studies with reference to possibilities in production of fish.

Eish. Bull., U.S. Nat. Mar. Fish. Serv. 39: 51-140.

rhis is mostly a discussion of fish and invertebrates. There are some algal counts. The lakes are not realiy in the desert.

Kemmerer/ Oregon/ Washington/ Idahol Californial freshwater/ Iakel blue-green algael green algael diatom/ chemistryl

Kuliberg, R.G. 1977. The effects some ecological factors on cell size of the hot sping alga synechococcus Iividus

(Cyanophyta). J. Phycol. 13:111-115.

The total dissoived substances increases gave longer cel is at 70-74.5 degrees centigrade, but not at lower temperatures. This was a field study of 30 thermal springs.

KuIlberg/ Colorado/ Idaho/ Montana/ Wyoming/ freshwater/ springl blue-green a lgael chemistry/ diversityl thermal habitat/

Lee, R.E. 1980. Phycology. Cambridge Univ. Press. 478 .

This is a good general text on the algae.

Lee/ freshwater/ salinel general/ illustrations/

Prescott, G.W. 1978. How to know the Freshwater AIgae. Wm. C. Brown Co., Dubuqua, Iowa. $293 \mathrm{p}$.

This is a good general text on identification of freshwater a lgat it also includes species occurring in inland saline 
waters. Weys are provided for identification.

Prescott/ freshwater/ saline/ general/ taxonomy/ illustrations/

Hawson, D.S. and Moora, J.E. 1944. The saline lakes of Saskatchewar. Can. J. Res. Sect.D, Zool. Sci. 22: 141-201.

This is a general review of 60 saline lakes in Saskatchewan which lists algae occurring in them. Some chemical data is presented.

Rawson/ Saskatchewan/ salinel Iake/ blue-green algael diatoml gxeen algael dinotlageliatel Chrysophyta/chemistry/generall species Iistl

Smith, G.M. 1950. The Ereshwater Algae of the United States. McGraw...Hil, N.Y., Second Edition. $719 \mathrm{p}$.

An older, but stili very useful, text on freshwater algae which includes species from saline waters.

smithl freshwater/ salinel generall taxonomy/ illustrations/

Snyder, J.M. and Wullstein, L.H. 1973. The role of desert cryptogams in nitrogen tixation. Am. Midl. Nat. 90 : $257-265$.

Several desert cryptogams and associated microorganisms were tested for potential nitrogen fixation using the acetylenereduction method. Ethylene accumulation was very low for most plants with values between 1.26 and 3.17 n moles ethylene $g^{-1}$ mal pex 15 days. The highest ethylene assays were obtained for Peltiqera rufescens (3720 n moles g ml per 10 days), Grimmia sp. (52.3 n moles $\mathrm{g}^{-1} \mathrm{~m}^{-1}$ per 15 days) ind Dermatocarpon lachneum mixed with free..Iiving Nostoc 5 pp. (162 n moles $\mathrm{g}^{-1} \mathrm{ml}^{-1} \mathrm{per} 15$ days). Free-living blue-green algae, the Nostoc sp. phycobiont of $P$. Iufescens and Azotobactes-like organisms, were implicated as the nitrogen tixers. However, the role of these organisms as the major providers of nitroger to the desert ecosystem was 4uestioned.

Snyder/ Utahl Idahol soil/ blue-green algael nitrogen fixation/

Irainor, F.R. 1978. Introductory Phycology. Wiley, New York. $525 p$.

This is a good genexal text on the algae. 
Tainor/ freshwater/ saline/ general/ illustrationsl

WiIIiams, W.D. 1981. InIand galt likes: An introduction. Hydrobiologia $81: 1-14$.

This is a good general discussion of saline lakes which large list ot citations. There is very little information on algae (diversity).

Williams/ saline/ lake/ hydrology/genexal/ review/ 


\title{
SECTION 9.1
}

\section{OTHER RELATED HABITAT PAFERS}

\author{
Cole, G.A. and Brown, R.J. 1967 The chemistry of Artemia \\ Habitats. Ecology $48: 858-861$.
}

This paper has nothing on algae. Some populations of Artemia Salina (L.) occur in high-carbonate waters and potassium-rich media where Na/K ratios are low. These habitats previously have been thought to exclude this crustacean.

Cole/ saline/ Iake/ pond/ chemistry/general/ not algael

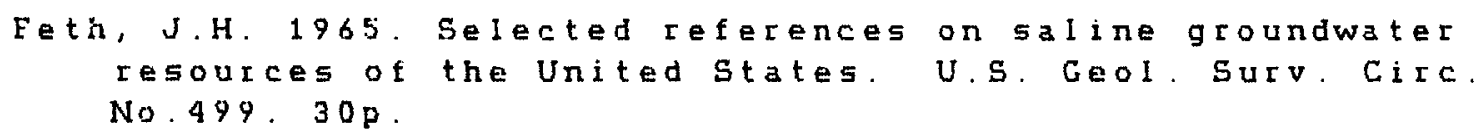

This paper is an extensive bibliography on saline groundwaters indexed by the terms "general, oil-field brines, sea-water encroachment" and by states.

Eeth/ saline/ ground water/ hydrology/ chemistry/ bibliographyl not algael

Greer, D.C. 1977 . Desertic terminal lakes. In Greer, D.C., (ed). Desertic Terminal Lakes. Utah Water Research Lab., Logan, Utah. p. 1-24.

Each terminal lake is a unique entity with its own particular characteristic but almost all have in common the ability to collect and hold soluable minerals and fluctuate greatiy in volume, area and depth. They normally contain concentrations of mineral salts which are utilized by the industrialized world. The world's largest terminal lakes are located in Asia with others tound in Atrica, Australia and North America. Most are quite fresh but some are extremely saline. Several terminal lakes are presently rising above expected levels or desiccating due to man's activities, climatic change or a combination thereof. To prevent this from happening is of great importance, hence strategies are being designed to minimize or prevent their further rise or decline.

Greer/ salinel freshwater/ lakel chemistry/ review/ environmental factors/ not algael

Peale, A.C. 1886 . Lists and analyses of the inineral springs of 
the United States. Bull. U.S. Geol. Surv. No.32, Washington, D.C. $235 \mathrm{p}$.

This paper lists the locations and the status of many saline springs in the United states, especially in the West. Nothing on a $I$ a e.

Eealel Idahol Utah/ Arizona/ New Mexicol Californial Oregonl Montana/Wyoming/ Nevada/ Colorado/ saline/ spring/ chemistry/ general/ guidebook/ not algael

Waring, G. A. with revisions by Blankenship, R. R. and Bentall, R. 1965 . Thermal springs of the United states and other countries of the world - a summary. U.S. Geol. Surv. Prof. Pap. No. 492 . $383 \mathrm{p}$.

A nultitude of hot springs throughout the world are described. Some data on chemistry are given.

Waring/ spring/ chemistry/general/ thermal habitat/guidebook/ not algael 
SECTION 10.0

KEYWORD DICTIONARY

\begin{tabular}{|c|c|c|}
\hline A i r & But t s & CuItures \\
\hline Anderson & California & Cananecki \\
\hline Andrews & Cameron & Daines \\
\hline Arizona & CarIson & Darton \\
\hline Armstrong & Carozai & Deason \\
\hline Arnal & CarpeIan & Deguire \\
\hline Avion & Carter & Diaphanous substata \\
\hline AxIer & Castenholz & Diatom \\
\hline Bane & Cave & Dinoflageliate \\
\hline Benson & Chantanachat & Distribution \\
\hline Bibliography & Chapman & Diversity \\
\hline Biochemistry & Chemistry & Drouet \\
\hline BI inn & ChIorophy I & Dunaliella \\
\hline BI $\circ \circ \mathrm{m}$ & Christensen & Durrel \\
\hline Blue-green a lgae & Chrysophyta & $E c o l \circ g y$ \\
\hline BoId & CIark & Edmondson \\
\hline BoIke & Cleave & EII is \\
\hline Borowitaka & Cliffs & Emerson \\
\hline Bot t & Cole & Environmental factors \\
\hline Bradbury & CoIlins & $E s k \in w$ \\
\hline BIitish & Colorado & Euglenophyta \\
\hline Columbia & Coombs & Evenson \\
\hline Brock & Cooper & Everet $t$ \\
\hline Brown & Cottam & Farnsworth \\
\hline Brues & Covilie & Faust \\
\hline Bryan & Crane & Feli $\mathrm{x}$ \\
\hline Busch & Crayton & Feth \\
\hline Button & Cryptophyta & Eisher \\
\hline
\end{tabular}




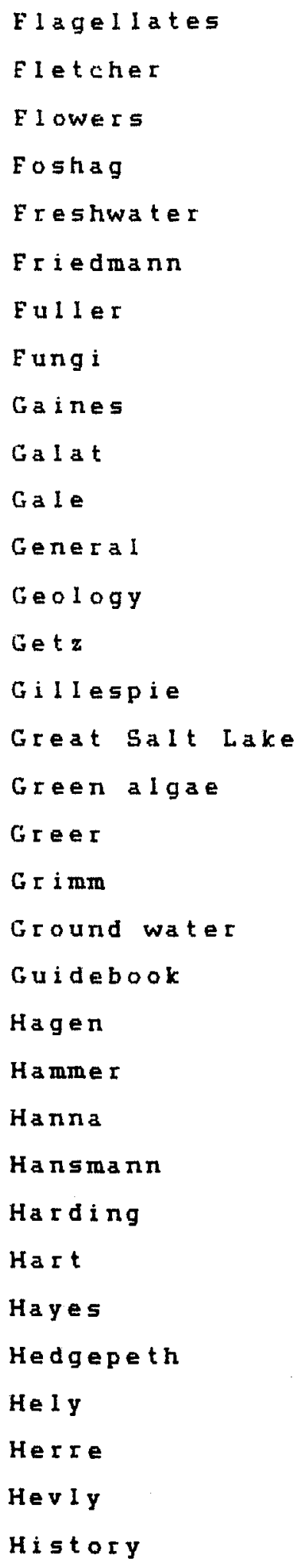

Hoham
Hood
Hostetter
Hunt
Hutchinson
Hydrology
Idaho
I Lustrations
Lnch
Johnson
Kemmerer
Kennedy
Kidd
Kimmel
Koch
Koenig
Krumbein
KuIIberg
La Rivers
Lake
Lambou
Lampkin
Langley
Lawson
Lee
LesIie
Lichens
Light
Loope
MacGregor
Laps

Markey

Martin

Mason

McCoard

McDonald

Meadow

Meigs

MeIack

Miller

Minckley

Mono Lake

Montana

Mortis

Mou-Sheng

$\mathrm{Na}$ iman

Nash

Nevada

New Mexico

Nitrogen cycle

Nitrogen fixation

Not algae

Nutrients

Ocean

Ok I ahoma

Olmsted

OIsen

oregon

Packard

Peale

Periphyton

Peterson

Pettit t

Phillips 


\begin{tabular}{|c|c|c|}
\hline Physics & snow & Waring \\
\hline PI a y a & Snowfields & Washington \\
\hline Pond & Snyder & $W \in I I s$ \\
\hline PoO 1 & Soil & West \\
\hline Porcella & Sommerfeld & Wheeler \\
\hline $\operatorname{Post}$ & Species list & White \\
\hline Pratt & Spring & Whitehead \\
\hline Prescot t & Stark & Whiting \\
\hline Proctor & Stephens & Wien \\
\hline Production & Stewart & Wi $I$ I ey \\
\hline Pyramid Lake & Stream & Wi II i ams \\
\hline Quinn & 5 t u I I & Winograd \\
\hline Rampe & Sturm & Woodbury \\
\hline Raws on & sturrock & Woods \\
\hline$R \in v i$ ew & succession & Wyoming \\
\hline Rickert & $5 w i t z e r$ & Xanthophyta \\
\hline Ri 1 Ey & Tanner & Young \\
\hline$R i v \in r$ & Taxonomy & $\mathrm{Zahl}$ \\
\hline Fobbins & Tay $10 \mathrm{I}$ & Zoology \\
\hline Rocks & Temperature & \\
\hline Rushforth & $T \in x a s$ & \\
\hline Rus 5 I 1 & Thermal habitat & \\
\hline Rychert & Thomas & \\
\hline Saline & Trace metals & \\
\hline Salt maIsh & Trainor & \\
\hline SaIton Sea & Utah & \\
\hline Saskatchewan & Utah Lake & \\
\hline $\operatorname{Schmitz}$ & Van Auken & \\
\hline SeholI & Van Denburgh & \\
\hline Shep & Van Landingham & \\
\hline $\mathrm{Sh} i \in 1 d \mathrm{~s}$ & Wade & \\
\hline Skujins & Walker Lake & \\
\hline Smith & WaIIace & \\
\hline
\end{tabular}




\section{SECTION 11.0}

I NDEX

\subsection{AUTHORS}

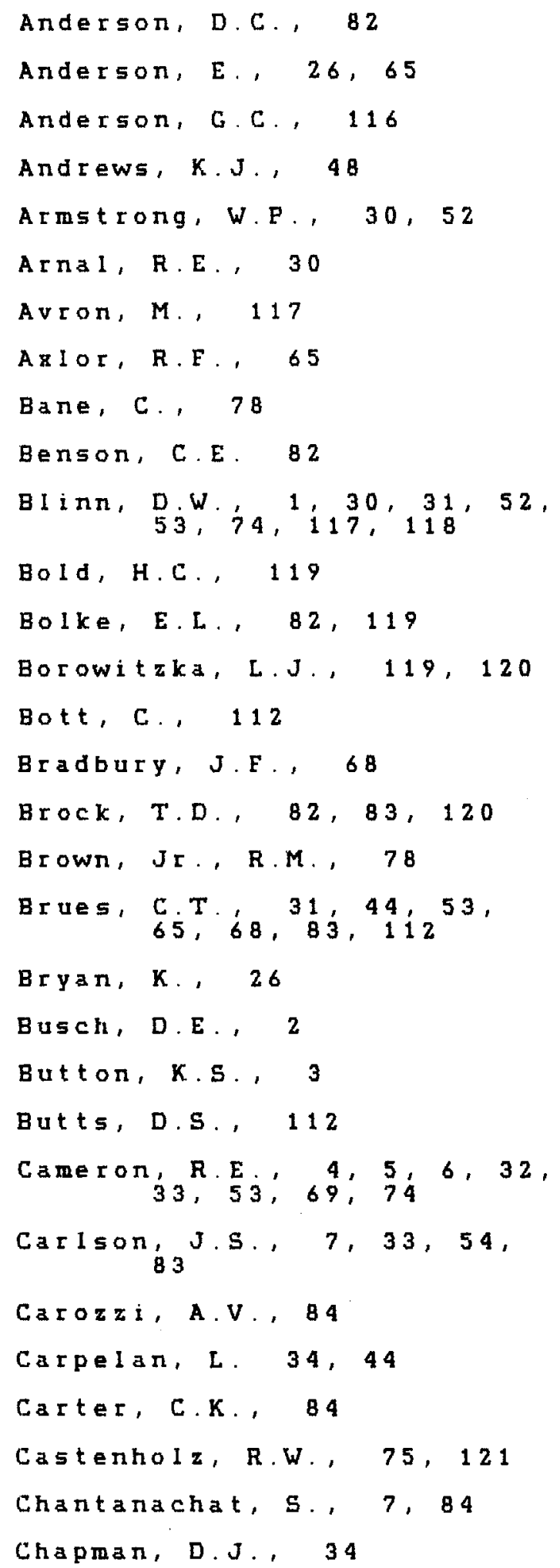

Christensen, E.M., 85

CIaIk, W.J., 85

Cleave, M.L., 85, 86

Cole, G, $54,69,7,8,8,86,34,48$,

Collins, N.C., 86

Coombs, R.E., 87

Cooper, J.B., 72, 79

Cottam, W.P., 87

Coville, F.V., 35

Crane, N.L., 9

Crayton, W.M., 9, 10

Carrecki， D.B., 11, 12, 87

Daines, L. L. , 87

Darton, N.H., 72

Deason, T.R., 79

DeGuire, M.E., 55

Drouet, F., 35,55

Durrel1, L.W., 35, 48, 55, 69

Edmondson, W.T., 35, 56, 75, B7, 122

E 11 is, M. M. , 72

Emerson, D.N., 56

Eskew, D. L., 36

Evenson, W.E., B8

Everett, L.G., $12,56,88$

Farnsworth, R. B., 13, 88, 112

Eaust, W. E., 13

Feliz, E.A., B8, B9

Feth, J.H., 126

Fisher, S.G., 13,26

Fletcher, J.E., 14

Flowers, s., 14, 49, 89, 90, 


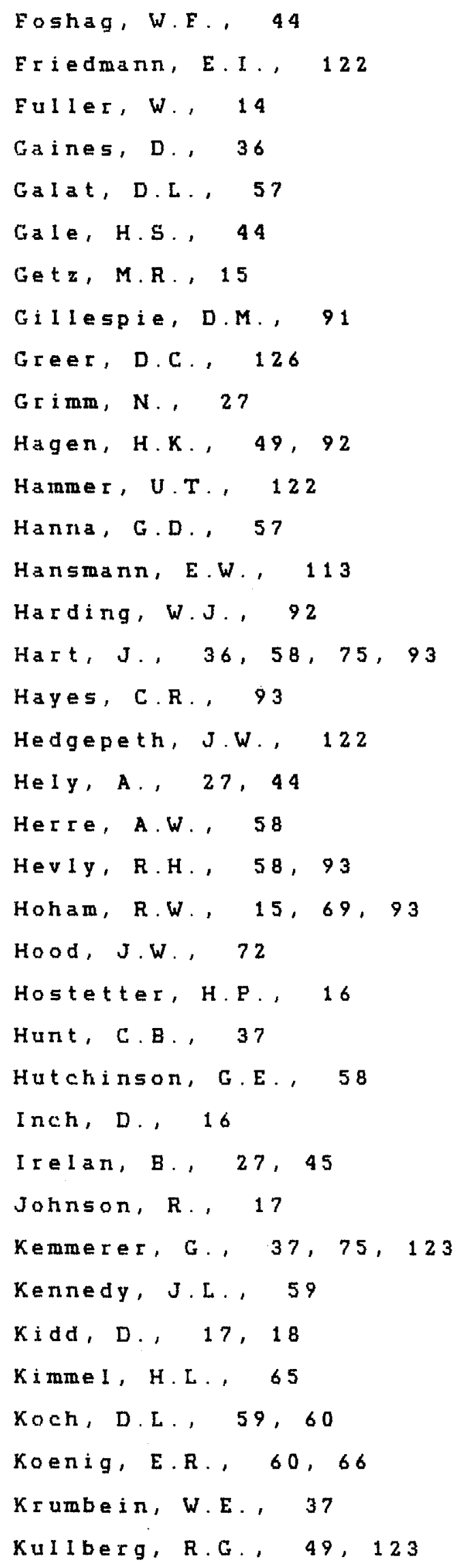

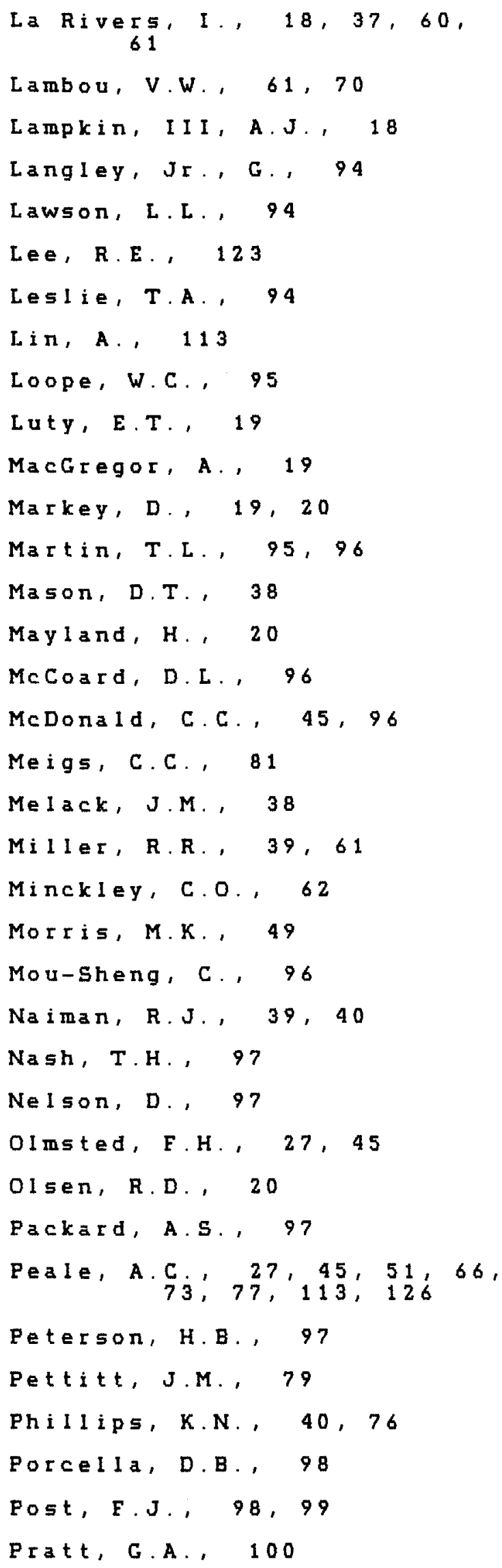




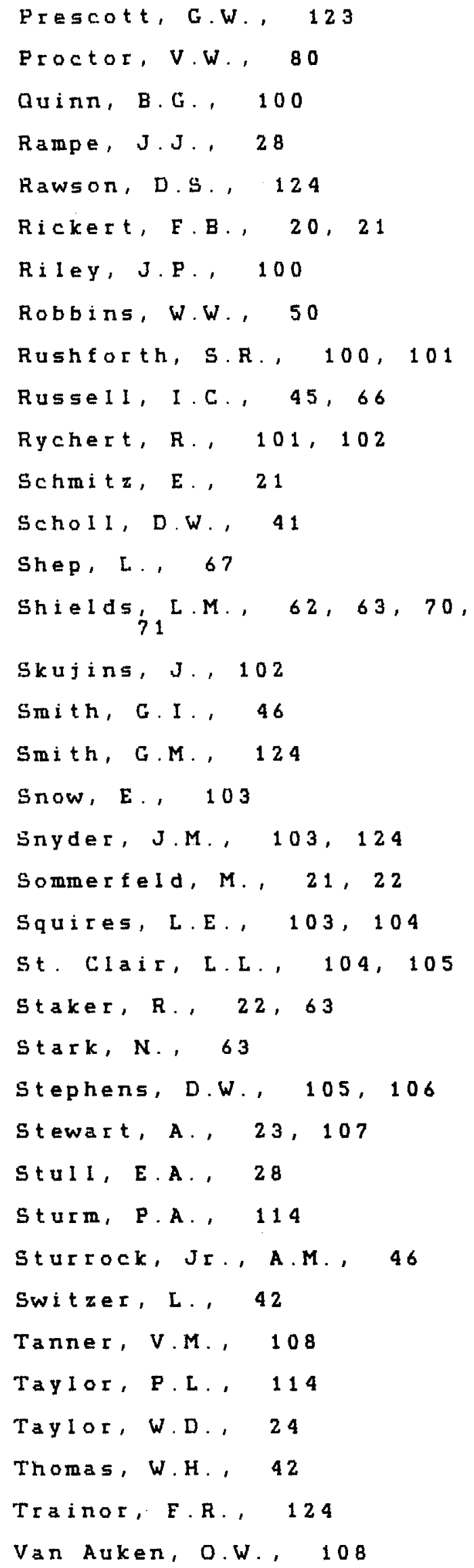

Van Denburgh, A.S., 77

Wade, W. , 24

Wallace, A., 43

Waring, G.A., 46, 127

West, N.E., 109

Wheter, S.5., 67

White, D.A., 109

Whitehead, H.C., 46, 67, 77,

Whiting, M., 109

Wien, J.D., 25

Willey, L.M., 46

Wi 11 i ams, J.E. , 76, 110

Wi 11 i ams, W.D., 125

Winograd, I.J., 47,67

Woodbury, A.M. , 25, 110

Woods, H.C., 64

Young, D.R., 43

Young, O.W, 111

Zahl， E.A.. 111 


\subsection{SELECTED KEYWORDS}

Air, 19,78

Biochemistry, 119

BI ue-green a Igae, 2-10, 12-22, 24, 25, 30-43, 48-50,53-63, $68-71,82-97,100-106,108-111,116,119-124$

Chemistry, $1,3,7-9,12,16-18,20,22,23,25-28,30,33-40$, $43-49,51,52,54-60,65-73,75-79,81-83,85-89,91,94$, $98-100,104,106,107,109,112-117,119-124,126,127$

Chrysophyta, $3-5,9,10,14-18,21,22,24,34,37,48,49$, $60,61,63,69,70,78,79,82,85,87,91-94,96,100$, $103,104,107,110,121,124$

Colorado River, $9,10,12,22,27,33,36,83,85,88$

Cryptophytz, 10, 16, 22, 24, 49, 49,61, 63, 70, 110, 121

Diatom, $1-5,7-14,16-24,30,33,34,36-40,43,48,49,54$, $56-64,68-70,75,76,78-80,82-92,94-97,100,101,103$, $104,105,107,108,110,111,116,119-121,123,124$

Dinofiagel late, $3,5,7,9,10,12,14,1 t-18,21-24,33,34$, $36,43,49,54,56,61,70,79,82,83,85,88,89,92$, $94,100,103,104,107-110,121,122,124$

Dunaliel1a, $82,117,119,120$

Euglenophyta, $3-5,9,10,14-16,18,20-24,34,37,48,49,58$, $60,61,63,69,70,79,82,91-93,96,100,101,103,107$, 110,121

Elagellates, 24,86

Geology, $30,41,44,45,66,68,72,91,121$

Great SaIt Lake, 82-84,86-91, 96-100, $105,106,108,111-114$

Green a 1 gae, $1,2,4,5-10,12-25,30-38,40,42,43,48-50$, $52-54,56-64,68-71,74-76,78-80,82-101,103-111,116-124$

Ground water, $37,47,67,126$

Hydrology, $13,26,27,44-47,67,72,125,126$

Lake, $1,3,7,11,12,15,16,18,20-24,26,28,30,34-38$, $40,41,43-46,48-50,52-61,63-70,72,74-79,81-84,86-94$, $96-100,103,105-126$

Lichens, 6, 43, 58, 70,95,97, 101, 102 
Maps, 22, 42, 63, 67, 68, 72,91

Meadow, 105

Mono Lake, $34,36,38,41,45,79$

Nitrogen cycle, 43,109

Nitrogen fixation, 6, 14, 19,20,36, 43, 71,97, 101-103, 122,124

Nutrients, $3,9,12,16,27,34,36,40,55,56,60,65,76$, $79,88,98,99,116$

Ocean, 79

Periphyton, $57,88,100,111$

Physics, 23, 26, 34, 38, 46, 58,65,68, 72, 85, 95, 107, 121

Playa, 64, 80, 91, 105

Eond, 1, 7, 8, 15, 17, 18, 20, 21, 26, 30, 31, 34, 35, 37, $42,48,52-54,56,58,61,68,69,74,75,78,80,82,86$, $87,93,104,117,118,122,126$

Pool, 5, 20, 24, 35, 40, 55, 62, 121

Pyramid Lake, 55, 57, 59, 67

Review, 6, 7, 25, 32, 34, 36, 38, 42, 45, 48, 53, 54, 56, 58, $69,75,78,79,86,87,100,101,105,110,111,121,125$, 126

River, $9,10,12,14,22,25,27,28,35,40,44,45,49,56$, $72,75,79,83,85,87,88,90,92,94,103,110,111,122$

SaIt marsh, 1

SaIton Sea, $27,30,34,40,43-46$

Snowfields, 15, 19, 35, 42, 64, 69,93

Soil, 4-7, 13, 14, 18-20, 32, 33, 35-37, 43,48, 50-53, 55, $58,61,63,64,69,70,71,74,79,82,84,88,89,95-97$, $101-103,105,109,112,120,122,124$

Species 1 ist, $1-5,7,9-11,14-25,35,43,48-50,55,57-64$, $69,70,75,79,82,84,87-94,96,97,100,101,103-105$, $107,108,110,111,116,119,121,124$

Spring, $1,5,7,8,11,12,15,16,18,26-28,31,34-37$, $44-46,48-51,53-55,58,61,65,66,68,69,72,73,75$, $77,78,83,86,91,93,96,104,110,112,113,121,123$, 126 
Stream, 1, 2, 4, 7, 9, 11, 13, 15, 17, 18, 22, 24-27, 34-37, $39,40,48,50,54,55,58,61,69,72,75,78,79,82$, $85 \ldots 88,93,100,104,110,121$

Taxonomy, 7, 11, 12, 17, 18, 20, 21, 31, 37, 53, 61, 64, 74, $79,82,84,87,94,118,119,123,124$

Temperature, $55,75,120$

Thermal habitat, $36,39,40,44,46,48,49,58,65,75,76$, $79,93,104,112,123,127$

Trace metals, 9

Utah lake, 92,94, 100, 103, 105, 108, 109

Walkex Lake, 59,60

Xanthophyta, $10,85,103,121$

$200 \log y, 7,8,12,31,33,36,40,44,53,54,56,65,67,68$, $76,79,83,88,93,94,98,106,109,112$ 
